DUE/OR/21555-T.T

DOE/OR/21555--T7

DE92 011929

\title{
EVALUATION OF THE NEED, FEASIBILITY, AND SITING OF THE MRS IN TENNESSEE
}

Draft Final Report

\author{
Contractors: University of Tennessee \\ Waste Management Research and Education Institute \\ Transportation Center \\ Energy, Environment, and Resources Center \\ Vanderbilt University \\ Oak Ridge Associated Universities \\ Institute for Energy Analysis \\ Nuclear Assurance Corporation
}

December 16,1985

\section{DISCLAIMER}

This report was prepared as an account of work sponsored by an agency of the United States Government. Neither the United States Government nor any agency thereof, nor any of their employees, makes any warranty, express or implied, or assumes any legal liability or responsibility for the accuracy, completeness, or usefulness of any information, apparatus, product, or process disclosed, or represents that its use would not infringe privately owned rights. Reference herein to any specific commercial product, process, or service by trade name, trademark, manufacturer, or otherwise does not necessarily constitute or imply its endorsement, recommendation, or favoring by the United States Government or any agency thereof. The views and opinions of authors expressed herein do not necessarily state or reflect those of the United States Government or any agency thereof. 


\section{TABLE OF CONTENTS}

\section{SUMMARY REPORT}

University of Tennessee

APPENDIX A: Spent Fuel Discharges and Additional Spent-Fuel Storage Needs Nuclear Assurance Corporation

APPENDIX B: Optimized Transportation Scheme

Nuclear Assurance Corporation

APPENDIX C: Transportation Studies (provided as separate volume) University of Tennessee

Vanderbilt University

APPENDIX D: Financial Cost Studies

Oak Ridge Associated Universities

APPENDIX E: Rod Consolidation and the MRS

Oak Ridge Associated Universities

APPENDIX F: Siting Review

Oak Ridge Associated Universities 
EVALUATION OF THE NEED, FEASIBILITY, AND SITING OF THE MRS IN TENNESSEE

Summary Report

\author{
Contractors: University of Tennessee \\ Waste Management Research and Education \\ Transportation Center \\ Energy, Environment, and Resources Center \\ Vanderbilt University \\ Oak Ridge Associated Universities \\ Institute for Energy Analysis \\ Nuclear Assurance Corporation
}

summary report prepared by

E. William Colglazier, Jr.

Director

Waste Management Research and Education Institute and

Energy, Environment, and Resources Center

The University of Tennessee

327 South Stadium Hall

Knoxville, TN 37996-0710

(615) $974-4251$

December 16, 1985 


\section{EXECUTIVE SUMMARY}

This summary report outlines the results of an independent assessment of the need, feasibility, and siting of the proposed Monitored Retrievable Storage (MRS) facility that was conducted for the state of Tennessee by a team of contractors that Included the University of Tennessee, Vanderbilt University, Oak Ridge Associated Universities, and the Nuclear Assurance Corporation. The detalled reports of this assessment are included as appendices to the summary report.

The Department of Energy (DOE) has concluded that the MRS is not absolutely necessary, but preferred, in order to manage and move spent fuel from reactors to a repository. The team has attempted to assess "need" by comparing the advantages and disadvantages of varlous systems, with and without the MRS. "Feasibility" has been assessed by comparing the technical and economic advantages and disadvantages. The team was not asked to recommend a preferred system. That choice will depend on the importance that is attached by a decisionmaker to the various criteria that are used to compare alternatives.

The five key criteria selected by the team for comparing alternate systems were: (i) economic cost, (ii) radiological risk, (iii) non-radiological transportation impacts, (iv) the likelihood of successful implementation and operation of the system, and $(v)$ the likelihood of meeting the schedule in the Nuclear Waste Policy Act.

The team compared twelve different systems and modeled the transportation impacts and risks with three repository sites and two MRS sites. In several of the cases, the team used an "Improved transport scheme," which differed from DOE assumptions in the size of transport casks and in the split of shipments by truck and rail. The team also prepared its own forecasts of spent fuel generation and reactor storage capacity in order to estimate the annual amount of spent fuel storage that is needed beyond what can be accommodated in reactor pools. The team examined the economic cost estimates of the alternate systems and the technical feasibility of rod consolidation as proposed at the MRS. The approach used by DOE in siting the MRS in Tennessee was also reviewed.

The team's key findings from its analysis of the need, feasibility, and siting of the MRS are:

(1) By using an improved transport scheme, the national transportation impacts of both the MRS and NO-MRS alternatives are comparable and much lower than DOE's original estimates. The transportation impacts on Tennessee are higher with the MRS, but not significantly so. DOE should be encouraged to examine in detail various options for improving its transport scheme.

(2) The estimated radiological risks from transporting spent fuel are very low for both the MRS and NO-MRS alternatives.

(3) The NO-MRS alternative is roughly $\$ 2$ billion cheaper than the MRS case. 
(4) The engineering and economic feasibility of fuel rod consolidation on the scale planned at the MRS has not yet been demonstrated by DOE. DOE should be encouraged to continue its support of development, demonstration, and testing on both dry and in-pool rod consolidation, to refine its systems studies on the cost-benefit analysis of rod consolidation, and to consider a fee credit for utilities that deliver consolidated fuel.

(5) The programmatic advantages of either the MRS case or the NO-MRS case inevitably involve subjective judgments. With sufficient emphasis on coordination and control, an improved NO-MRS alternative could be designed to have many of the advantages and functions as DOE's MRS.

(6) The subjective judgment of the Director of the office of Civilian Radioactive Waste Management formed the acknowledged basis for final MRS site selection. A large number of sites, including the DOE choices, would likely be technically acceptable for siting an MRS.

Comparing the alternate systems based on the original criteria, the conclusion on "need" can be summarized as follows. The second and third criteria -- reducing transportation impacts and risk -- do not significantly discriminate between the NO-MRS and MRS alternatives, provided that an improved transport scheme is used. The fifth criterion -- increasing the likelihood of meeting the schedule in the NWPA - - also does not significantly discriminate between the alternatives, presuming that the MRS case is implemented as proposed by DOE with a linkage in the schedules between the acceptance of spent fuel at the MRS and construction authorization of the repository. On the basis of cost, the first criterion, the MRS alternative is higher by about $6 \%$ of total estimated systern cost.

The fourth criterion -- improving the likelihood of successful implementation and operation of the system -- is the key criterion for DOE in justifying 1 ts preference for the MRS, even with its higher cost. This is a matter of judgment. Reasonable people can conclude that the MRS system is desirable because of the programmatic benefits perceived by DOE. Other reasonable people can conclude that a properly designed NO-MRS alternative is preferable. It is highly likely that either alternative. particularly with additional testing and development, is technically feasible. 
Introduction

The Department of Energy (DOE) has attempted to provide in its documents submitted to Congress a rigorous and credible "need and feaslbility" analysis of the Monitored Retrievable Storage (MRS) facility as required by the Nuclear Waste Policy Act.(1,2) As long as questions of safety can be satisfactorily answered, one of the key issues for determining whether any state should host the MRS is an adequate Justiffcation of its need and feasibility. This summary report outlines the results of an independent assessment of the need, feasibility, and siting of the MRS that was conducted for the state of Tennessee by a team of contractors that included the University of Tennessee, Vanderbilt University, Oak Ridge Associated Universities, and the Nuclear Assurance Corporation. The detailed reports of this assessment are included as appendices to the summary report.

\section{General Philosophy}

As DOE and the Congressional office of Technology Assessment (OTA) readily acknowledge, the MRS is not absolutely necessary in order to manage and move spent fuel from reactors to a repository. (3) "Need" can only be answered in terms of a comparison of the advantages and disadvantages of various alternate systems, with and without the MRS. The assessment of "feasibility," which ran be used to compare alternatives, is an examination of the technical, economic, and political feasibility of each system.

A set of criteria and an estimate of their relative importance is needed to compare alternate systems. Before making a comparison, the alternatives should be defined and reasonably optimized using the criterla 
and their weights. Also required is a fairly robust sensitivity analysis to take into account the effect of uncertainties and a possible shifting of the weights. Subjective judgments are involved, but the comparision should be systematic and clearly explain arguments for and against each system.

The purpose of the contractors' study was not to recommend a preferred system for managing spent fuel, but rather to examine carefully and assess the advantages and disadvantages to Tennessee and the nation of various alternatives. The contractor team compared the alternate systems according to each of several criteria. The choice of a preferred system will depend on the relative importance that is attached by a decisionmaker to the criteria. Although political feaslbility is an important aspect. the team confined itself to examining only technical and economic feasibility.

\section{Criteria}

Before selecting tentative criteria, the team reviewed the major DOE Justifications for the MRS. The DOE summary of the advantages of the MRS includes: (1) allows completion of important pre-emplacement waste mansgement activities independent of repository complexities and schedules, (i1) simplifies the design, construction and operation of above-ground facilities at the repository, (1ii) reduces overall transportation impacts, ( $i v)$ increases system flexibility and reliabllity by providing a buffer between waste acceptance and waste emplacement, ( $v$ ) minimizes at-reactor impacts of potential delays in the repository, and (vi) provides for operational storage needs of Federal portion of the waste management system. (A less bureaucratic phrasing of these possible 
advantages might be: (1) allows DOE to begin taking significant quantities of spent fuel from utilities by 1998, possibly even if the repository is delayed, (i1) demonstrates tanglble progress now and increases system flexibility by implementing a portion of the waste management system that can be made independent of uncertainties surrounilng the repository, (iii) makes bullding above-ground factlities at the repository somewhat easier, and (iv) reduces national transportation impacts.) Questions of cost and risk are also obviously important, as indicated by DOE's efforts to provide detailed information on these factors in its final documents.

The contractor team selected a tentative set of criteria that encompass the arguments used by DOE. The five key criterla for comparing alternate systems (not necessarlly in order of importance) appear to be: (i) economic cost, (ii) radiological risk to people and the environment, (iii) non-radiological transportation impacts, (iv) the likelihood of successful implementation and operation of the system, and (v) the likelihood of meeting the schedule in the Nuclear Waste Policy Act.

From the information provided by DOE, it appears that the system economic cost is likely to be somewhat higher with the MRS. Therefore, DOE has placed some weight, but not the highest weight, on this criterion. of course, all system cost estimates have considerable uncertainties. Minimizing the initial costs of the system will not necessarily minimize total costs in the long run. The system with the lowest cost if all goes well may have a large varlance due to uncertainties in factors 1 lke the operational date of a repository or technical feasibility. As OTA emphasizes, the relative costs of systems with and without an MRS must be examined under a wide range of contingencies. Therefore, it seems reasonable to make the expected value 
of system economic cost an important consideration, but not the overriding consideration. An alternate system that appears to be more expensive, however, will have to produce compensating advantages based on other criteria in order to be attractive.

DOE estimates that risks to people and the environment are likely to be small for any of the major alternate systems that are reasonably well-designed and operated. Thus, it seems that the criterla of reducing risks may not be significant in distinguishing between alternatives. The issue of risk, however, is of paramount importance to the public, and the analysis of risk must be carefully done for each system. If the expected risks of alternate systems are shown to be little different, then other criteria will be the determinants of the preferred system.

Minimizing transportation impacts nationally, measured in terms of cask-miles and trip-miles, is used as a major justification by DOE of the integral MRS option. Transportation impacts refer in part to nuisance, visibility, and perceptions, but reducing cask-miles and trip-miles also lowers transportation risk. DOE places considerable weight on this criterion, and many other analysts concur with DOE and believe that reducing transportation impacts is an exceedingly important consideration. OTA believes that it is potentially significant, but may not be as important as optimizing the last two criteria. What DOE did not do in its preliminary analysis was to examine what can be accomplished in minimizing transportation impacts without the MRS. (This omission was somewhat rectified by a revised analysis included as an appendix to the document submitted to Congress,) A credible comparision of alternatives requires examining a "no MRS" system that has been optimized to reduce transportation impacts. 
The remaining two criterla -- likel thood of successful system implementation and operation and meeting the schedule in the NWPA -- are given ,reat weight by both DOE and OTA. It is reasonable to make the last two criteria very important, but arguments in these highly subjective areas must be spelled out very carefully and be subjected to critical review when comparing alternate systems. Reaching consensus judgments on how well a system meets these two criteria may not be easy.

The five criteria selected by the team seem reasonable ones for comparing alternate systems, and all seem to be important. Several systems should be defined (based on optimization using different weights for the criteria) in order to give a feeling for the sensitivity of changes in weighting. Before discussing alternate systems that were considered by the contractor team, a discussion of the boundary conditions on the nuclear waste management system is needed.

\section{Boundary Cond1tions}

The key boundary condition is the annual amount of spent fuel storage that is needed beyond what can be accommodated in reactor pools. This supplemental storage requirement is affected by spent fuel generation and reactor storage forecasts. Therefore, a forecast must be made for the amount of spent fuel generated annually for the next twenty or thirty years. A forecast must also be made for utility at-reactor pool storage capacity, with and without rod consolidation, for the same period. These forecasts, when combined, result in an ultimate forecast of the annual amount of supplemental spent fuel storage needed -- storage outside of existing reactor pools -- which could be accommodated by additional storage (e.g., dry cask storage) at the reactor or removal of the spent 
fuel to an MRS or repository.

Critical factors affecting the forecasts must be carefully examined in order to estimate the $11 \mathrm{klihood}$ of different projections. Although the most likely forecast should be used in the first-order compariston of alternatives, the sensitivity analysis requires understanding the effect of different forecasts that have reasonable probabilities of occurrence.

Some of the technical factors that must be examined are: nuclear capacity projections, useful plant life, utility fuel cycle plans, plant capacity factors, fuel burnup, current spent fuel storage capacity, profected/planned increases in capacity, ability to increase capacity, maximum spent fuel storage capacity with and without rod consolidation, effects of burnup credit, incentives to perform consolidation, and transshipment between like reactors.

For the contractor team, the Nuclear Assurance Corporation (NAC) reviewed analyses and forecasts made by DOE and by TVA staff as well as prepared its own evaluation of future spent fuel generation and storage capacity. The team forecast of nuclear generating capacity to the year 2000 was based on reactors in operation and an evaluation of expected starting dates for reactors under construction. Beyond the year 2000, the team reference case was based on a scenario reflecting reactor orders at a rate necessary to replace existing nuclear plants at the end of their life. Replacement was projected to be with an 1,100 megawatt electric (MWe) unit, and only reactors of 400 MWe or more were replaced. (The capacity forecast increases because of replacement of small reactors by 1,100 MWe units.) Seventy-nine replacement reactors were added from 2004 through 2020 .

The team also assumed a reactor operating life of 36 years, an average 
capactly factor of $64 \%$, and a conservative estimate of fuel burn-up increases (burnup reaching an average of 43,000 MWD/MT for PWRs and an average of $36,000 \mathrm{MWD} / \mathrm{MT}$ for BWRs by 1995). Sensitivity analyses were conducted by examining three other discharge scenarlos: constant burnup at current levels, $60 \%$ capacity factor, and no new reactor orders.

Comparision of the DOE, TVA, and team reference forecasts of nuclear capactty and cumulative spent fuel discharges are given in Table 1 . The team and TVA forecasts of cumulative spent fuel discharges in the year 2000 are approximately 41,000 metric tons, which is 8,000 metric tons less than the projection used by DOE in 1 ts MRS documents. A more recent analysis by DOE/EIA now also projects 41,000 metric tons in the year $2000 .(4)$

For the projection of additional spent-fuel storage needs, the team developed two reference estimates: an unconsolidated fuel estimate and an expected consolidated fuel estimate. Like DOE, the team assumed that new reactors added beyond 2000 w1ll have adequate storage capacity to handle their needs through the time period covered by the study. The team's unconsolidated estimate is based on the maximum capacity from the Pacific Northwest Laboratory (PNL) data base; adjusted for additional data available to NAC. The expected consolidated estimate assumes an average 1.55 consolidation ratio compared with the unconsolidated case, allowing for the appropriate unconsolidated full core reserve plus an allowance of two unconsolidated reloads per reactor. An additional factor is applied for the assumption that, on average, only 90 percent of reactors w111 consolidate. The consolidation ratio also accounts for the storage of falled fuel and non-fuel bearing components. Furthermore, certain reactors are assumed not to consolidate because of specific constraints. 


\section{SPENT FUEL DISCHARGE FORECAST \\ (cumulative thousand mtu)}

\begin{tabular}{cccc}
$\begin{array}{c}\text { END OF } \\
\text { YEAR }\end{array}$ & $\begin{array}{c}\text { DOE } \\
\text { MIDCASE }\end{array}$ & $\begin{array}{c}\text { TVA } \\
\text { FORECAST }\end{array}$ & $\begin{array}{c}\text { TEAM } \\
\text { FORECAST }\end{array}$ \\
\hline 1985 & $\sim 12$ & 14 & 13 \\
1990 & $\sim 22$ & -- & 21 \\
1995 & $\sim 35$ & -- & 31 \\
2000 & $\sim 49$ & 40 & 41 \\
2005 & $\sim 65$ & -- & 50 \\
& & & \\
& & & \\
2020 & 130 & 65 &
\end{tabular}


The two team reference cases also assume that currently planned/contracted fuel shipments will take place and that on-site transfer to and from like units on the same site will be fully utilized. For the sensitivity analysis, the team has evaluated two other scenarios: one assuming no on-site transfers or shipments beyond what has already occurred, and the other including off-site transshipment between like reactors within the same utility.

The team reference estimates for needed out-of-pool storage capacity are shown along with those of DOE and TVA staff in Figure 1. As can be seen, the team estimates for a particular year are lower than those for DOE. The only consequence of this difference for the team's analysis is in the estimate of the economic benefit of the MRS system to utilities for being able to avoid the cost of additional at-reactor storage capacity.

\section{Alternate Systems}

The basic systems that need to be examined include: DOE's integral MRS option (packaging, handling, and storage), the MRS as a back-up storage option only, the MRS as a packaging and handling facility only (no long-term backup storage allowed), and the "no MRS" option. The first and third cases are distinguished because the costs and benefits will differ if the repository is delayed.

In order to judge the sensitivity to changes in the weights of the first three criteria (cost, risk, and transportation impacts), some variations are needed for each basic system. For example, minimizing costs probably requires reducing ton-miles as much as possitle and avolding duplication of expensive packaging and handling facilities. Minimizing occupational risks may entail minimizing the number of times 


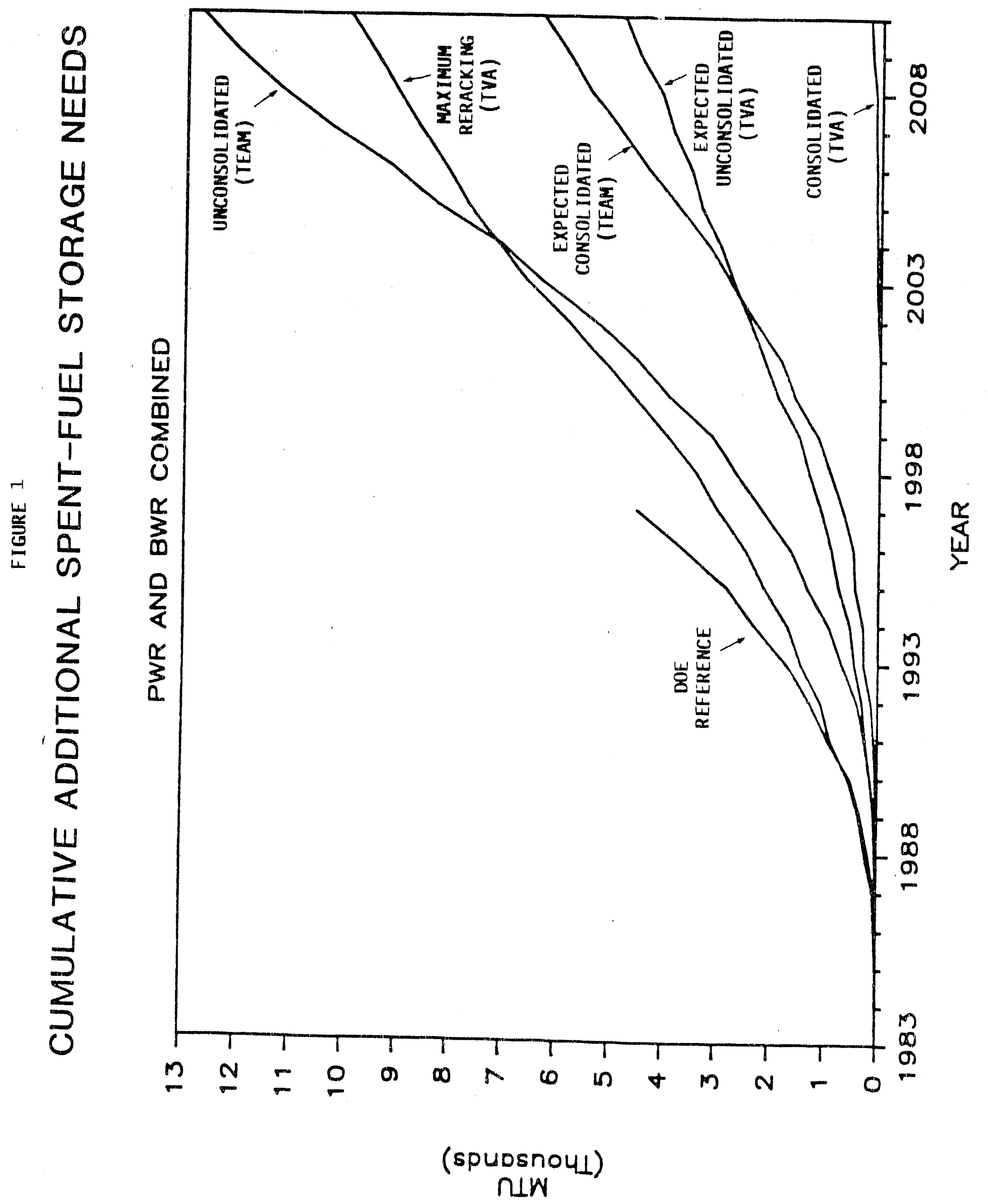


the fuel is handled, and minimizing radiation exposure to the general population may require reducing the number of casks shipped and time in transit (1,e., reducing cask-daye as much as possible). Minimizing transportation impacts requires reducing trip-miles as much as possible using techniques, when feasible, such as rod consolidation in reactor pools, maximizing the effective capacity of individual casks (using a family of casks), upgrading at-reactor transportation interfaces to maximize use of rail, and using dedicated train shipments to the MRS and/or the repository.

Twelve different systems were examined and modeled in a preliminary way by the contractor team. They include: (1) six cases of the "Integral MRS option" (four using the DOE spent fuel forecast, two using the team spent fuel forecast; two using a 70/30 ratio for plants shipping by rail versus truck to the MRS, two using an improved transport scheme; three using separate storage and transport casks, three using combined storage/transport casks); (11) two cases of "MRS as a back-up storage option only" (both using the team spent fuel forecast and an improved transport scheme; one with some rod consolidation at reactors and one with no consolidation at reactors); (11i) one case of "MRS as a packaging and handling facility only" (using the team spent fuel forecast and an improved transport scheme for intact fuel); and (iv) three cases of the "no MRS option" (one using the DOE spent fuel forecast, two using the team forecast; two with some rod consolidation at reactors and one with none; all using an improved transport scheme).

These cases provide a sufficiently diverse universe of possible systems in which to make valid comparisions and to examine the consequences of varying the weights of the criterla. For simplicity, only 
the flve cases listed in Table 2 are discussed in this paper. The key differences between these five cases, which are indicated in the table, Include assumptions about the spent fuel forecast, at-reactor consolidation, the MRS, and the transport scheme.

\section{Improved Transport Scheme}

Because reducing transportation impacts appears to be a very significant criterion, the team attempted to define an improved transport scheme that would decrease the number of shipments for both the MRS and NO-MRS systems. The team's improved transport scheme differs from DOE's assumptions in the size of the transport casks and in the split of shlpments by truck and rail. The team tried to be fairly conservative in its modifications to the DOE base case; the suggested transportation changes were felt to be relatively easy to achieve and economical. The number of shipments could be reduced even beyond the team's results with additional measures that might prove feasible.

The Nuclear Assurance Corporation examined the spent-fuel cask handling and transportation capabilities for each U. S. plant, which are the primary factors in determining the mode of transportation of spent fuel from reactors. The cask handling and transportation capabilities that were reviewed included reactor crane capacity, cask set-down area dimensions, and access utilizing the data base from PNL-5384. NAC supplemented these data with reactor and site specific data gathered from recent plant visits where appropriate. Based on current capabilities and current cask models, approximately $70 \%$ of the reactors are capable of shipping by rail.

In developing an improved transport scheme, the fundamental criterion 


\section{CASES}

$\begin{array}{lcccc}\text { CASE } & \begin{array}{l}\text { SPENT FUEL } \\ \text { FORECAST }\end{array} & \begin{array}{l}\text { AT-REACTOR } \\ \text { CONSOLIDATION }\end{array} & \text { MRS } & \begin{array}{l}\text { TRANSPORT } \\ \text { SCHEME }\end{array} \\ \text { A } & \text { DOE } & \text { NO } & \text { YES } & \text { DOE-1 } \\ \text { D } & \text { TEAM } & \text { YES } & \text { NO } & \text { TEAM } \\ \text { E } & \text { TEAM } & \text { NO } & \text { NO } & \text { TEAM } \\ \text { F } & \text { TEAM } & \text { NO } & \text { YES } & \text { TEAM } \\ \text { F }^{\sim} & \text { TEAM } & \text { NO } & \text { YES } & \text { TEAM }\end{array}$

Note: Spent fuel from western reactors is sent to the MRS in case $F$ and to the repository in case $\mathrm{F}^{\sim}$.

\section{TRANSPORT SCHEMES}

CASK CAPACITY (intact PWR/BWR fuel assemblies):

\begin{tabular}{rccc} 
TRUCK CASK & DOE-1 & DOE-2 & $\frac{\text { TEAM }}{2 / 5}$ \\
\hline 25 TON & $1 / 2$ & - & $5 / 12$ \\
40 TON & - & & \\
RAIL CASK & & & \\
\hline 70 TON & $7 / 18$ & $14 / 36$ & $15 / 34$ \\
100 TON & - & - & $24 / 56$ \\
125 TON & - & - & $31 / 72$ \\
150 TON & - & $36 / 90$ & -
\end{tabular}

Note: DOE-1 refers to the MRS siting document, DOE/RW-0023 (April 1985). DOE-2 refers to the draft MRS subnission to Congress (Nov. 1985).

PLANT ACCESS PROJECTION ( $\%$ of plants):

\begin{tabular}{llr} 
MODE & $\frac{\text { DOE }}{30 \%}$ & TEAM \\
\hline TRUCK & $70 \%$ & $13 \%$ \\
RAIL & & $87 \%$
\end{tabular}

Note: Team projection includes some intermodal shipments. 
was to utilize the largest (highest capacity) cask capable of being handled by the reactor and transported effectlvely. A famlly of truck and rail casks was chosen instead of a single cask for each transportation mode. It was assumed that the 25 ton and 40 ton cask models would be transported on the highway as legal and overweight shipments, respectively. The sizes for rall casks were chosen to be 70,100 , and 125 tons. The analysis assumed ald fuel. to be standard PWR and BWR fuel as defined by the DOE utility waste contract. No special cask or transportation mode exceptions were made for non-standard (e.g., extra long) fuel.

The team's cask capacities in terms of intact PWR and BWR fuel assemblies are given in Table 2 and compared to the DOE assumptions. In DOE's MRS siting document of April 1985, the transportation impacts in terms of cask-miles and trip-miles, with and without the MRS, were presented assuming the use of existing casks, which have capactites indicated under the heading of "DOE-1" in the table. In the DOE draft MRS document of November 1985, the assumed cask capacities were approximately doubled, which is indicated under the heading of "DOE- 2 " In the table.

DOE assumed that those reactors without rail access, which is approximately $30 \%$ of the plants, would ship by truck. In order to maximize the shipments by train, because of the larger capacity of rail casks, NAC examined various means for decreasing the percentage of shipments moving by truck. For certain reactors that currently lack rail access, short intermcidal shipments by heavy-haul vehicle or barge were assumed for transporting spent fuel to the nearest rallhead. The longest intermodal shipment ihat was assumed was 26 miles.

of the 118 reactors evaluated by $\mathrm{NAC}, 75$ reactors were determined to 
be capable of using a 125 ton cask, 25 reactors would be limited to a 100 ton cask, and four reactors would be limited to a 70 ton cask. The 125 , 100, and 70 ton casks were assumed to be shipped by roll and represent $87 \%$ of the reactors. Approximately $13 \%$ of the plants would still use truck shipments, with ten reactors using a 40 ton cask and four using a 25 ton cask.

There are several concepts which have the potential to modify the results and reduce the number of spent-fuel cask shipments even further, but these would require further investigation and analysis. These concepts include the utilization of a transfer cask, on-site transshipment, transporting the 25 and 40 ton cask on rail, the rasibility of a 150 ton cask, and the need for a 70 ton cask model. (These options are briefly discussed in the NAC report.) DOE plans to issue two procurement activities of special interest directly related to these topics. DOE plans to contract for a reactor site interface evaluation with respect to spent fuel shlpping, and plans to perform a design competition for a new generation of transportation and dual purpose (storage/transport) casks.

\section{Transportation Mode 1 Ing}

The annual transportation requirements in cask-miles, trip-miles, and ton-miles for Tennessee and the U.S. were calculated for each of the twelve cases. Actual rall and truck mileages from each reactor to the MRS or repository were utilized in the calculations. The cask capacities were defined by either the DOE or team assumptions. The differences in spent fuel forecasts had essentially no effect on annual transportation requirements because annual shipments of spent fuel to the repository were 
assumed to be 3,000 metric tons regardless of the scenarto.

Results for DOE and several team cases in terms of annual U.S. cask-miles and trip-miles, assuming that the repository is in washington and the MRS in Oak Ridge, are given in Figure 2. The analogous results for the repository in Texas are given in Figure 3 . Figures 4 and 5 give the cask-miles and trip-miles in Tennessee for shipping to the Washington repository and Texas repository, respectively.

As before, DOE-1 refers to the use of existing casks (capacities are given in Table 2) and a $70 / 30$ ratio for plants shipping by rail versus truck, DOE-2 refers to the use of larger casks (capacities are also given in Table 2) and the same split for rall and truck shipments. DOE assumes that casks w 111 be individually shipped by rall as well as by truck from reactors. In some of the DOE cases, data was not avallable for Inclusion In the figures. The team independently calculated one DOE case, "DOE-1 with an MRS," and these results are shown in the figures for comparision.

The team cases $D, E, F$, and $F^{\sim}$ all assume the use of the team improved transport scheme, which includes the family of casks glven in Table 2 and a $87 / 13$ ratio for plants shipping by rall versus truck. In addition, the team assumes that rail shipments from reactors as well as from the MRS will be in dedicated trains with five casks per train.

The team's cases $D$ and $E$ are NO-MRS cases; spent fuel is shipped directly from the reactors to the repository. Case D assumes some rod consolidation at reactors (the team's estimated consolidation scenario): case $E$ assumes no rod consolidation at reactors. Cases $F$ and $F^{\sim}$ are MRS cases, where spent $f$ uel is consolidated at the MRS. In F, spent fuel from all reactors goes to the MRS. In $\mathrm{F}^{\sim}$, only eastern reactors ship to the MRS: western spent fuel goes directly to the repository. ('To MRS cases - 







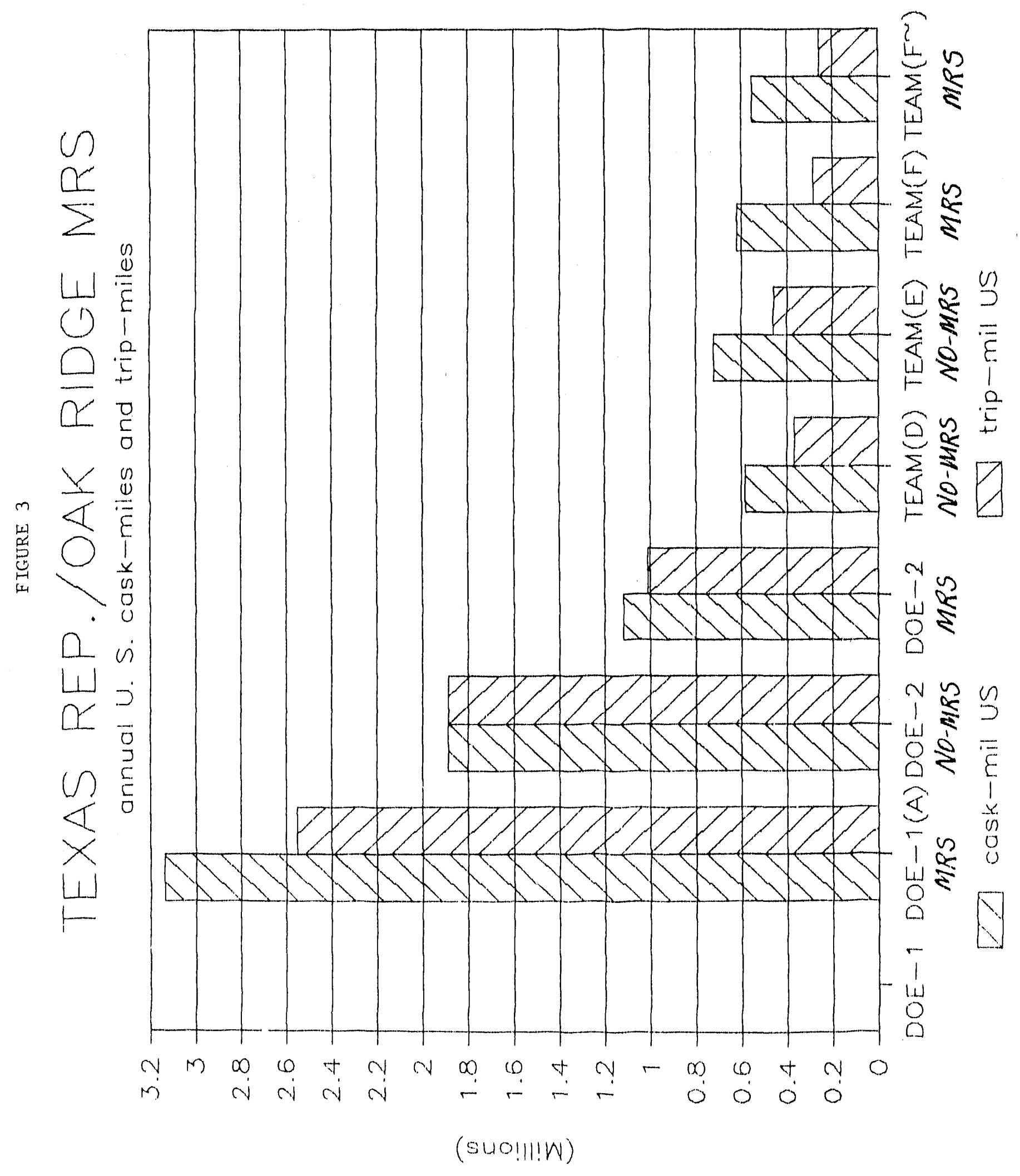




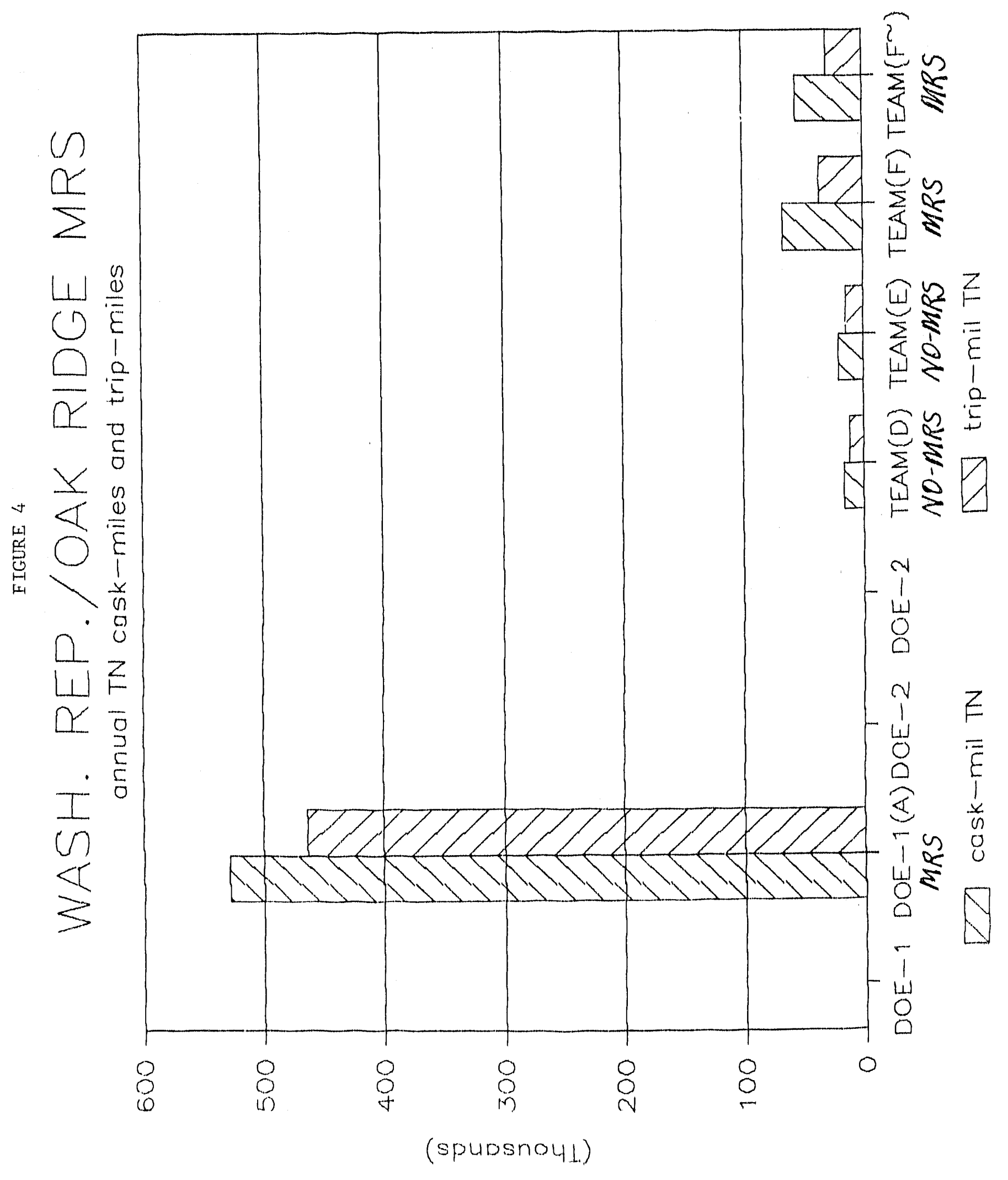




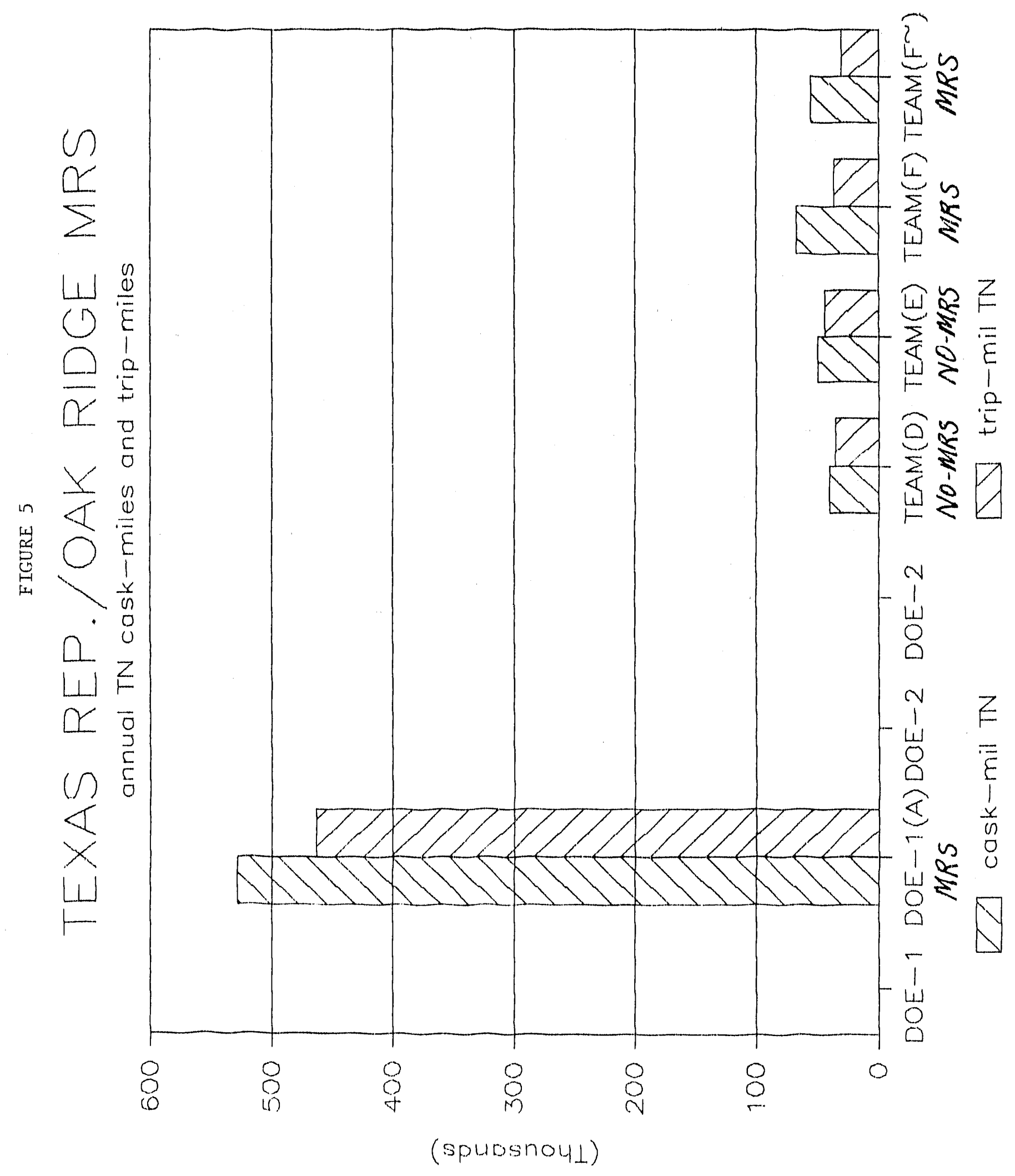




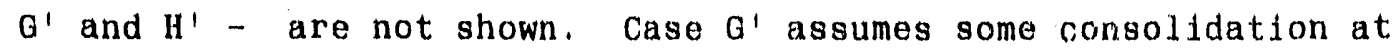
reactors as well as consolidation at the MRS. Case $H^{\prime}$ assumes no consolidation at reactors or at the MRS. In terms of cask-miles, the national transportation impacts of $Q^{\prime}$ are slightly less than $F$, and the impacts of $\mathrm{H}^{\prime}$ are roughly $20 \%$ greater.)

Upon examining the figures, one can conclude that by using an Improved transport scheme, the national transportation impacts measured in terms of cask-miles of both the MRS and NO-MRS alternatives are comparable and much lower than DOE's original estimates. The transportation impacts on Tennessee are higher with the MRS, but not significantly so. The spent fuel shipments from reactors to the repository in case $E$, or to the MRS in case F, are roughly 18 trucks and 4 trains monthly. An improved transport scheme makes sense whether or not there is an MRS.

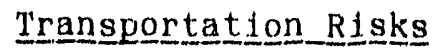

The team estimated the radlological and non-radiological transportation risks for the various cases with and without the MRS. The unit rlsk factors from RADTRAN-III were examined and reviewed in some detail. These risk factors include the contribution from accidents as well as from incident-free transportation, and they separate the risk into occupational and non-occupational components.

The team Judged that the unit risk factors were reasonable and conservative estimates, and were subsequently utilized in the team's transportation modeling. The annual transportation risks for both Tennessee and the U.S. In the case of shipping to the Nevada repository are shown in Table 3 .

The estimated transportation rlsks are small for all of the cases, but 
ANNUAL TRANSPORTATION RISK (Nevada Repository)

\begin{tabular}{|c|c|c|c|}
\hline CASE & $\begin{array}{l}\text { TN. RAD. } \\
\text { FATALITIES }\end{array}$ & $\begin{array}{l}\text { TN. NON-RAD. } \\
\text { FATALITIES }\end{array}$ & $\begin{array}{l}\text { TN. NON-RAD. } \\
\text { INJURIES }\end{array}$ \\
\hline$A(M R S)$ & .029 & .183 & 2.121 \\
\hline$D(N O-M R S)$ & .001 & .015 & .163 \\
\hline$E(N O-M R S)$ & .002 & .018 & .200 \\
\hline \multirow[t]{2}{*}{$F(M R S)$} & .002 & .057 & .613 \\
\hline & $\begin{array}{l}\text { U.S. RAD. } \\
\text { FATALITIES }\end{array}$ & $\begin{array}{l}\text { U.S. NON-RAD. } \\
\text { FATALITIES }\end{array}$ & $\begin{array}{l}\text { U.S. NON-RAD. } \\
\text { INJURIES }\end{array}$ \\
\hline$A(M R S)$ & .159 & 1.630 & 17.804 \\
\hline$D(N O-M R S)$ & .030 & .729 & 7.747 \\
\hline$E(N O-M F S)$ & .037 & .874 & 9.301 \\
\hline$F(M R S)$ & .015 & .841 & 8.737 \\
\hline
\end{tabular}


smallest for those using the improved transport scheme. The non-radiological risks are higher than the radjological risks. The estimated annual risks from transporting spent fuel are much less than that of transporting other commodities such as gasoline, chemicals, and coal.

\section{System_Cost}

DOE estimates that the net system cost of 1 ts MRS alternative is $\$ 1.5$ to $\$ 2.1$ billion greater than its NO-MRS alternattve. DOE also estimates a potential savings to utilities for avoided storage at reactors of $\$ .2$ to $\$ .5$ billion if both the repository and MRS are on time.

The team revlewed the DOE net system cost estimates and concluded that they are reasonable at this early stage of design and technology development, but there are considerable uncertainties. (The annual transportation and handling costs of any of the cases using the improved transport scheme are comparable and on the order of $\$ 5$ to $\$ 7$ million.) The DOE estimate of potentlal savings to utilities for avoided storage at reactors is high. Using the least cost options for additional on-site storage (using the team's estimate of cumulative additional spent fuel storage needs and estimates of the cost of rod consolidation in reactor pcols and the cost of storage of consolidated fuel in metal casks), the team estimates a savings of at most $\$ .1$ billion if the repository is on time and roughly $\$ .6$ billion if the repository is delayed by ten years and the MRS can accept spent fuel during t'e interim.

The DOE net system cost estimates do not include the cost of any compensation to the state, which could be on the order of several hundred million dollars. 


\section{Rod_Consoldidat 1on Feas 1 b 111 ty}

Fuel rod consolidation has the general advantage of increasing the capacity of a given container or storage space. Hence, there are possibilities for reducing the cost of spent fuel storage, transportation and ultimate disposal, and reducing the number of ton-miles and trip-miles of transportation.

DOE has only recently initlated the technology development program that would be required for an MRS-based or repository-based rod consolidation program. The team concluded that the DOE analyses and studies do not at this time support the position that rod consolidation should take place at an MRS. Rod consolidation at the MRS is simply an option. Of the operations proposed for the MRS, the consolidation operation has the greatest potential to generate accidents, unforeseen personnel exposure, by-product radioactive low-level wastes, and cost overruns. The DOE development program that has been initiated must demonstrate that these risks can be mitigated.

Many utilities already have some incentives to consolidate their own spent fuel. DOE might consider a fee credit for utilities that deliver consolidated fuel. The team felt that DOE should be encouraged to continue its support of development, demonstration, and testing on both dry and in-pool rod consolidation, and to continue to refine its systems studies on the cost-benefit analysis of rod consolidation versus shipment, storage, and/or disposal of intact fuel.

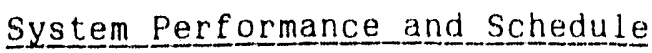

DOE's preference for the integrated MRS is based on its judgment that. the MRS system offers significant programmatic advantages. These 
perceived benefits include: decoupling the schedules for waste acceptance from utllities and waste emplacement at the repository, implementing in an early timeframe a inajor portion of DOE's waste management system which can be made independent of uncertainties surrounding the repository, increasing DOE's control and quallty assurance of spent fuel consolidation and packaglng, and providing the capabllity to accept significant quantities of spent fuel from utilities by 1998.

The programmatic advantages of either the MRS case or the NO-MRS case inevitably involve subjective judgments. Reasonable people can reach different conclusions about which alternative is preferable. With sufficlent emphasis on coordination and control, the NO-MRS case could be designed to have many of the advantages and functions as DOE's MRS. For example, consolidation and dry storage could occur at reactors (as well as at the repository) with adequate quality control and standardization. (Private companies are willing to provide consolidation services to utilities.) Buffer storage could occur at the repository to decouple waste acceptance from waste emplacement. Shipments from reactors could be accomplished with dedicated trains. The NO-MRS system, however, would not enable the front leg of the waste transportation system to be finalized before the repository is selected.

If the MRS is successfully sited, the institutional arrangements between DOE and Tennessee may be a useful precedent for similar arrangements with the repository host state. This could help reduce potential repository delays. But overall, the MRS will be little help in resolving the major technical issues in repository siting. In order to alleviate the possible concern that the MRS might become a permanent storage facility, DOE has proposed that the MRS not accept significant 
quantities of spent fuel before the repository receives a construction authorization from the Nuclear Regulatory Commission (NRC). With this strong linkage between the MRS and repository schedules, some of the flexibility benefits of the MRS may largely disappear. Utilities will still be unable to rely on DOE for a firm acceptance schedule until the repository issues are resolved to the satisfaction of the NRC. If the repository is delayed for a long period of time, the U.S. Will likely have to confront the issue of centralized monitored retrievable storage of spent fuel.

\section{MRS Site Screening Process}

The Nuclear Waste Policy Act did not require DOE to use any particular screening process in selecting a site for the MRS. The site screening philosophy used by DOE was not to reject undesirable sites, but to focus quickly on those sites which were perceived to be especially desirable.

The MRS site will need to meet certain technical criteria in order to obtain a license from the Nuclear Regulatory Commission. Because the MRS facility is based on engineered containment, however, site specific requirements are not strong discriminating factors among potential sites. A large number of sites would likely be technically acceptable for siting an MRS.

DOE used a siting analysis based in part on minimizing total trip-miles. The team concluded that this criterion does not demonstrate significant advantages in terms of transportation risk or cost. The MRS could be almost anywhere with little effect on transportation risk or $\cos \mathrm{c}$

As DOE acknowledges, the subjective judgment of the Director of the 
Office of Clvilian Radioactive Waste Management formed the basis for final site selection. The factors of potential political acceptability, community technical familiarity with nuclear activities, and potential expediency in acquisition, permitting, and construction appeared to have played an important, and probably reasonable, role in site selection.

\section{Eindings}

The team's key findings from 1 ts analysis of the need, feasibility, and siting of the MRS are:

(1) By using an improved transport scheme, the national transportation impacts of both the MRS and NO-MRS alternatives are comparable and much lower than DOE's original estimates. The transportation impacts on Tennessee are higher with the MRS, but not significantly so. DOE should be encouraged to examine in detall various options for improving its transport scheme.

(2) The estimated radiological risks from transporting spent fuel are very low for both the MRS and NO-MRS alternatives.

(3) The NO-MRS alternative is roughly $\$ 2$ billion cheaper than the MRS case.

(4) The engineering and economic feasibility of fuel rod consolidation on the scale planned at the MRS has not yet been demonstrated by DOE. DOE should be encouraged to continue 1 ts support of development, demonstration, and testing on both dry and in-pool rod consolidation, to refine its systems studies on the cost-benefit analysis of rod consolidation, and to consider a fee credit for utilities that deliver consolidated fuel.

(5) The programmatic advantages of either the MRS case or the NO-MRS case inevitably involve subjective judgments. With sufficient emphasis on coordination and control, an improved NO-MRS alternative could be designed to have many of the advantages and functions as DOE's MRS.

(6) The subjective judgment of the Director of the office of Civilian Radioactive Waste Management formed the acknowledged basis for final MRS site selection. A large number of sites, including the DOE choices, would likely be technically acceptable for siting an MRS.

Comparing the alternative systems based on the original criteria, the 
final conclusion on "need" can be summarlzed as follows. The second and third criterla -- reducing transportation impacts and risk - - do not significantly discriminate between the NO-MRS and MRS alternatives, provided that an improved transport scheme is used. The fifth criterion -- Increasing the 11kelihood of meeting the schedule in the NWPA -- also does not significantly discriminate between the alternatives, presuming that the MRS case is inplemented as proposed by DOE (with the linkage in the schedules between the acceptance of spent fuel at the MRS and construction authorization of the repository). On the basis of cost, the first criterion, the MRS alternative is higher by about $6 \%$ or so of total system cost. The fourth criterion -- Improving the likelthood of successful implementation and operation of the system - is the key criterion for DOE in fustifying its preference for the MRS. This is a matter of judgment. Reasonable people can agree with DOE and conclude that the MRS is desirable because of the programmatic benefits perceived by DOE. Other reasonable people can conclude that a properly designed NO-MRS alternative is preferable. It is highly likely that elther alternative, particularly with additional testing and development, is technlcally feasib?e.

(This summary report, for which the author assumes responsibility, is based on the work of the contractor team. The members of the team include: $M$. Bronzini, W. Colglazter, and D. Mlddendorf from the University of Tennessee; $R$. Stammer from Vanderbilt Unlversity; G. Marland, $B$. Sigmon, I. Splewak, and $C$. Whittle from oak Ridge Associated Universities; and $R$, Casper and $W$. Lee from the Nuclear Assurance Corporation. The toam would like to thank the Safe Growth Team staff and 1 ts Technical Advisory Committee, the DOE staff, and DOE contractor staff for many helpful and illuminating discussions on the MRS.) 
Notes

1. "The Need for and Feastbility of Monftored Retrlevable Storage - A Preliminary Analysis," U. S, Department of Energy, Offlce of Civilian Radloactive Waste Management, DOE/RW-0022 (Apr11 1985). "Screentng and Identification of Sites for a Proposed Monitored Retrievable Storage Facility," U. S. Department of Energy, Office of Civilian Radioactive Waste Management, DOE/RW-0023 (Apri1 1985).

2. "Monitored Retrievable Storage Submission to Congress," U. S. Department of Energy, Volume 2, preliminary draft (November 1985).

3. Office of Technology Assessment, Managing the Nation's Commercial High-Level Radioactive Waste, OTA-0-171 (March 1985). Tom Cotton, "The Monitored Retrievable Storage Facility," The Forum for Applied Research and Public Policy, (forthcoming March 1986).

4. "Spent Fuel Storage Requirements: An Update of DOE/RL-84-1," Department of Enkrgy, Richland Operations Office, DOE/RL-85-2 (October 1985). 


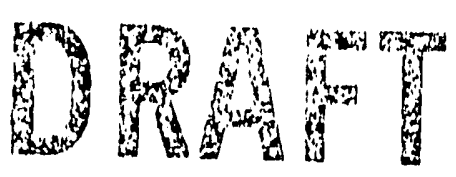

SPENT-FUEL DISCHARGES AND

ADDITIONAL SPENT-FUEL STORAGE NEEDS

October 1985

NUCLEAR ASSURANCE CORPORATION

5720 Peachtree Parkway

Norcross, Georgia 30092

Telephone: (404) 447-1144

Telex: 6827020,6827114

1225 North 23rd Street, Suite 101

Weinbergstrasse 9

Grand Junction, Colorado 81501

Telephone: (303) 245-4320

8001 Zurich, Switzerland

Telephone: (01) 470844

Telex: 57275

01985 Nuclear Assurance Corporation

Printed in U.S.A.

NAC C -85101 


\section{NOTICE}

The information contained in this report has been prepared by Nuclear Assurance Corporation based upon data obtained from sources we consider reliable and/or calculations consistent with technical principles we consider applicable. Neither Nuclear Assurance Corporation nor any individual autihor makes any warranty or representation, expressed or fimplied, with respect to the accuracy, completeness or usefulness of the information contained in this report, or assumes any responsibllity for liabllity or damage that may result from the use of any information disclosed in this report.

This report and the information it contains are proprietary to Nuclear Assurance Corporation. NAC reports are prepared especlally for clients and are furntshed to them for their use only. Except for internal use by NAC's clients, no part of this report or the information it contatns may be repro.. duced, stored in a retrieval system, or transmitted to third parties in any form or by any means, electronic, mechanical, photocopying, recording or otherwise, without the prior written consent of NAC. NAC reports and coples of any portion thereof may not be lent, sold or given to third parties without express written permission from NAC. 


\section{TABLE OF CONTENTS}

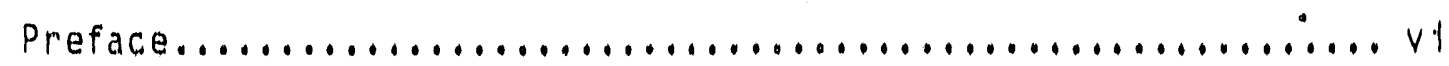

I. Spent mfuel Discharges............................ 1

A. Key Factors................................. 1

B. DOE and TVA Assumptions ....................... ?

C. Team Assumptions............................. g

D. Discussion of Reference Discharge Results.................

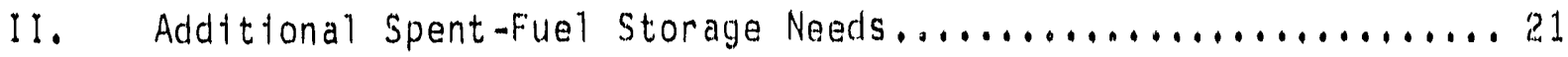

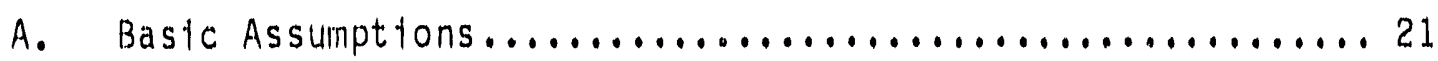

B. Compartson of Reference Addttitonal Storage Needs..........23

I11. Sensittvity Analyses on Spent-Fuel Discharges and the Need for

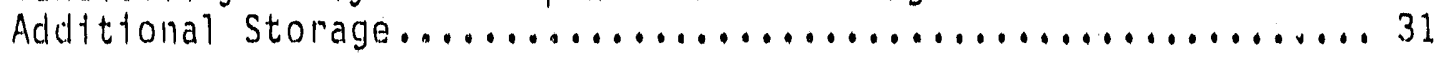

A. Team Spent..Fuel Dilscharge Estimates................... 31

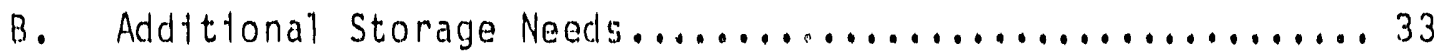

\section{Appendix}

A. Storage Capactites of Team Reference Reactors through 2000 


\section{LIST OF TABLES}

Table

1 Spent-Fuel Discharge Assumptions........................ 3

2 Team Nuclear Capacity Forecasts $\ldots . \ldots \ldots \ldots \ldots \ldots \ldots \ldots \ldots \ldots \ldots . \ldots 12$

3 Cumulattve Spent-Fuel Dil scharges (MTU) $\ldots \ldots \ldots \ldots \ldots \ldots \ldots \ldots \ldots$

4 Cumlulative Spent-Fuel Di scharges (Assemblies)................ 18

5 Cumlative Addttional SpentmFuel Storage Needs (MTU),..........25

6 Cumulattre Addttional Spent-Fuel Storage Needs (Assemblies)......28

7 Team Cumulative Spent-Fuel Discharge Sensftivity Analyses........ 3?

8 Team Cumulative Additional Spent-Fuel Storage Needs Sensitivity

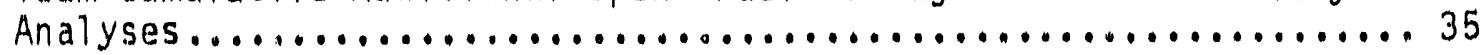

9 Team Cumlative Assembly Additional Spent-Fuel Storage Needs Sensttivity........................................... 37 


\section{LIST OF FIGURES}

Figure

Page

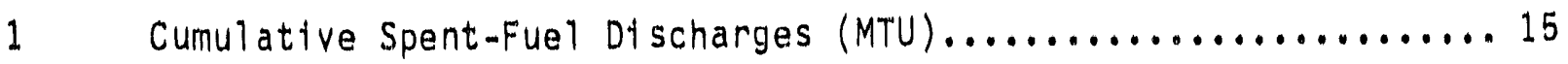

2A Cumulative Spent-Fuel Discharges (PWR Assemblites)............ 19

2B Cumulative Spent-Fuel Discharges (BWR Assemblites)........... 20

3 Cumulative Additional Spent-Fuel Storage Needs (MTU)..........26

4A Cumulative Additional Spent-Fuel Storage Needs (PWR Assemblies).. 29

4B Cumulative Additional Spent-Fuel Storage Needs (BWR Assemblies).. 30 


\section{PREFACE}

As a part of the study evaluating the impact of the location of a Monftored Retrlevable Storage (MRS) facility in the state of Tennessee, forecasts of spent-fuel generation and the need for additional storage in the U.S. have been analyzed. These forecasts were developed for the state of Tennessee as a part of a team effort including the University of Tennessee, Vanderbilt University, Oak Ridge Assoclated Universities and Nuclear Assurance Corporation (NAC). This group is hereinafter referred to as the Team. Vartous assumptions regarding the discharge of spent fuel were evaluated, and a Team set of assumptions was established as the basts for a Team reference estimate of the quantitites of spent fuel to be discharged through 2020. Additionally, scenarios of at-reactor capactty for spent-fuel storage were evaluated. These capacity scenarios were compared with the spent-fuel discharge estimate to develop Team reference estimates of additional storage needs through 2020. This report presents and discusses the analyses and compares them with previous estimates. 


\section{SECTION I \\ SPENT-FUEL DISCHARGES}

\section{A. Key Factors}

The estimation of spent-fuel discharges depends on several variables. Of these variables, five factors were determined to be key:

1. Nuclear capacity forecasts

2. Issefur service life of the plant

3. Cycle length

4. Capacity factor of the plant

5. Fuel burnup achieved

These factors were examined to determine a set of Team assumptions to be used in developing the spent-fuel discharge estimates. As a part of this evaluation, assumptions used by the Tennessee Valley Authority (TVA) and the U.S. Department of Energy (DOE) in similar analyses were examined, reviewed and compared.

Nuclear capacity forecasts represent the number and size of nuclear electrical generating units in the U.S. and the timing of their startup. This information is expressed in Megawatts or Gigawatts electrical (MWe or GWe). The possibility of additional orders must also be considered. The useful service life determines when a nuclear unit will be retired and, therefore, will no longer generate spent fuel. Cycle length refers to the interval between refuelings. Capacity factor represents the power generation performance of the unit relative to 100 percent. Fuel burnup achieved is a measure of fuel utilization.

\section{B. DOE and TVA Assumptions}

DOE and TVA have independently analyzed and developed projections of spentfuel discharges through 2020. DOE's Energy Information Administration (EIA) is directly involved in determining the DOE projections. In addition, DOE has 
obtained support from the Pacific Northwest Laboratory (PNL), which is operated for DOE by Battelle. DOE and TVA's assumptions regarding the five identified key factors were reviewed and compared. Table 1 highlights and compares their assumptions.

1. Nuclear Capacity Forecasts. TVA uses only reactors currently in operation or in the planning/construction pipeline for tis expected forecast. However, on a completion probability basis, approximately 12 GWe is never completed. This results in about 105 GWe of light water reactor capacity on 1 ine by 1995 . No additions or replacements are assumed by TVA after 1995 (i.e., no new orders). Startup of future units is adjusted according to available data on potential delays as appropriate. A 1 ist of reactors used by TVA, including start-up date, capacity and completion probability, is available in documentation transmitted by R. E. Hoskins of TVA to Florida Power and Light and Westinghouse, dated March 20, 1985. Beyond 1995, reactor retirements take place according to assumed reactor 1 ifetime, causing the GWe forecast to decrease. TVA draws upon specific reactor data available from the PNL data hase.

DOE examines several capacity scenarios--no new orders, 10w, mid and high--but relies on the mid-case as the reference basis for additional analyses regarding spent-fuel discharges. The no new orders case (similar to TVA's forecast) acts as a lower bound. The mid-case is based on the current set of known reactor projects in operation or in the pipeline, with utility start-up estimates adjusted for known potential changes as appropriate. All known reactor projects come on 1 ine by the year 2000 . Lists of the reactors operating and under construction are available in "Commercial Nuclear Power 1984: Prospects for the United States and the World," DOE/EIA-0438(84), published in November 1984, and in "Reactor-Specific Spent-Fuel Discharge Projections: 1984 to 2020," PNL-5396, issued by PNL in Apri1 1985. DOE's long-term capacity forecasts assume a continued reliance on nuclear electrical generation beyond 2000. Based on DOE's energy model, additional reactors are brought into service beginning in 2001 . The average annual 


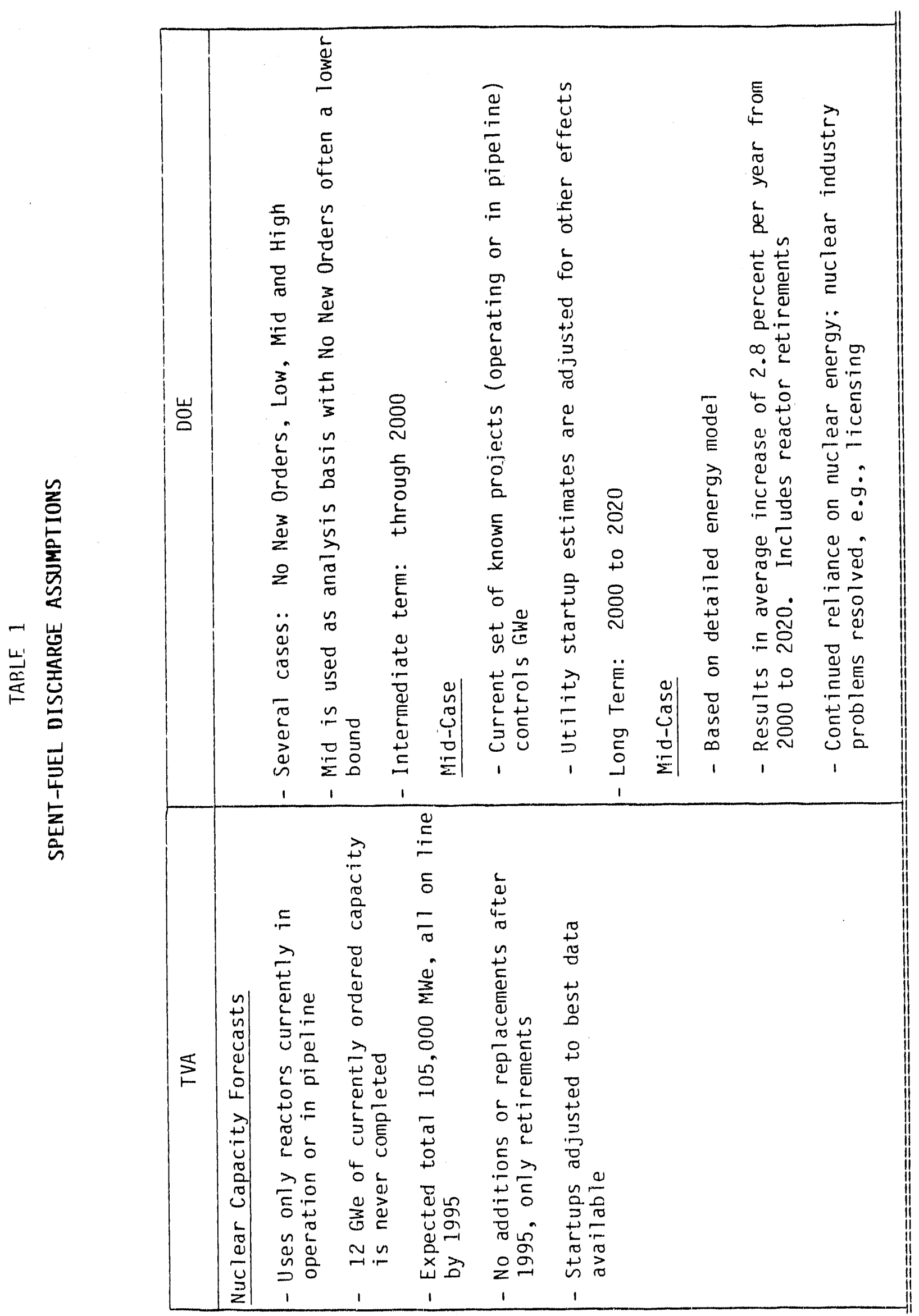




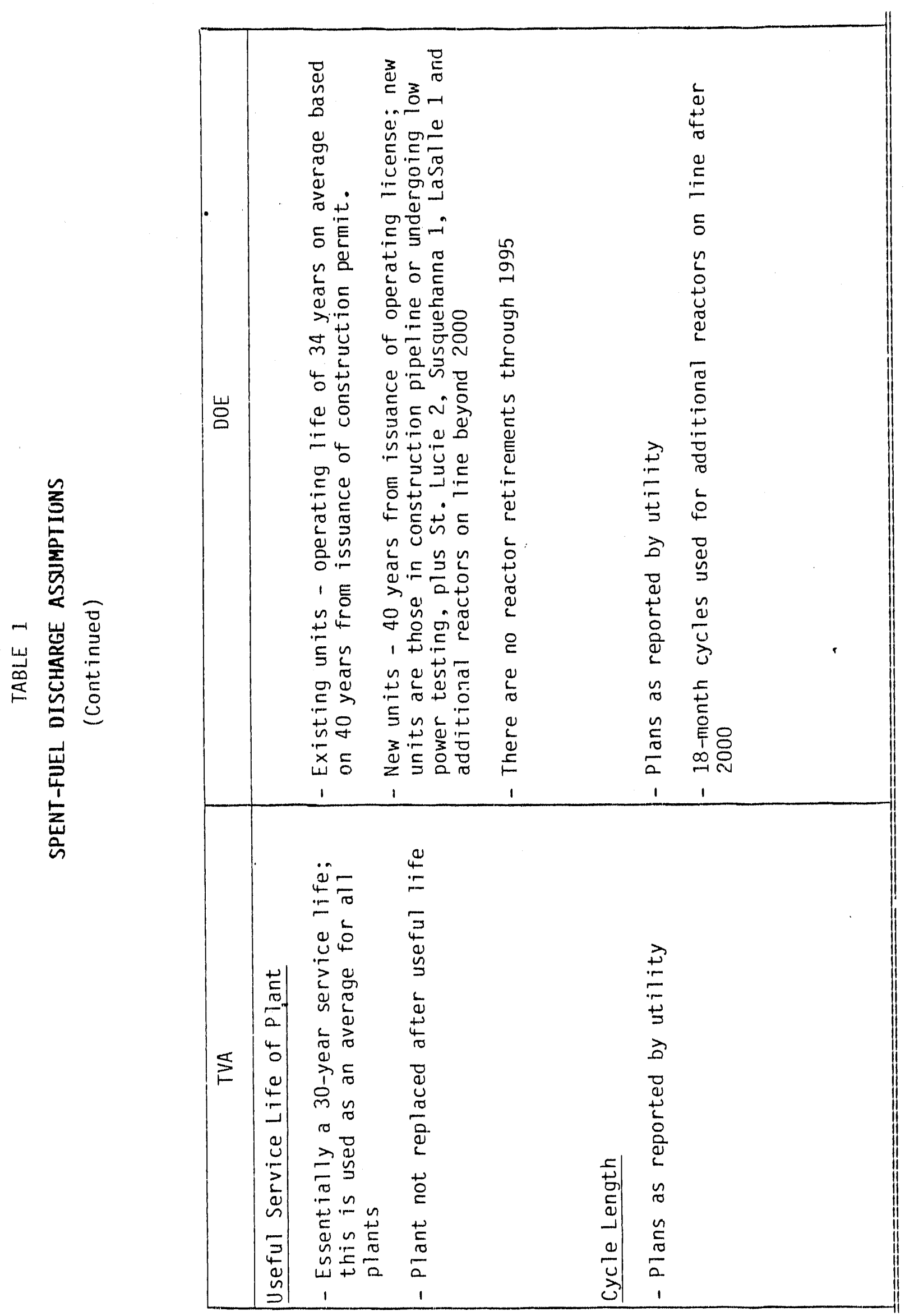




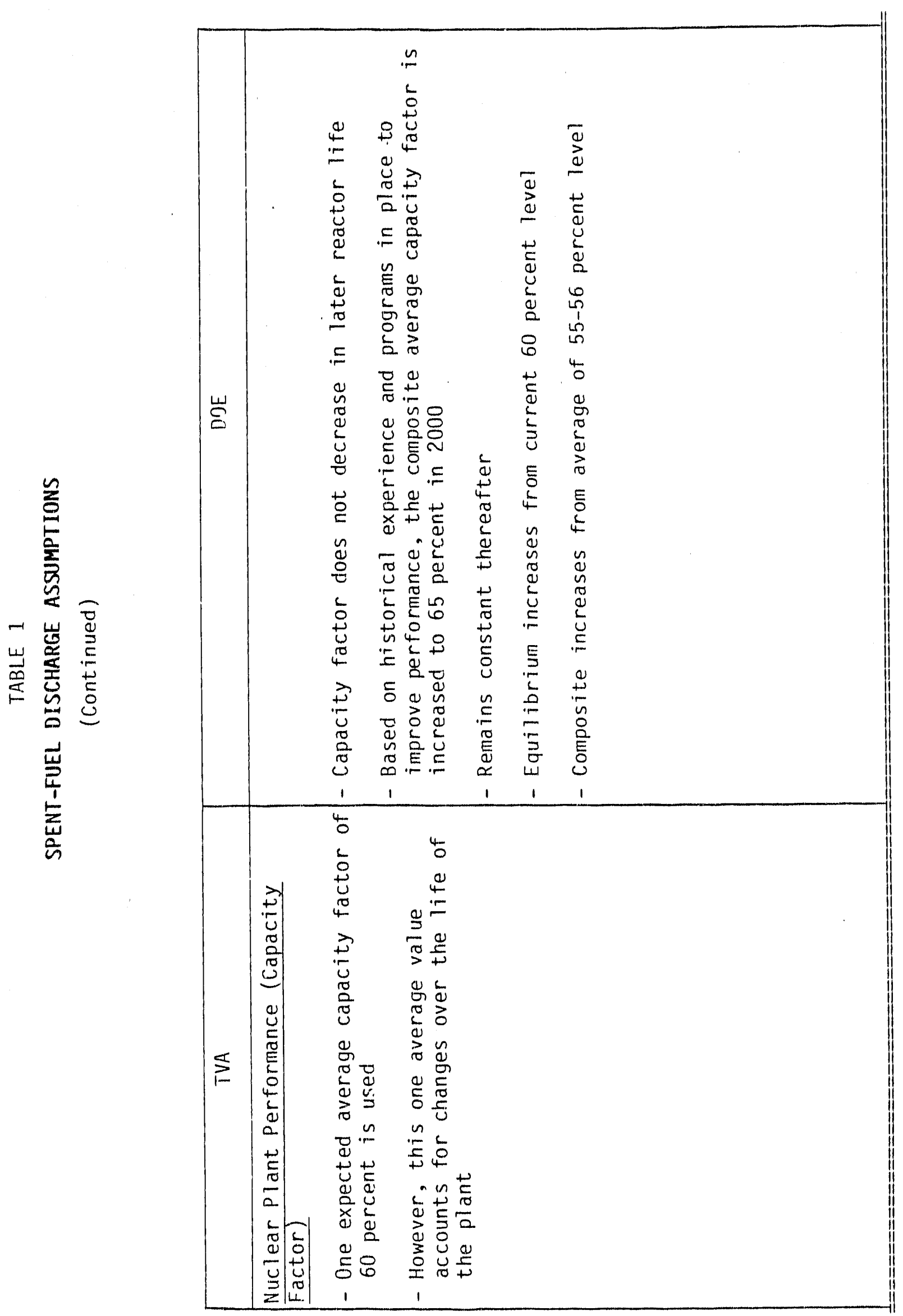




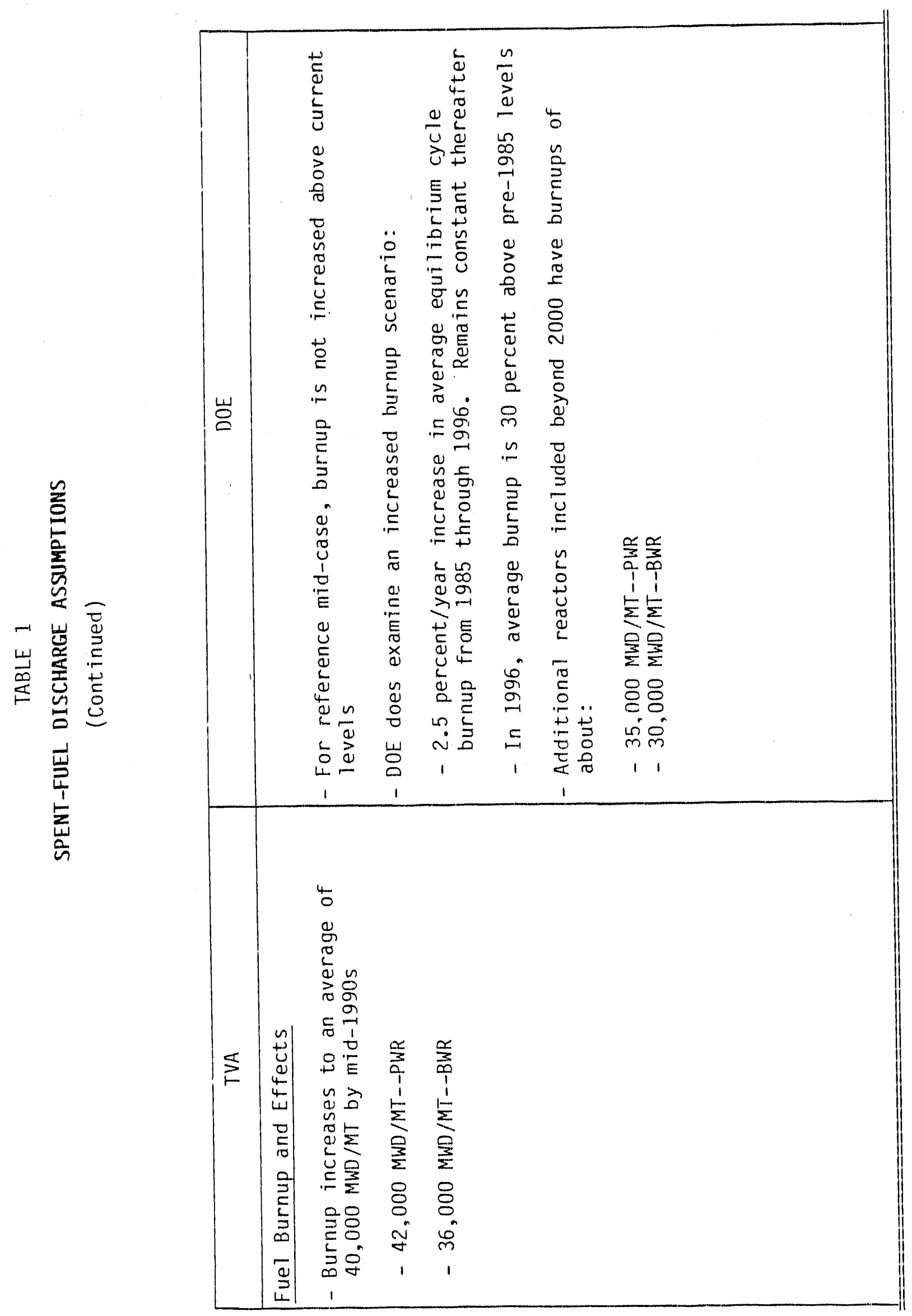


increase in nuclear GWe capactty from 2000 to 2020 in DOE's Intil-case is about 2.8 percent; this includes the influence of reactor rettrements. The following summary table shows the nuclear inactty in DOE's inid and no new orders forecasts for the given years:

$\frac{\text { Year }}{1985}$

1990

1995

2000

2005

2010

2015

2020
DOE GWe Forecast (Net)

\begin{tabular}{cc}
\hline Mrd-Case & No New Orders Case \\
\cline { 2 - 2 } 85 & 81 \\
111 & 107 \\
119 & 109 \\
122 & 108 \\
148 & 108 \\
166 & 106 \\
189 & 68 \\
212 & 49
\end{tabular}

The GWe in TVA's estimate is in general less than DOE's since: 1) TVA reaches a maximum of only about 105 GWe in 1995, and 2) as w111 be discussed subsequentiy, TVA's rate of reactor retirement is faster.

2. Useful Service Life. TVA assumes an average useful service life of 30 years for each reactor. The reactor is subsequentiy retired and not replaced. DDE uses two categortes of service 1ife. An average operating life of 34 years is used for existing units. This is based on a 40-year license from issuance of the construction permit. For new untts, a 40-year $1 i f e$ is assumed, based on a 40year license fram issuance of the operating 1 icense.

3. Cycle Length. In TVA's analysis and in DOE's reactor-specific analysts (performed by PNL), the cycle length for currently operating reactors and those under construction is essentially that reported by the utility as the planned cycle length. For the DOE additional reactors brought on 1 ine beyond 2000, an 18-month cycle is assumed by PNL, from discharge to discharge. The actual cycle length used by TVA can be varied as a function. of capacity factor 
(see below). The cycle length estimate matnly affects the timing of discharges and the amount discharged at a spectfic refueling, all else being equal; it has a minimal effect on total discharges for a given reactor over tis life.

4. Capacity factor. The total cycle capacity factor essentially measures the amount of energy generated during the cycle (from startup to startup or shutdown to shutdown) as a percentage of what could be obtained if operation was at 100 percent power during the entire cycle. TVA assumed an expected average capacity factor of 60 percent for each reactor. However, this one average value is intended to account for changes over the life of the plant (e.g., improvenents as the plant matures or reductions as the plant ages). DOE does not decrease the capacity factor later in reactor 11 fe, but does increase it from current levels. Essentially, DOE assumes an increase in composite average capacity factor from ths current level to 65 percent by 2000. Current level is assumed to be about 60 percent for equilibrium cycles, with the composite (al so including the first two cycles) currentiy at 55-56 percent. In the long term (beyond 2000), the composite capacity factor is held constant at 65 percent. Since capacity factor directly affects the amount of energy produced, the amount of fuel burned and subsequentiy discharged over a given time period is also affected.

5. Fuel Burnup. Fuel burnup, typically in units of megawatt days per metric ton uranium (MWD/MT), measures fuel utilization. The amount of fuel loaded/discharged is indirectly proportional to the burnup, all else being equal (such as cycle length and capacity factor). TVA, in its expected case, assumes that the fuel burnup will increase to an average for PWRs and BWRs combined of about 40,000 MWD/MT by the mid-1990s. PWR burnups would then reach about 42,000 MWD/MT and BWR burnups about 36,000 MWD/MT. DOE's reference inidcase assumes that burnup does not increase above cumrent levels, remaining constant throughout. DOE does consider a burnup scenario that increases average equilibrium burnup by 2.5 percent per year from 1985 through 1996 and remains constant thereafter; the 
resultant discharges from this scenarto were not used in subsequent analyses regarding the waste program. However, additional reactors brought on line by DOE after 2000 have the following approximate burnups:

$\begin{array}{ll}\text { PWR } & \text { MWD /MT } \\ \text { BWR } & 35,000 \\ & 30,000\end{array}$

\section{Team Assumptions}

A set of Team assumptions pertaining to the five key factors for the calculation of reference spent-fuel discharges through 2020 has been developed. These assumptions were arrived at from an evaluation of in-house data and review of available external documents, including TVA and DOE information. Each of the assumptions is discussed as follows:

1. Nuclear Capactty Forecasts. The bases for the Team reference capacity or expected forecast through the year 2000 is NAC's Reasonable Case Megawatt Status Report, which establishes the number of reactors, their size (MWe-net), and thetr start-up or commercial operation date. The report includes operating reactors plus reactors that are under construction or planned. It is developed from a reactor-by-reactor evaluation, through 2000, of expected operation dates for reactors not yet operating.

The following summary table compares the reference DOE, TVA and Team capactty forecasts through the years 1995 and 2000.

\section{Capactty Forecasts, GWe (Net)}

$\begin{array}{lrrr} & \frac{\text { DOE }}{119} & \frac{\text { TVA }}{105} & \text { Team } \\ 1995 & 122 & \leq 105 & 105 \\ 2000 & 105 & 105\end{array}$


Although arrived at through different assumptions, the TVA and Teain estimates are baslcally the same in terms of total GiWe. The DOE forecast is 14 and 17 Gwe higher than the Team est tmate in the years 1995 and 2000, respectively. The primary reason for these differences is the inclusion of reactors by DOE that the Team assumed would not be completed. There are 14 addltional reactors of vartous MWe ratings included by DOE.

To extend the Team nuclear capactty forecast beyond 2000, a boundtig analysts has been utflized. The lower hound is based on a no new orders/replacements scenarto. Essentially, reactors brought on line through 2000 continue to be rettred through 2020 with no replacements. In the absence of a detafled energy model, to establish an upper bound beyond 2000, the Tearn examined the DOE low, mid and high cases with respect to projected real growth in Gross Nattonal Product (GNP). Established economic forecasts from experts predtct real growth in GNP at approximately 3 percent per year. A direct correlation has prevtously been established between real GNP growth and growth in electrical generation. Therefore, if nuclear electrical generation matntalns its share of electrical generation, then nuclear capactity could be expected to increase at approximately 3 percent per year.

In fact, the DOE mid-case exhibits an almost 3 percent per year average growth rate in nuclear capacity beyond 2000. Therefore, the Team upper bound starts with the Team reference case through 2000, and it adds reactors beginning in 2001 at the same size and rate as assumed in the DOE mid-case. The Team reference case beyond 2000 was then established within the lower and upper bound. A scenario reflecting orders of nuclear reactors, at a rate necessary to replace reactors at the end of their $11 \mathrm{fe}$ (after retirement), conventently lies within these bounds. This replacement reactor scenarto defines the Team reference capactty forecast. Replacement is made with an 1,100 MWe unit, but only reactors of 400 MWe or more are replaced. As such, no replacements are made prior to 2000, a) though two reactors (Yankee 1 and Big Rock Point) with ratings 
lass than 400 MWe are assuried to be retyed before 2000. Beyond 2000 in the Team reference case, the number of reactors rematns constant, but the MWe forecast generally increases because of replacement of sinall reactors by 1,100 Mive untts. Seventyuntne replacement reactors are added from 2004 through 2020.

The three Team capactty forecasts are summarlzed th Table 2. How. ever, it is the Team expected forecast that is constdered the reference case and used in subsequent analyses. Appendtx A provides a 11st of reactors included through 2000, along with their start-up dates and MWe. Sensttivity of discharge estimates to the no new orders case will be ditscussed later.

2. Useful Service Life. The Team assumed an average reactor destgn operating 1 ife of 40 years, which is typtcal of current standards and similar to the assumption used by DOE. However, to introduce a degree of conservatism into the assumption, an average probabllity of 90 percent was applied to the 40-year design 11fe, resulting in an average 36-year operating $11 \mathrm{fe}$. Thts was used for all untts in the Team nuclear capactty estimate. At the time of retfrement, the full core is discharged.

3. Cycle Length. As TVA and DOE, for operating reactors and reactors in the construction pipeline, the Team utilizes the cycle length speciflc to each reactor according to current utility plans. These cycle lengths are actually expressed in terms of effective fuel power days; they are modified by the assumed capacity factor given below and they range typically from 12 to 24 months. For new reactors added after the year 2000 , the average cycle length is assumed to be approximately 18 months, as assumed by DOE.

4. Capacity Factor. An average capacity factor of 04 percent through 2020 is assumed by the Team for all reactors in the nuclear capacity forecast. This constant average value is based on increasing the capacity factor from its current level of about 60 percent to 65 percent in 1995 and assuming it remains constant thereafter. The 
TABLE 2

TEAM NUCLEAR CAPACITY FORECASTS

liWe (Net)

\begin{tabular}{|c|c|c|c|}
\hline $\begin{array}{l}\text { End of } \\
\text { Year }\end{array}$ & $\begin{array}{l}\text { Lower Bound } \\
\text { (No New Orders) }\end{array}$ & Reference & $\begin{array}{l}\text { Upper } \\
\text { Bound }\end{array}$ \\
\hline 1985 & 76.8 & 76.8 & 76.8 \\
\hline 1986 & 81.2 & 81.2 & 81.2 \\
\hline 1987 & 87.0 & 87.0 & 87.0 \\
\hline 1988 & 95.8 & 95.8 & 95.8 \\
\hline $1989^{\circ}$ & 100.2 & 100.2 & 100.2 \\
\hline 1990 & 103.7 & 103.7 & 103.7 \\
\hline 1991 & 104.9 & 104.9 & 104.9 \\
\hline 1992 & 104.9 & 104.9 & 104.9 \\
\hline 1993 & 104.9 & 104.9 & 104.9 \\
\hline 1994 & 104.9 & 104.9 & 104.9 \\
\hline 1995 & 104.9 & 104.9 & 104.9 \\
\hline 1996 & 104.9 & 104.9 & 104.9 \\
\hline 1997 & 104.7 & 104.7 & 104.7 \\
\hline 1998 & 104.7 & 104.7 & 104.7 \\
\hline 1999 & 104.6 & 104.6 & 104.6 \\
\hline 2000 & 104.6 & 104.6 & 104.6 \\
\hline 2001 & 104.6 & 104.6 & 111.2 \\
\hline 2002 & 104.6 & 104.6 & 116.7 \\
\hline 2003 & 104.6 & 104.6 & 121.1 \\
\hline 2004 & 103.7 & 105.9 & 124.6 \\
\hline 2005 & 102.4 & 106.8 & 129.9 \\
\hline 2010 & 77.0 & 119.9 & 160.6 \\
\hline 2015 & 57.3 & 124.4 & 182.7 \\
\hline 2020 & 38.5 & 125.4 & 187.0 \\
\hline
\end{tabular}


resultant weighted average capactty factor is about 64 percent. This is of the same order of magnttude as the TVA and DOE assumptions.

5. Fue 1 Burnup. It is assumed that by the end of 1995, burnups wi11 1 inearly increase from their current levels of about 28,000 MWD/MT (BWRs) and 32,000 MWD/MT (PWRs) to the following values:

$$
\begin{aligned}
& \text { PWR - 43,000 MWD/MT } \\
& \text { BWR - 36,000 MWD/MT }
\end{aligned}
$$

These burnup values are based on the assumption that in approxtmately 10 years, the industry should be able to achleve about 95 percent (on average) of the higher burnups for which fuel will be designed and licensed, 1.e., 45,000 MWD/MT for PWRs and 38,000 MWD/MT for BWRs. Histortcally, destgn burmups have been achleved over a comparable time period. The TVA assumption is very close to the Team estimate. It should be noted that DOE did not incorporate increased fuel burnup in tts mid-case forecast, although it was constdered in other scenarios.

\section{Discussion of Reference Discharge Results}

DOE, TVA and the Team have calculated spent-fuel discharges both on a reactorby-reactor and a global basis. Cumulattve discharges through the year 2020 in thousands of Metric Tons of Urantum (MTU) are presented on an annual basis in Table 3 and in Figure 1 for the DOE reference/mid-case, the TVA expected case, and the Team reference case. 
TABLE 3

CUMULATIVE SPENT-FUEL DISCHLARGES

1000 s of HTU

1983

1984

1985

1986

1987

1988

1989

1990

1991

1992

1993

1994

1995

1996

1997

1998

1999

2000

2001

2002

2003

2004

2005

2006

2007

2008

2009

2010

2011

2012

2013

2014

2015

2016

2017

2018

2019

2020

\section{Team Ré erence}

10.1

11.6

12.8

14.3

16.0

17.8

19.8

2.1 .5

23.4

25.5

27.5

29.4

31.3

33.3

35.0

36.9

38.6

40.8

42.4

44.3

46.3

48.0

50.3

52.3

54.7

56.9

59.2

62.1

64.9

67.1

69.8

71.8

74.3

76.5

78.7

81.3

83.5

86.2
DoE Reterence/Mid

9.9

11.1

12.4

13.8

15.5

17.5

19.6

21.9

24.2

26.7

29.3

31.9

34.6

37.3

40.1

43.0

46.0

49.0

52.0

55.0

58.1

61.4

64.8

68.6

72.7

77.4

81.9

86.4

90.4

94.5

98.7

102.9

107.2

111.5

116.0

120.7

125.4

130.3
TVA Expocted2

12.6

13.8

15.1

16.6

18.4

20.3

22.1

24.0

25.8

27.6

29.4

31.2

32.8

34.8

36.6

38.5

40.5

42.4

44.7

46.5

48.8

50.8

52.1

53.8

54.9

56.0

$5 \% .1$

50.3

59.3

60.3

61.6

63.3

64.4

65.2

65.6

$65 . \%$

65.8

1. From "Commerclal Nuclear Power 1984," DOE/ElA-0438(84). November 1984

2. From transmittal trom R. E. Hoskins, March 20, 1985 


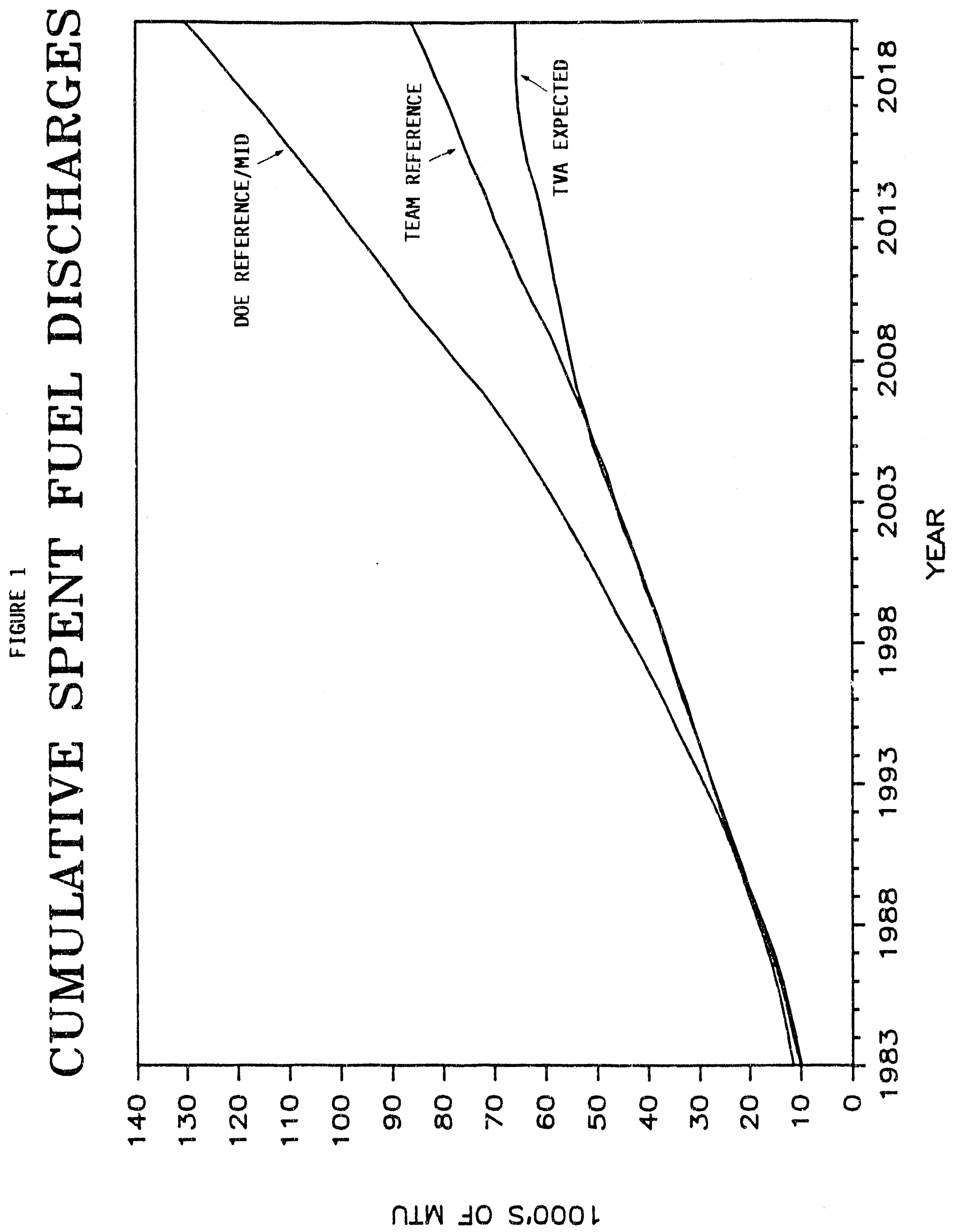


The following summary table illustrater the differences in the three cumulative discharge forecasts in the specified years:

$$
\frac{\text { Cumulative Spent-Fuel Discharges }}{1000 \text { s of MTU }}
$$

\begin{tabular}{cccccc} 
Team & $\begin{array}{c}\text { DOE } \\
\text { Reference } \\
\text { Rid }\end{array}$ & & $\begin{array}{c}\text { DOE Percent } \\
\text { Difference } \\
\text { from Team }\end{array}$ & $\begin{array}{c}\text { TVA } \\
\text { Expected }\end{array}$ & $\begin{array}{c}\text { TVA Percent } \\
\text { Difference } \\
\text { from Team }\end{array}$ \\
\cline { 2 - 3 } & 12.8 & 12.4 & $\frac{-3.1}{13.8}$ & +7.8 \\
1995 & 21.5 & 21.9 & +1.9 & 22.1 & +2.8 \\
1995 & 31.3 & 34.6 & +10.5 & 31.2 & -0.3 \\
2000 & 40.8 & 49.0 & +20.1 & 40.5 & -0.7 \\
2005 & 50.3 & 64.8 & +28.8 & 50.8 & +1.0 \\
2010 & 62.1 & 86.4 & +39.1 & 57.1 & -8.1 \\
2020 & 86.2 & 130.3 & +51.1 & 65.8 & -23.7
\end{tabular}

Although the DOE mid-case is about 3 percent below the Team estimate in 1985 , it increases at a faster rate than the Team estimate. By 1995, DOE is about 10 percent higher on a cumulative basis, with that percentage increasing to about 20 through 2000. The differences through 2000 can be attributed mainly to the inclusion of reactors by DOE that the Team assumes will not be completed, and to DOE's assumption that burnup remains constant at current levels. By 2020, DOE's estimate is over 50 percent higher than the Team estimate. This is attributable to the two factors mentioned previously, and the addition by DOE of new reactors over and above the replacement reactors assumed by the Team.

Although the TVA case is almost 8 f-rcent above the Team estimate in 1985, the difference decreases, and from the early 1990s through at least 2005 the two estimates are effectively identical. Beyond 2005, the TVA discharge estimate falls below the Team estimate and by 2020 it is almost 24 percent 1ess. This difference is due primarily to TVA's assumption that no replacement reactors come on 1 ine after the year 2000. In addition, TVA retires reactors after a somewhat shorter life than that assumed by the Team. 
The reference DOE and Team discharge estimates are al so provided through 2020 for PWRs and BWRs in Table 4. In this case, the DOE estimate is obtained from "Reactor-Specific Spent-Fuel Discharge Projections: 1984 to 2020," PNL-5396, April 1985. The assembly discharge estimates are also shown in Figures $2 a$ and $2 b$. 
TABLE 4

CUMULATIVE SPENT-FUEL DISCHARGES

Number of Assemblles

1983

1984

1985

1986

1987

1988

1989

1990

1991

1992

1993

1994

1995

1996

1997

1998

1999

2000

2001

2002

2003

2004

2005

2006

2007

2008

2009

2010

2011

2012

2013

2014

2015

2016

2017

2018

2019

2020

\begin{tabular}{|c|c|}
\hline PWR & BWR \\
\hline 14,258 & 23,317 \\
\hline 16,265 & 26,352 \\
\hline 18,069 & 28,979 \\
\hline 20,117 & 32,104 \\
\hline 22,637 & 35,364 \\
\hline 24,988 & 39,561 \\
\hline 28,064 & 43,326 \\
\hline 30,608 & 46,490 \\
\hline 33,400 & 50,255 \\
\hline 36,674 & 53,956 \\
\hline 39,313 & 58,214 \\
\hline 42,440 & 61,273 \\
\hline 45,228 & 64,862 \\
\hline 48,182 & 68,693 \\
\hline 50,647 & 71,925 \\
\hline 53,434 & 75,832 \\
\hline 56,304 & 78,165 \\
\hline 59,298 & 83,055 \\
\hline 61,985 & 85,188 \\
\hline 64,714 & 89,283 \\
\hline 67,565 & 92,827 \\
\hline 70,190 & 95,964 \\
\hline 73,482 & 100,779 \\
\hline 76,319 & 105,164 \\
\hline 79,725 & 109,644 \\
\hline 83,128 & 113,640 \\
\hline 86,433 & 118,312 \\
\hline 90,379 & 124,367 \\
\hline 94,301 & 129,890 \\
\hline 97,855 & 133,319 \\
\hline 101,729 & 138,601 \\
\hline 105,111 & 141,106 \\
\hline 108,607 & 146,170 \\
\hline 112,253 & 149,189 \\
\hline 115,833 & 152,383 \\
\hline 119,263 & 157,740 \\
\hline 122,448 & 162,230 \\
\hline 126,046 & 168,043 \\
\hline
\end{tabular}

DOE Reterence/MId 1

\begin{tabular}{|c|c|}
\hline PWR & BWR \\
\hline 14,114 & 23,157 \\
\hline 15,744 & 25,574 \\
\hline 18,054 & 28,105 \\
\hline 20,085 & 31,707 \\
\hline 22,611 & 35,206 \\
\hline 25,663 & 39,310 \\
\hline 28,755 & 43,438 \\
\hline 31,951 & 47,703 \\
\hline 35,163 & 52,467 \\
\hline 38,720 & 56,765 \\
\hline 42,314 & 61,629 \\
\hline 46,146 & 66,693 \\
\hline 49,822 & 71,643 \\
\hline 53,653 & 77,098 \\
\hline 57,701 & 82,383 \\
\hline 61,436 & 87,795 \\
\hline 65,479 & 93,035 \\
\hline 69,434 & 99,039 \\
\hline 73,247 & 103,858 \\
\hline 77.410 & 110,416 \\
\hline 81,729 & 116,381 \\
\hline 86,139 & 122,458 \\
\hline 90,916 & 129,979 \\
\hline 95,588 & 136,444 \\
\hline 100,416 & 145,934 \\
\hline 106,022 & 154,611 \\
\hline 112,791 & 164,896 \\
\hline 118,905 & 173,174 \\
\hline 124,328 & 183,377 \\
\hline 130,362 & 191,105 \\
\hline 135,773 & 198,803 \\
\hline 141,846 & 208.009 \\
\hline 147,543 & 215,754 \\
\hline 153,022 & 224,395 \\
\hline 159,076 & 233,415 \\
\hline 165,184 & 242,191 \\
\hline 171,321 & 251,031 \\
\hline 177,513 & 261,018 \\
\hline
\end{tabular}

1. From "Reactor-Specifle Spent-Fuel Discharge Projections: 1984 to 2020," PNL-5396, April 1985 


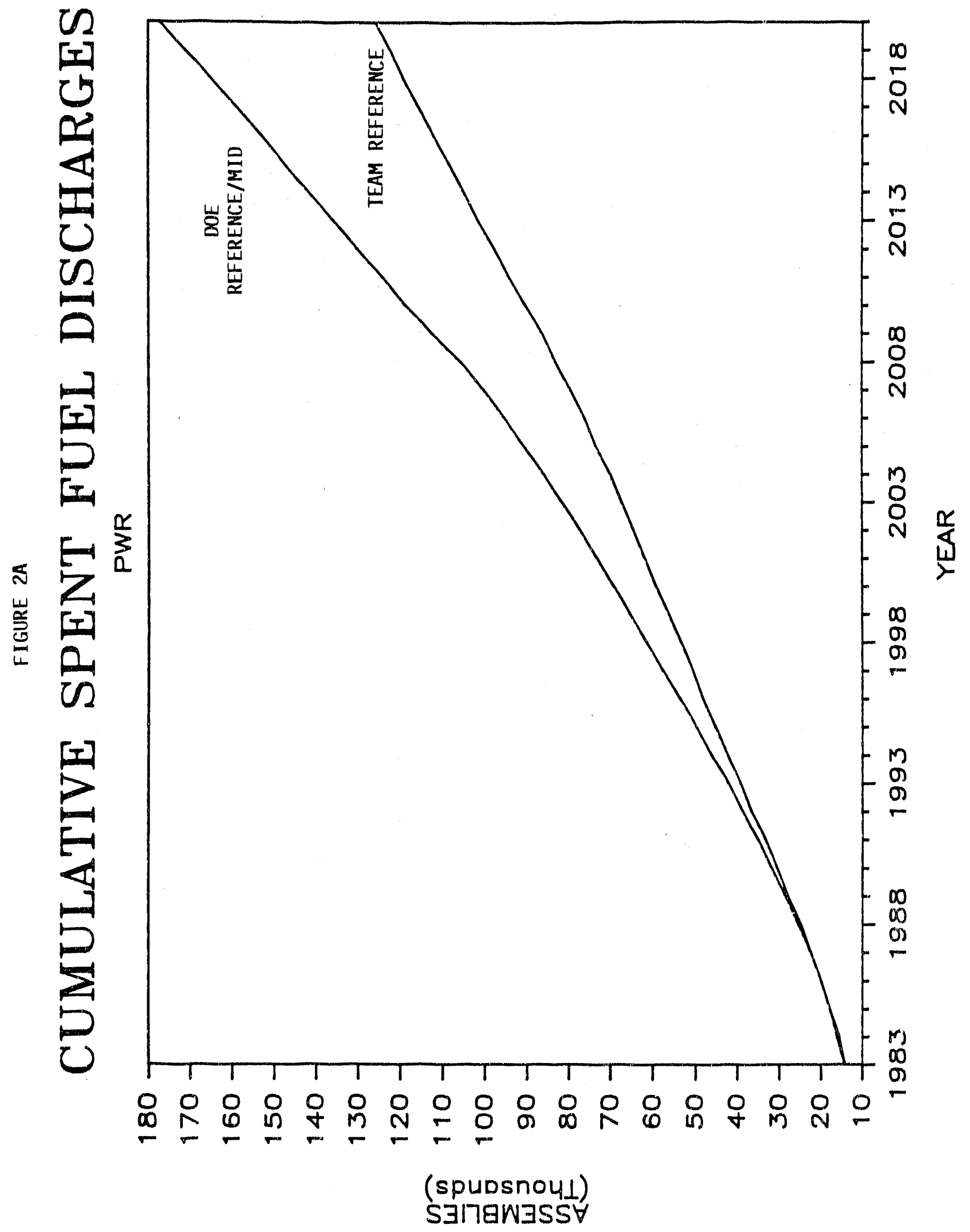




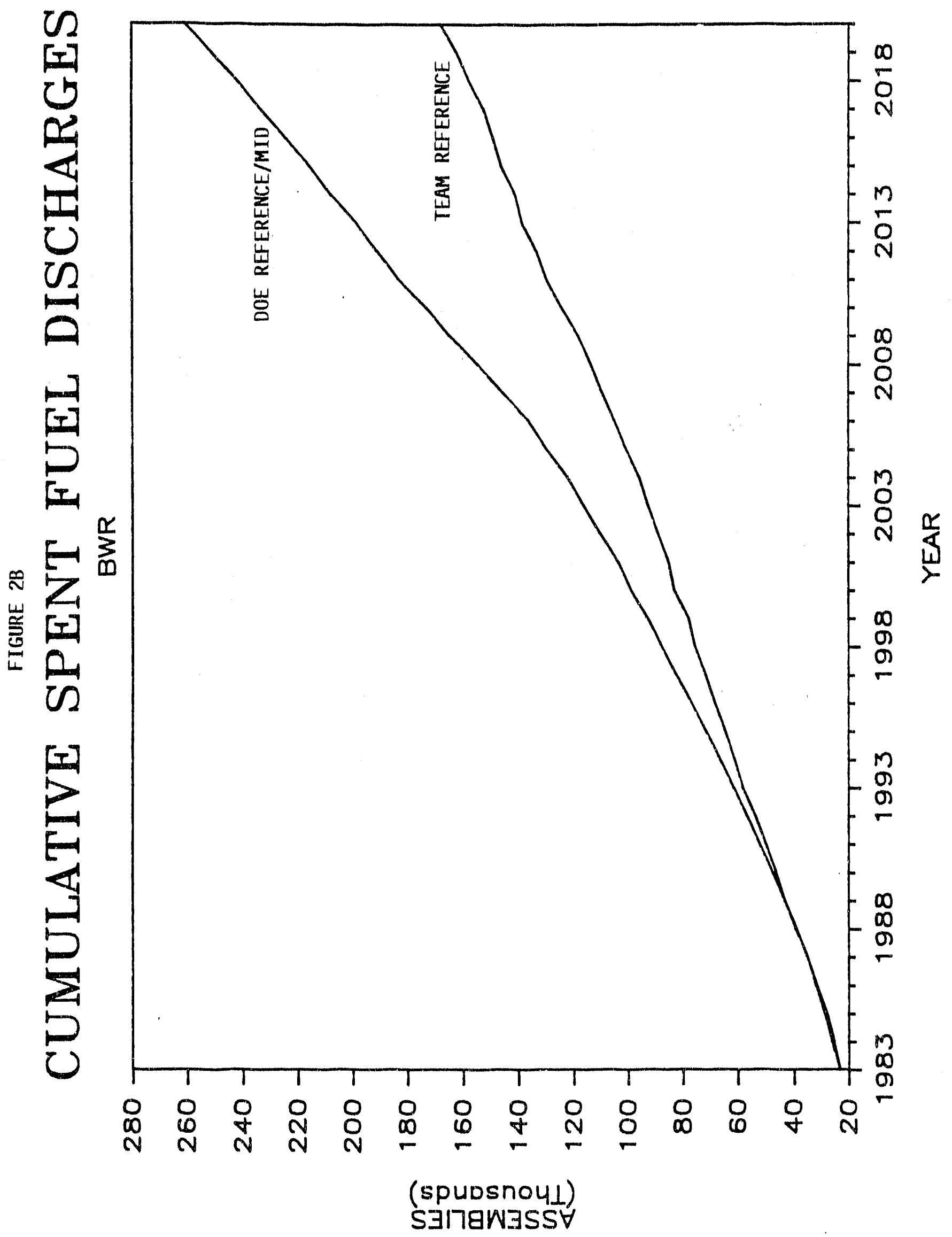


SECTION II

ADDITIONAL SPENT-FUEL STORAGE NEEDS

\section{A. Basic Assumptions}

The factors underlying the determination of additional spent-fuel storage needs are essentially:

1. The spent-fuel discharge estimates

2. The at-reactor storage capacities by reactor allowing for full-core - discharge reserve

3. Additional storage capacity based on rod consolidation

4. Extent of on-site transfers

5. Extent of transshipment

The first factor has been discussed in the previous section. Factors 2 through 5 will be discussed below with respect to the estimates made by DOE, TVA and the Team. Both DDE and the Team assume that new reactors added beyond 2000 will have adequate storage capactty to handle their needs through the time period covered by the study.

1. DOE Estimate. The assumptions and analysis for the DOE estimates of additional storage needs are documented in "Reactor-Specific SpentFuel Discharge Projections: 1984 to 2020," PNL-5396, Apri1 1985. Reactor storage capacities are based on reracking to the maximum extent possible and are extracted from "Spent-Fuel Storage Requirements," DOE/RL-84, August 1984. A fu11-core discharge reserve (FCR) is maintained for each reactor unless a common or interconnected pool is shared. In this case, only one FCR is assumed for the sharing reactors. This FCR assumption is essentially the same for the estimates of DOE, TVA and the Team, and only deviations to this assumption will be discussed, as appropriate. Rod consolidation is not considered by DOE. On-site transfers and transshipments are only included in the DOE base estimate of additional storage needs as they are currently planned by utilities. DOE does examine a case 
involving large-scale transhifiment of spent fuel between reactors of the same type (PWR or BWR) within the same utllity; however, this is considered a sensitivity case and is discussed later in the sensitivity section of this report.

2. TVA Estimate. The storage capacities assumed by TVA by reactor, and detalls regarding thetr development, are documented in the transmittal by $R$. E. Hoskins dated March 20, 1985. TVA considers a range of capacity estimates, including the current, maximum, limiting and expected/probable unconsolidated fuel estlmates plus a consolidated fuel estimate. The current and maximum estimates are essentially those from the PNL data base; the maximum implies maximum reracking for unconsolidated fuel. The expected unconsolidated fuel estimate assumes that the capacity achieved will lie between the current or stated maximum capacity and the limiting capacity, depending on reactor type and situation (e.g., structural limitations). The consolidated fuel estimate assumes a 1.7 to 1.8 consolidation ratio compared with the expected unconsolldated case, allowing for an unconsolidated FCR. These two cases, the expected unconsolidated and the consolidated, are used in this report as TVA's base reference capacities. These reference capactties are the basis for TVA's associated, reference additional spent-fuel storage needs. The TVA maximum reracking (unconsolidated) case is included for comparison purposes. TVA does not consider future on-site transfers or transshipment, but, like DOE, does include the limited number of shipments already planned by specific utilities.

3. Team Estimate. The Team developed two reference estimates: an unconsolidated fuel estimate and an expected consolidated fuel estimate. The Team's unconsolidated estimate is based on the maximum capacity from the PNL data base, adjusted for additional data available to NAC. The expected consolidated estimate assumes an average 1.55 consolidation ratio compared with the unconsolidated case, allowing for the appropriate unconsolidated FCR plus an allowance of two unconsolidated reloads per reactor. The reload allowance takes account of the spent-fuel cooling necessary prior to consolidation. 
An additional factor is applied for the assumption that, on average, only 90 percent of reactors will consolidate. The consolidation ratto also accounts for the storage of falled fuel and non-fuel bearing components. Furthermore, certatn reactors are assumed not to consolidate because of spectfic constraints. The two reference capacity estimates are shown by reactor in Appendix $A_{\text {. }}$ The Team reference cases for the definition of additional fuel storage needs assume that currently planned/contracted fuel shipinents will take place and that on-site transfer to and from like units on the same site will be fully utilized. This on-site transfer is in addition to the standard assumption on sharing common or interconnected pools. The planned shipments account for fuel being returned to reactor sites from the West Valley reprocessing site (to Ginna, Point Beach and Oyster Creek) and from the GE Morris site (to Point Beach). Also accounted for are shipments from reactor sites to the Morris site (from Cooper and Montfcello) and to the Idaho National Engineering Laboratory (INEL) from Surry as a part of a dry storage cask demonstration program. In addition, modular dry storage plans at Robinson (NUHOMS) and dry cask storage at surry are accounted for. The Tearn has evaluated two other scenarios: one assuming no on-site transfers or shipments beyond what has already occurred, and the other including transshipment between like reactors (PWR or BWR) within the same utility, along with the other reference case assumptions. These latter two scenartos are discussed further in the sensitivity section of this report.

\section{B. Comparison of Reference Additional Storage Needs}

The following reference estimates of additional spent-fuel storage needs are compared:

- DOE reference

- TVA maximum reracking (unconsolidated)

- TVA expected unconsolidated

- TVA consolidated

- Team unconsolidated

- Team expected consolidated 
Using the discharge data from Section I and the storage capactites deftned above, estimates of cumulative additional spent-fuel storage needs were deftned through the year 2010 for the vartous alternattves, as posstble. These are given in Table 5 and Flgure 3. The following summary table compares the results in flve-year increments. The year 1997 is al so shown since tt is the last year avallable for the DOE estimate and represents the amount of fuel to be stored prior to 1998, when DOE should begin accepting spent fuel.

\section{Cumulative Additional Spent-Fuel Storage Needs (MTU)}

(Reference Cases)

\begin{tabular}{|c|c|c|c|c|c|c|}
\hline & \multirow{2}{*}{\multicolumn{4}{|c|}{ Maylmon }} & \multirow{2}{*}{\multicolumn{2}{|c|}{ Team }} \\
\hline & & Maxlmum & & & & \\
\hline & $\begin{array}{c}\text { DOE } \\
\text { Reference } \\
\end{array}$ & $\begin{array}{c}\text { Reracklng } \\
\text { Unconsollidated } \\
\end{array}$ & $\begin{array}{c}\text { Expected } \\
\text { Unconsoll dated }\end{array}$ & Consoll dated & Unconsoll dated & $\begin{array}{l}\text { Expoctad } \\
\text { Consolldated }\end{array}$ \\
\hline 1985 & 0 & 23 & 0 & 0 & 0 & 0 \\
\hline 1990 & 544 & $578(+6.3)^{*}$ & $147(-73.0)$ & $0(-100)$ & $163(-70.0)$ & $48(-91.2)$ \\
\hline 1995 & 2,841 & $2,141(-24.6)$ & $758(-73.3)$ & $0(-100)$ & $1,343(-52.7)$ & $459(-83.8)$ \\
\hline 1997 & 4,536 & $2,993(-34.0)$ & $1,085(-76.1)$ & $0(-100)$ & $2,165(-52.3)$ & $685(-84.9)$ \\
\hline 2000 & - & 4,614 & 1,908 & 1 & 3,939 & 1,604 \\
\hline 2005 & $m-$ & 7,714 & 3,343 & 113 & 8,287 & 3,778 \\
\hline 2010 & -- & 9,980 & 4,860 & 241 & 12,754 & 6,366 \\
\hline $\begin{array}{l}\text { Year of } \\
\text { FIrst Noed }\end{array}$ & 1986 & $\begin{array}{c}1983 \text { (Only } 4 \\
\text { MTU) Otherwlse } \\
1985\end{array}$ & $\begin{array}{c}1986 \text { (Only } 1 \\
\text { MTU) Otherwlse } \\
1988\end{array}$ & 2000 & 1988 & 1989 \\
\hline
\end{tabular}

The TVA and Team estimates through 1997 range from 34 to 100 percent below the DOE reference case. The differences are attributable to lower discharge estimates and the various scenarios with larger storage capacities. The first. need for additional storage also varies substantially depending on the scenarto selected.

The above comparisons refer to reference case additional storage needs in terms of MTU for both PWRs and BWRs combined. The following discussion will compare results in terms of cumulative number of assemblies for PWRs and BWRs separately. Since TVA has not provided conclusions in these terms, only the DOE and Team estimates will be discussed further.

* Percent difference from DOE reference 
TABLE 5

CUMULATIVE ADDITIONAL. SPENT-FUEL STORAGE NEEDS

REFERENCE CASES

(MTU - PWR and QWR Comblned)

1983

1984

1985

1986

1987

1988

1989

1990

1991

1992

1993

1994

1995

1996

1997

1998

1999

2000

2001

2002

2003

2004

2005

2006

2007

2008

2009

2010

TVA 2

$\begin{array}{cc}\text { MaxTmum } & \text { Expected } \\ \text { Reracklng } & \\ \text { Unconsolldated Unconsolldated Consolldated }\end{array}$

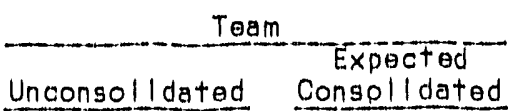

Refereno Uncomsoll dated consol

23

59

89

240

367

578

909

949

1,292

1,734

2,326

2,841

3,650

4.536

-

$-$

$--$

$-$

$-$

$--$

$-$

$-$

$--$

$-$

$-$

$-$

$--$
1,090

1,465

1,717

2,141

2,493

2,993

3,400

3,987

4,614

5,253

5,891

6,607

7,182

7,714

8,134

8,615

9,079

9,509

9,980

0

0

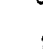

1

48

78

147

246

314

464

558

758

901

1,085

1,320

1,524

1,908

2,169

2,437

2,736

3,000

3,343

3,554

3,910

4,137

4,552

4,860

0
0
0
0

0

0

0

0

0

0

0

0

0

$$
0
$$

0

0

0

0

1

8

62

87

87

113

113

130

130

206

241
Unconsolldated $\frac{\begin{array}{c}\text { Expected } \\ \text { Conspllidated }\end{array}}{0}$

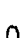

0

0

0

0

0

13

$\begin{array}{rr}48 & 13 \\ 163 & 48\end{array}$

26591

$415 \quad 141$

$695 \quad 282$

$942 \quad 301$

$1,343 \quad 459$

$1,664 \quad 500$

$2,165 \quad 685$

$2,666 \quad 921$

$3,116 \quad 1,170$

$3,939 \quad 1,604$

$4,577 \quad 1,870$

$5,380 \quad 2,341$

$6,325 \quad 2,784$

$7,134 \quad 3,202$

$8,287 \quad 3,778$

$9,167 \quad 4,367$

$10,280 \quad 4,898$

$11.251 \quad 5,449$

$12,065 \quad 5,890$

$12,754 \quad 6,366$

1. From "Reactor-Speclf Ic Spent-Fuel Dlscharge Projectlons: 1984 to 2020," PNL-5396, Aprll 1985 (data only glven through 1997)

2. From transinittal from R. E. Hoskins, March 20, 1985 


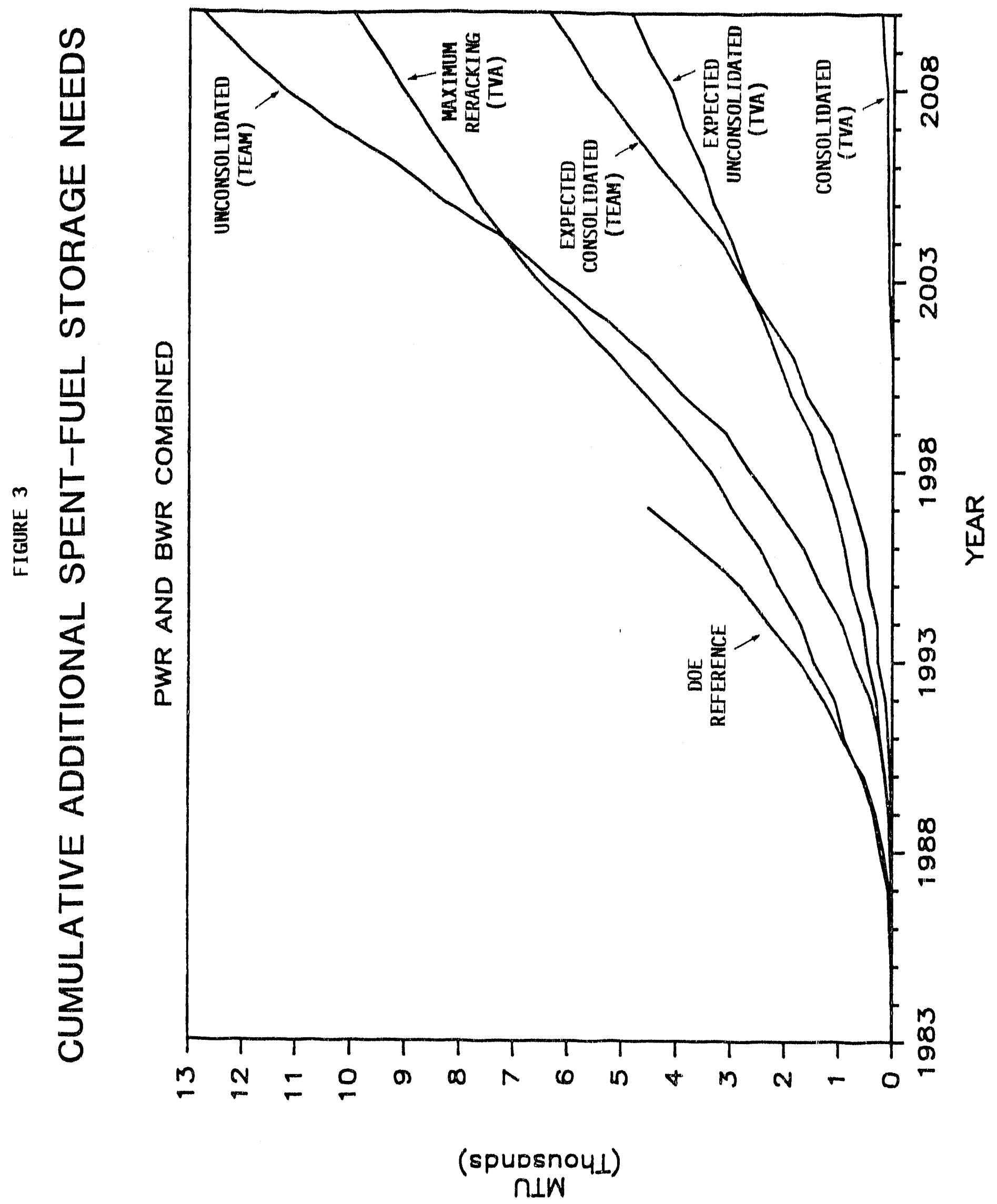


Table 6 shows the reference cumulattve additional storage needs by number of PWR and BWR assemblies for the DOE reference case, the Team unconsolldated case, and the Team expected :msolldated case. Flgures $4 a$ and $4 b$ compare the PWR and BWR results, respectlely, in graphlcal form. The following summary table compares the cumulative ns 3 minbly storage needs in five-year tncrements; again the year 1997 is shown.

Cumulative Additional Spent-Fuel Storage Needs (Number of Assembltes)

(Reference Cases)

\begin{tabular}{|c|c|c|c|c|c|c|c|}
\hline & \multirow{2}{*}{\multicolumn{2}{|c|}{$\begin{array}{c}\text { DOE } \\
\text { Reterence } \\
\text { PWR }\end{array}$}} & \multicolumn{5}{|c|}{ Team } \\
\hline & & & PWR & Jatod BWR & & $\begin{array}{l}x p a c t e d \\
\text { WR }\end{array}$ & $\begin{array}{c}\text { of clated } \\
\text { BWR: }\end{array}$ \\
\hline 1985 & 0 & 0 & 0 & 0 & 0 & & 0 \\
\hline 1990 & 1.077 & 483 & $144(-86.6)^{*}$ & $556(+15.1)$ & 112 & $(-89.6)$ & $0(-100)$ \\
\hline 1995 & 4,115 & 6,069 & $1,473(-64.2)$ & $3.897 \quad(-35.8)$ & 607 & $(-85.2)$ & $1,086(-82.1)$ \\
\hline 1997 & 6,643 & 9,503 & $2,562(-61.4)$ & $5,840(-38.5)$ & 852 & $(-87.2)$ & $1,750(-81,6)$ \\
\hline 2000 & -- & $-\cdots$ & 5,341 & 9,030 & 2,132 & & 3,777 \\
\hline 2005 & $-\cdots$ & -- & 12,065 & 17,047 & 5,132 & & 8,636 \\
\hline 2010 & -- & -- & 18,298 & 26,874 & 9,133 & & 13,411 \\
\hline $\begin{array}{l}\text { Year of } \\
\text { First Neod }\end{array}$ & 1936 & 1987 & 1989 & 1988 & & 89 & 1992 \\
\hline
\end{tabular}

The lower storage needs demonstrated by the Team unconsolidated estimates are due to lower fuel discharge estimates, changes in storage capacity, additional shipments, and on-site transfer. Consolidation clearly leads to a significant further reduction in additional storage needs.

* Percent difference from DOE reference 
TABLE 6

CUMULATIVE ADDITIONAL SPENT-FUEL. STORAEE NEEDS

REFERENCE CASES

(Assemb||as)

\begin{tabular}{|c|c|c|}
\hline & PWR & EWR \\
\hline 1983 & 0 & 0 \\
\hline 1984 & 0 & 0 \\
\hline 1985 & 0 & 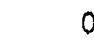 \\
\hline 1986 & 50 & $c$ \\
\hline 1987 & 120 & 49 \\
\hline 1988 & 379 & 49 \\
\hline 1989 & 674 & 221 \\
\hline 1990 & 1,077 & 483 \\
\hline 1991 & 1,560 & 1,584 \\
\hline 1992 & 2,113 & 2,176 \\
\hline 1993 & 2,614 & 3,460 \\
\hline 1994 & 3,278 & 5,185 \\
\hline 1995 & 4,115 & 6,069 \\
\hline 1996 & 5,271 & 7,838 \\
\hline 1997 & 6,643 & 9,503 \\
\hline 1998 & -- & \\
\hline 1999 & -- & \\
\hline 2000 & -- & \\
\hline 2001 & $-\cdots$ & \\
\hline 2002 & -- & \\
\hline 2003 & $-\infty$ & \\
\hline 2004 & -- & \\
\hline 2005 & -- & \\
\hline 2006 & $-\infty$ & \\
\hline 2007 & -- & \\
\hline 2008 & -- & \\
\hline 2009 & -- & \\
\hline 2010 & -- & \\
\hline
\end{tabular}

\begin{tabular}{|c|c|}
\hline \multicolumn{2}{|c|}{$\begin{array}{c}\text { Toam } \\
\text { Unconsolldatad }\end{array}$} \\
\hline PWR & BWR \\
\hline 0 & 0 \\
\hline 0 & 0 \\
\hline 0 & 0 \\
\hline 0 & 0 \\
\hline 0 & 0 \\
\hline 0 & 43 \\
\hline 63 & 116 \\
\hline 144 & 556 \\
\hline 304 & 737 \\
\hline 471 & 1,164 \\
\hline 732 & 2,085 \\
\hline 1,091 & 2,599 \\
\hline 1,473 & 3,897 \\
\hline 2,004 & 4,407 \\
\hline 2,562 & 5,840 \\
\hline 3.282 & 6,892 \\
\hline 4,084 & 7,476 \\
\hline 5,341 & 9,030 \\
\hline 6,510 & 9,777 \\
\hline 7,630 & 11,543 \\
\hline 9,063 & 13,351 \\
\hline 10,233 & 15,037 \\
\hline 12,065 & 17,047 \\
\hline 13,234 & 19,122 \\
\hline 14,880 & 21,348 \\
\hline 16,112 & 23,774 \\
\hline 17,285 & 25,475 \\
\hline 18,298 & 26,874 \\
\hline
\end{tabular}

\begin{tabular}{|c|c|}
\hline \multicolumn{2}{|c|}{$\begin{array}{l}\text { Team Expected } \\
\text { Consolidated }\end{array}$} \\
\hline PWR & BWE \\
\hline 0 & 0 \\
\hline 0 & 0 \\
\hline 0 & 0 \\
\hline 0 & 0 \\
\hline 0 & 0 \\
\hline 0 & 0 \\
\hline 31 & 0 \\
\hline 112 & 0 \\
\hline 213 & 0 \\
\hline 267 & 146 \\
\hline 418 & 561 \\
\hline 463 & 561 \\
\hline $60 \%$ & 1,086 \\
\hline 703 & 1,086 \\
\hline 852 & 1,750 \\
\hline 1,117 & 2,423 \\
\hline 1,510 & 2,859 \\
\hline 2,132 & 3,777 \\
\hline 2,560 & 4,213 \\
\hline 3,077 & 5,596 \\
\hline 3,638 & 6,705 \\
\hline 4,169 & 7,746 \\
\hline 5,132 & 8,636 \\
\hline 5,950 & 9,941 \\
\hline 6,893 & 10,637 \\
\hline 7,645 & 11,886 \\
\hline 8,406 & 12,515 \\
\hline 9,133 & 13,411 \\
\hline
\end{tabular}

1. From "Reactor-Speclfle Spent-Fuel Dlscharge Projectlons: 1984 to 2020," PNL-5396, Aprll 1985 


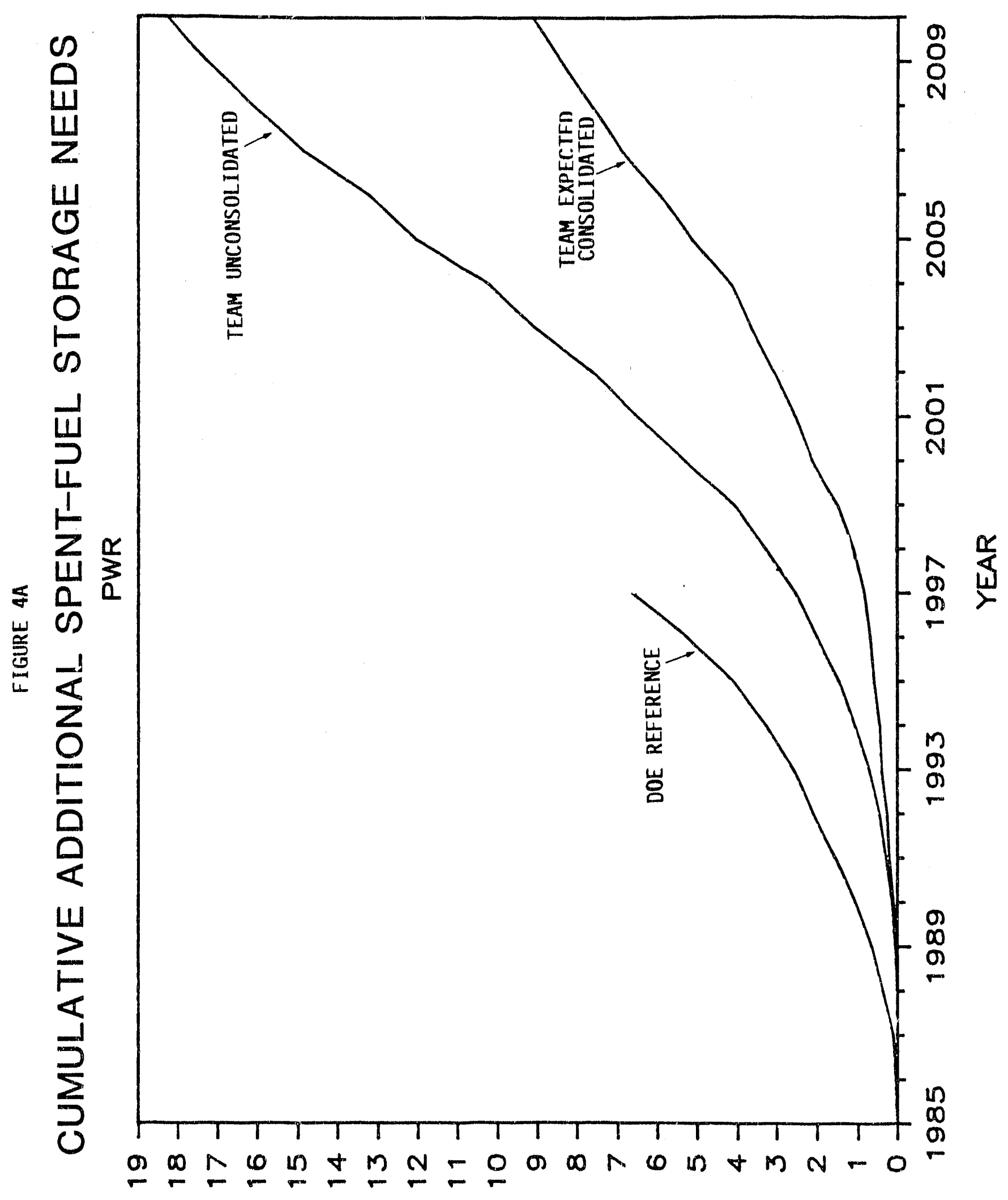

(spuosno41)

SヨI7日W $\exists S S \forall$ 


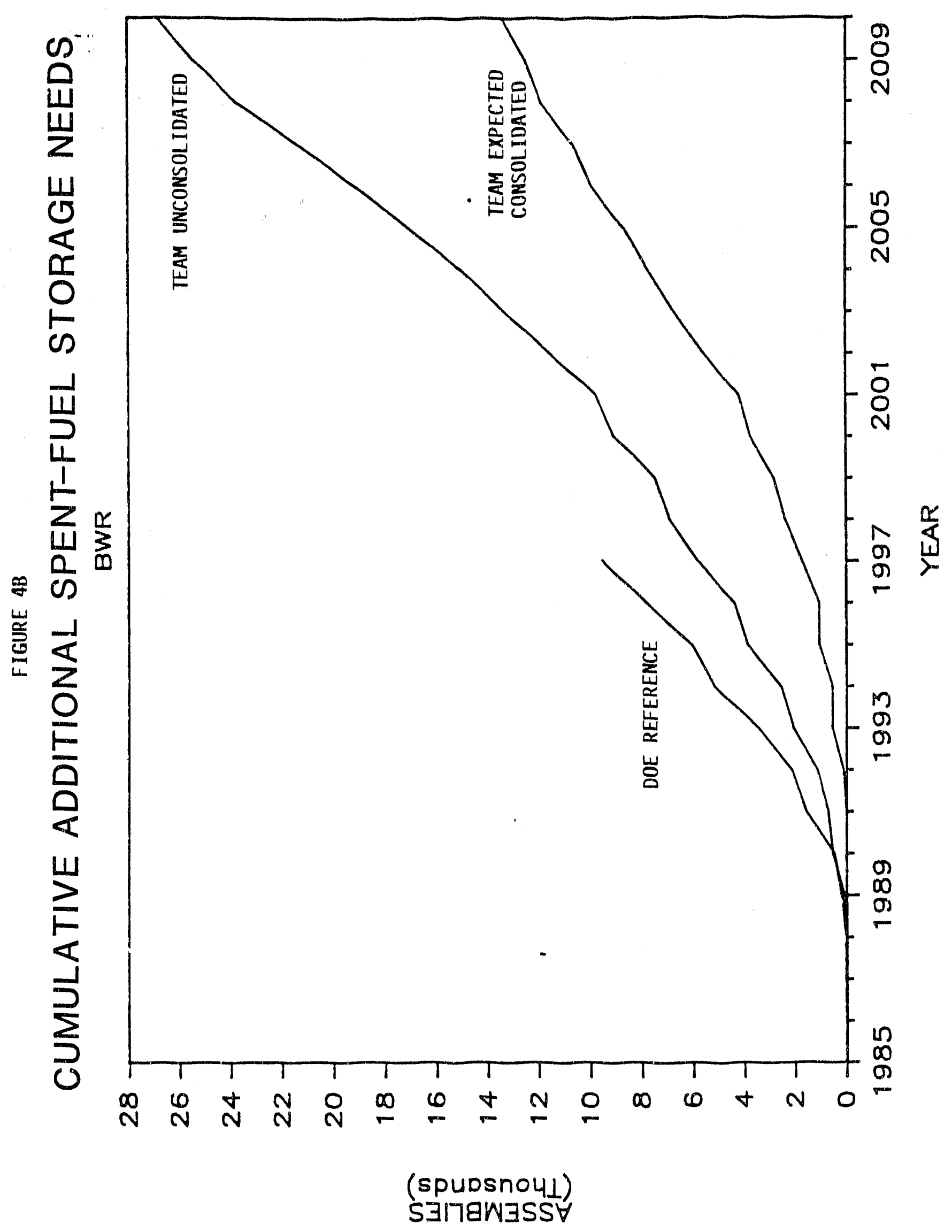




\section{SECTION 3 \\ SENSITIVITY ANALYSES ON SPENT-FUEL DISCHARGES AND THE NEED FOR ADDITIONAL STORAGE}

\section{A. Team Spent-Fuel Discharge Estimates}

In addition to the reference spent-fuel discharge case, the Team examined three other discharge scenarios, namely:

- Constant burnup at current levels

- $\quad 50$ percent capacity factor

- No new reactor orders

In each case, other reference case assumptions were retained except for the one for which sensitivity was being analyzed. The following summary table provides an overview of the reference case assumptions compared to the assumptions for the sensitivity case:

Sensitivity Case

1. Constant burnup at current levels PWR - 32,000 MWD/MT BWR - 28,000 MWD/MT

2. Average 60 percent capacity factur

3. No replacement reactors
Reference Case

Increasing burnup by 1996 to:

PWR - 43,000 MWD/MT

BWR - 36,000 MWD/MT

Average 64 percent capacity factor

791,100 MWe replacement reactors added from 2004 to 2020

Table 7 summarizes the spent-fuel discharges from each of the sensitivity cases and compares them with the Team reference case. Results are provided in numbers of assemblies for PWRs and BWRs separately in five-year increments from 1985 to 2020. Percent differences from the reference case are al so provided. Constant burnup at current. levels results in an increase in the number of discharged assemblies of about 11 percent through 2000 and 14 to 15 percent through 2020. The result of operating at a 60 percent capacity factor (instead of 64 percent) is a decrease in cumulative discharges of about 5 

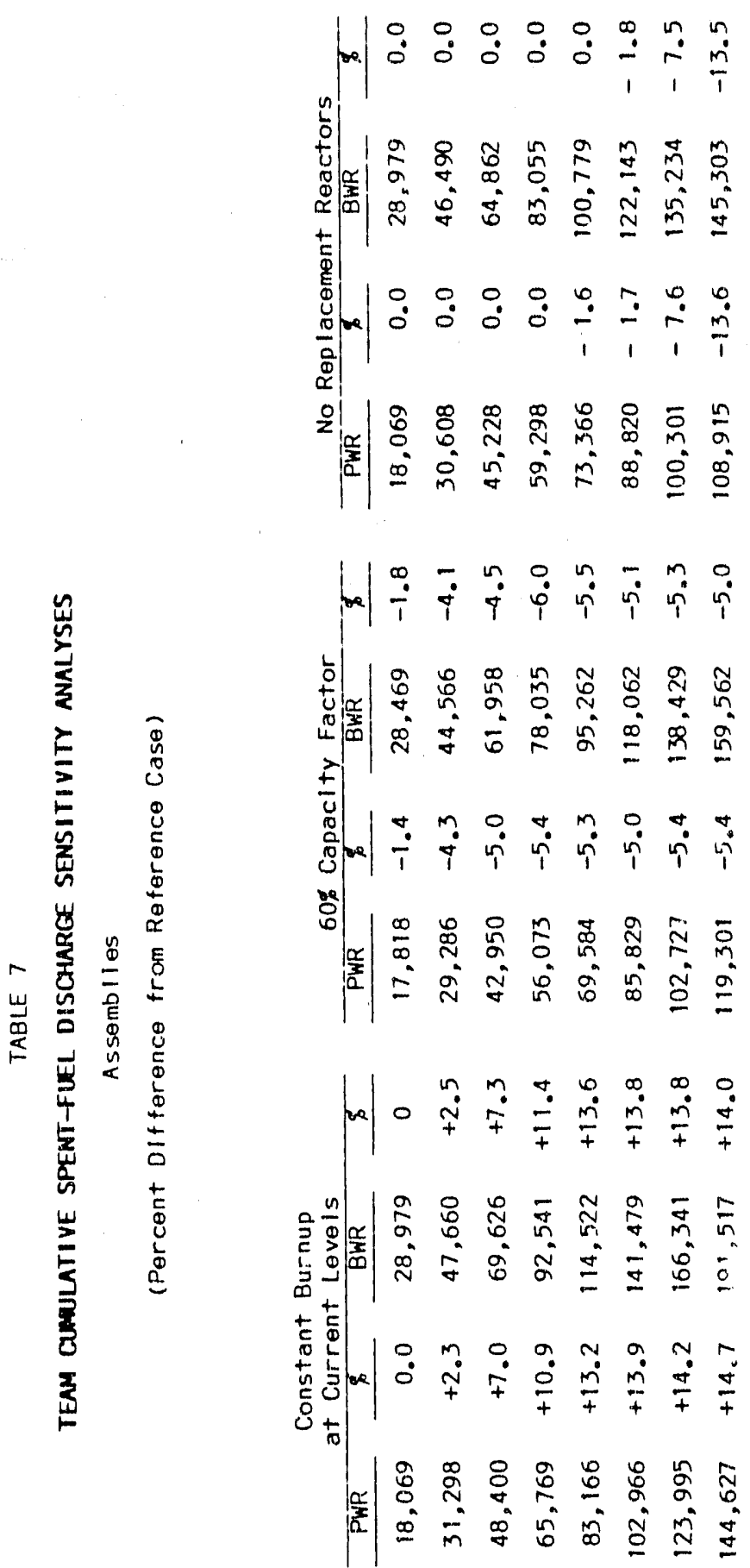

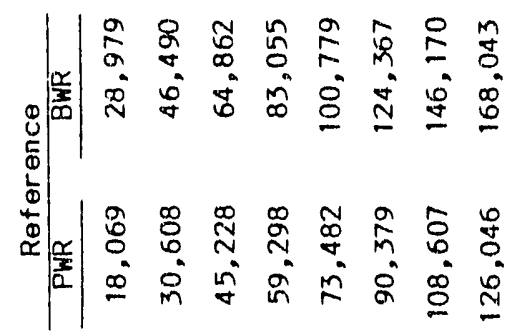

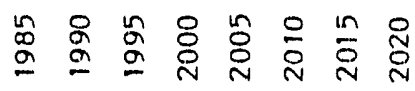


percent. In the no new reactor case, by 2020 there is a decrease in the cumulative quantity of fuel discharged of about 14 percent because of the decrease in number of reactors involved.

\section{B. Additional Storage Needs}

1. DOE. In addition to its reference case without transshipment, DOE analyzed a case for additional storage needs assuming transshipment between like reactors (BWR or PWR) within the same utility. The differences between the DOE cases with and without transshipment are shown in the following summary table.

\section{Cumulative Additional Spent-Fuel Storage Needs (DOE) Assemblies}

\begin{tabular}{|c|c|c|c|c|}
\hline & \multicolumn{2}{|c|}{$\begin{array}{l}\text { Reference Without } \\
\text { Transshipment }\end{array}$} & \multicolumn{2}{|c|}{ With Transshipment } \\
\hline & PWR & BWR & PWR & BWR \\
\hline 1985 & 0 & 0 & 0 & 0 \\
\hline 1986 & 50 & 0 & $0(-100)$ & 0 \\
\hline 1987 & 120 & 49 & $0(-100)$ & $49<0$ \\
\hline 1988 & 379 & 49 & $0(-100)$ & $49>0$ \\
\hline 1989 & 674 & 221 & $0(-100)$ & $221<0$ \\
\hline 1990 & 1,077 & 483 & $21(-98.1)$ & $221(-54.2)$ \\
\hline 1995 & 4,115 & 6,069 & $1,671(-59.4)$ & $2,327 \quad(-61.7)$ \\
\hline 1997 & 6,643 & 9,503 & $3,763(-43.4)$ & $5,504)(-42.1$ \\
\hline
\end{tabular}

The numbers in parentheses indicate the percent difference from the DOE reference case. For PWRs, transshipment delays the need for additional spent-fuel storage from 1986 to 1990. For BWRs, the small initial need is not delayed. However, for both PWRs and BWRs, the cumulative need for additional storage through 1997 is decreased by over 40 percent. 
2. Team. The Team reference cases, unconsolidated and expected consolidated, include currently planned shipments and on-site transfers but do not include transshipments. Two sensitivity cases are examined for each reference case:

- No additional shipments beyond what has already occurred and no on-site transfers.

- Transshipment in addition to planned shipments and on-site transfers.

The no additional shipments case provides an upper bound on additional storage needs. The transshipment case represents the Team's lower bound. It includes transshipment between like reactors (PWR or BWR) within the same utility. An exception is the transshipment of spent fuel from Brunswick (BWR) to Harris (PWR). Table 8 shows the additional spent-fuel storage needs for the two Team sensitivity cases through 2010 and the reference cases. From Table 8 it can be seen that:

- For the no additional shipment/no on-site transfer cases, there is a significant advance in the date of the need for additional storage for PWRs. As expected, there is a substantial increase in the cumulative need for additional storage for both PWRs and BWRs through 2010.

- For the transshipment cases, substantial reductions in the additional needs for storage occur and the dates of the need are del ayed.

Table 9 highlights the differences between the reference cases and the sensitivity cases in five-year increments. Percent differences from the reference case and the year of first need for additional spent-fuel storage are also shown. Data are shown separately for the unconsolidated and expected consolidated fuel cases.

For the unconsolidated case and no on-site transfer scenario, the first date for additional storage is advanced from 1989 to 1985 for PWRs and remains unchanged (1988) for BWRs. There are substantial increases in additional storage needs, compared to the reference case, which are most significant in the time period 1990 to 1995. 


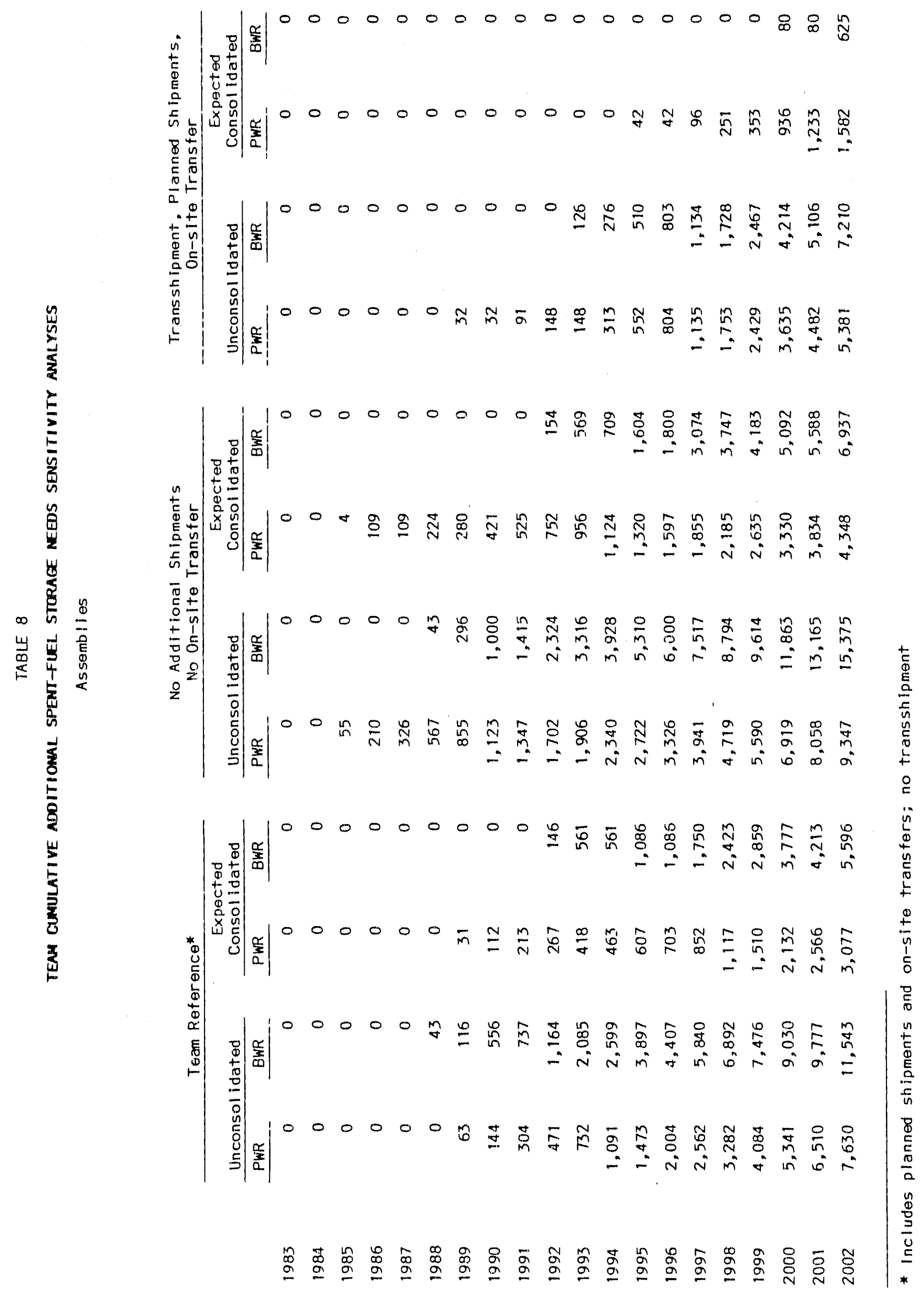




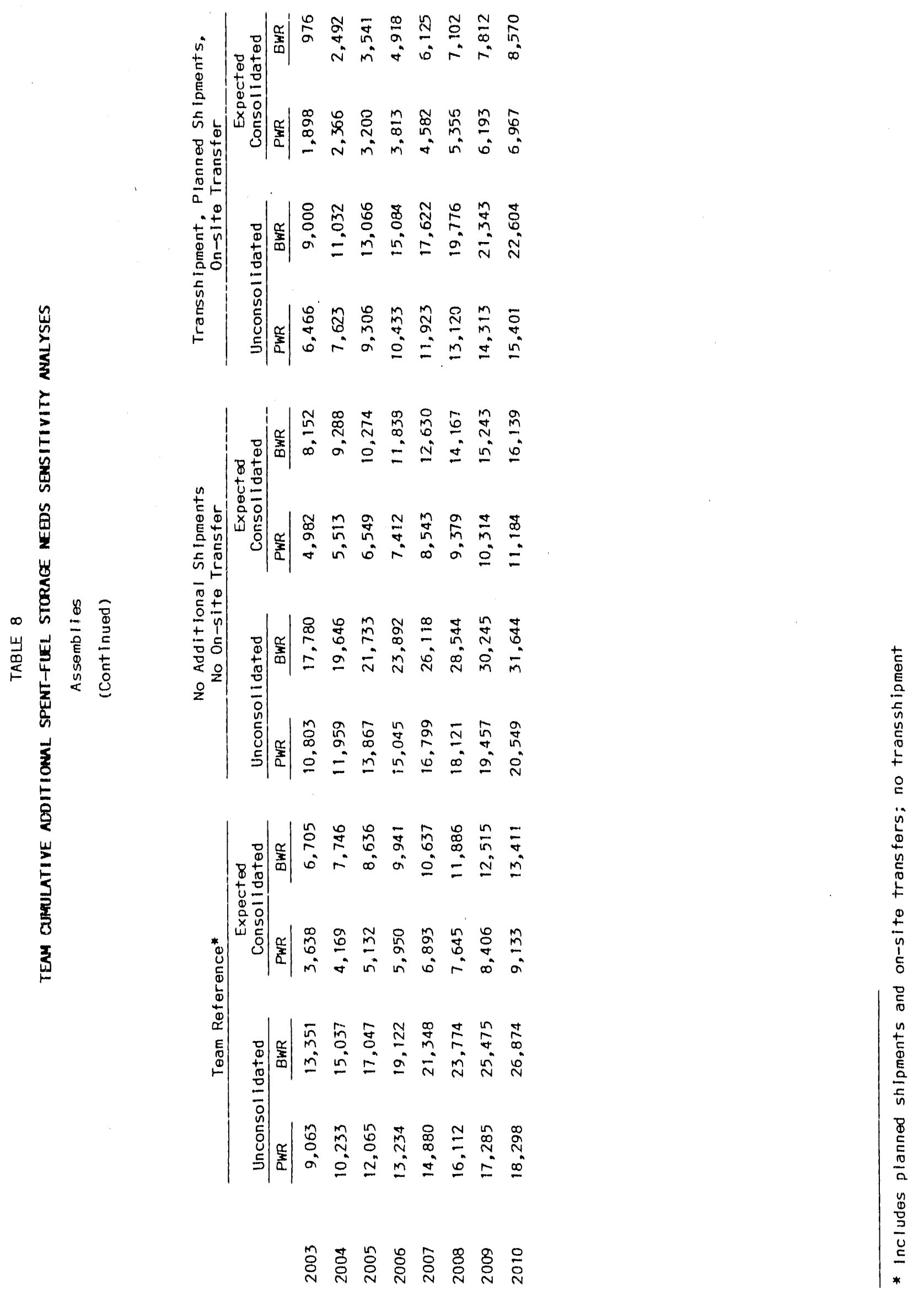


TABLE 9

TENM CUNULATIVE ASSEMBLY AODITIONAL SPENT-FLEL STORAGE NEEDS SENSITIVITY

(Percent Dltference from Reference Cases)

Unconsol Idatod Case

\begin{tabular}{|c|c|c|c|c|c|c|c|c|c|c|}
\hline & Team $R_{\theta}$ & arence & & $\begin{array}{l}d 81+10 n \\
\text { On-s It }\end{array}$ & $\begin{array}{l}\text { Shlpmer } \\
\text { Transter }\end{array}$ & & $\begin{array}{r}\text { Tr } \\
\text { Shilom }\end{array}$ & $\begin{array}{l}n s s h 1 p \\
n+5,0 \\
\end{array}$ & $\begin{array}{l}\text { nt, Plan } \\
\text { site Tra }\end{array}$ & $\begin{array}{l}\text { ed } \\
\text { ster }\end{array}$ \\
\hline & PWR & BWR & PWR & 8 & BKR & $\%$ & PWR & $\not$ & BWR & $q$ \\
\hline 1985 & 0 & 0 & 55 & - & 0 & 0.0 & 0 & 0.0 & 0 & 0.0 \\
\hline 1990 & 144 & 556 & 1,123 & +680.0 & 1,000 & +79.9 & 32 & -77.8 & 0 & -100.0 \\
\hline 1995 & 1,473 & 3,897 & 2,722 & +84.8 & 5,310 & +36.3 & 552 & -62.5 & 510 & -86.9 \\
\hline 2000 & 5,341 & 9,030 & 6,919 & +29.5 & 11,863 & +31.4 & 3,635 & -31.9 & 4,214 & -53.3 \\
\hline 2005 & 12,065 & 17,047 & 13,867 & +14.9 & 21,733 & +27.5 & 9,306 & -22.9 & 13,066 & -23.4 \\
\hline 2010 & 18,298 & 26,874 & 20,549 & +12.3 & 31,644 & +17.7 & 15,401 & -15.8 & 22,604 & -15.9 \\
\hline $\begin{array}{l}\text { ear of } \\
\text { First Neod }\end{array}$ & 1989 & 1988 & 1985 & & 1988 & & 1989 & & 1993 & \\
\hline
\end{tabular}

Expected Consolldated Case

1985

1990

1995

2000

2005

2010

Year of

First Neod
1988

1989

\begin{tabular}{|c|c|c|c|c|c|c|c|c|c|}
\hline PWR & BWR & PWR & 8 & BWR & 8 & PWR & $\%$ & BWR & 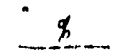 \\
\hline 0 & 0 & 4 & - & 0 & 0.0 & 0 & 0.0 & 0 & 0.0 \\
\hline 112 & 0 & 421 & +276.0 & 0 & 0.0 & 0 & -100.0 & 0 & 0.0 \\
\hline 607 & 1,086 & 1,320 & +117.0 & 1,604 & +47.7 & 42 & -93.1 & 0 & -100.0 \\
\hline 2,132 & 3,777 & 3,330 & +56.2 & 5,092 & +34.8 & 936 & -56.1 & 80 & -97.9 \\
\hline 5,132 & 8,635 & 6,549 & +27.6 & 10,274 & +19.0 & 3,200 & -37.6 & 3,541 & -59.0 \\
\hline 9,133 & 13,411 & 11,184 & +22.5 & 16,139 & +20.3 & 6,967 & -23.7 & 8,570 & -36.1 \\
\hline 1989 & 1992 & 1985 & & 1992 & & 1995 & & 2000 & \\
\hline
\end{tabular}

* Includes planned shlpments and on-slte transfer; no transshlpment 
For the unconsolidated case with transshipment, the first date for additional storage is delayed from 1988 to 1993 for BWRs and rematns unchanged (1989) for PWRs. Both PWRs and BWRs exhtblt signiffcant reductions in additional storage needs, which are again most signtflcant in the perfod 1990 to 1995.

Similar tendenctes are shown for the expected consolidated cases. 


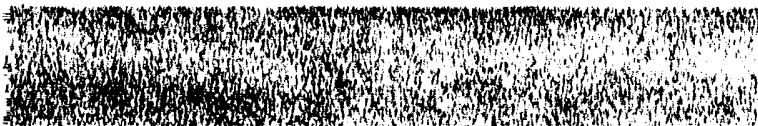

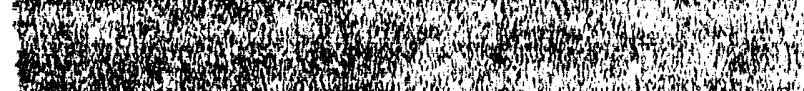

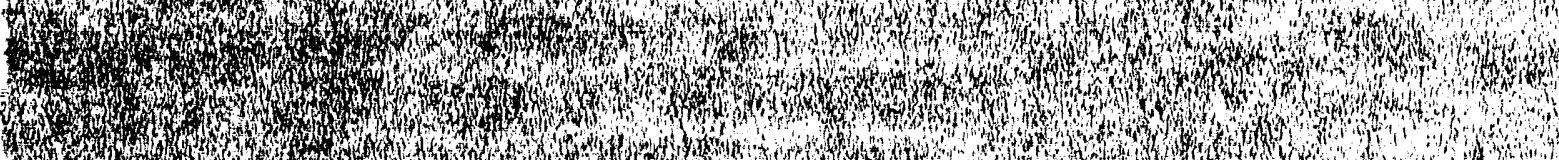

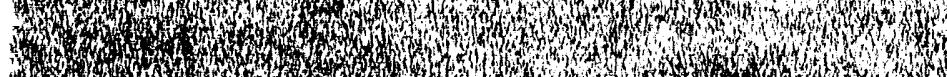

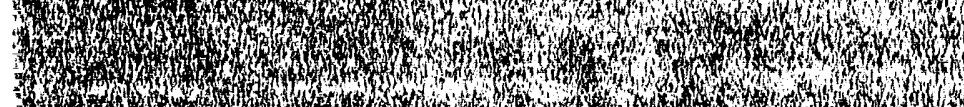

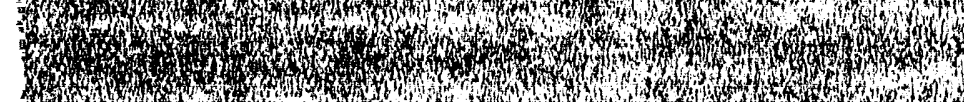

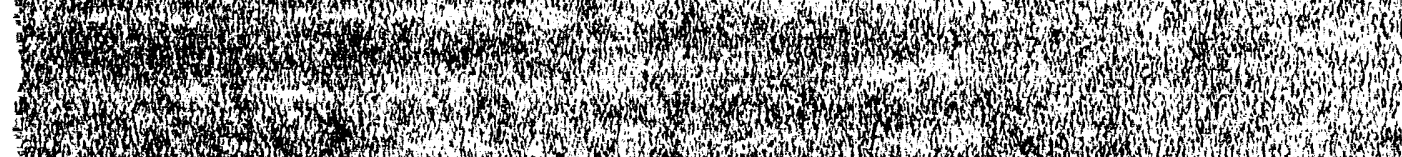

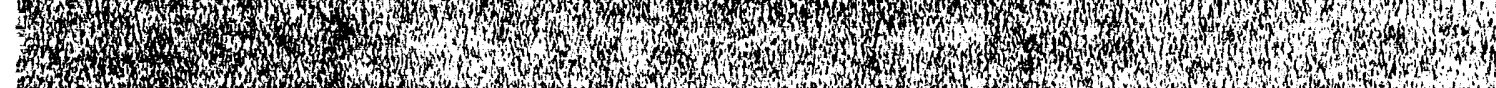

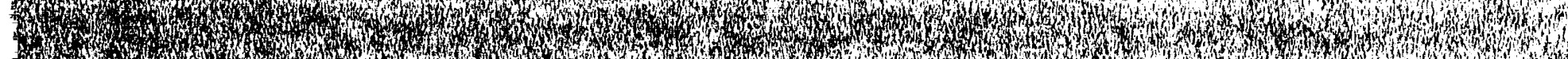

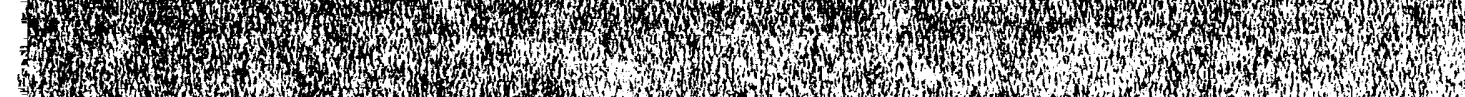

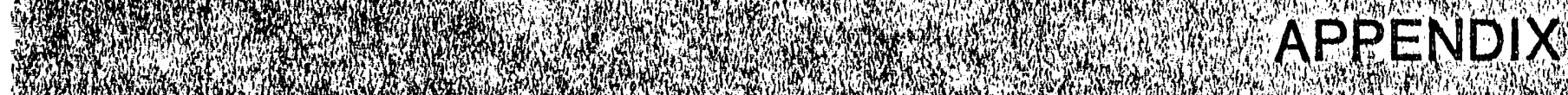

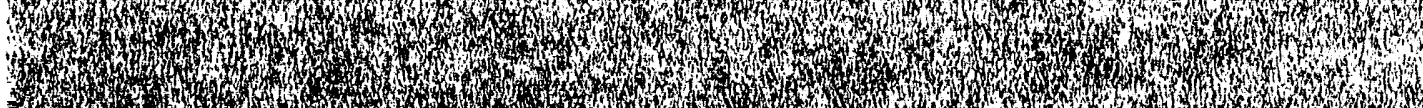

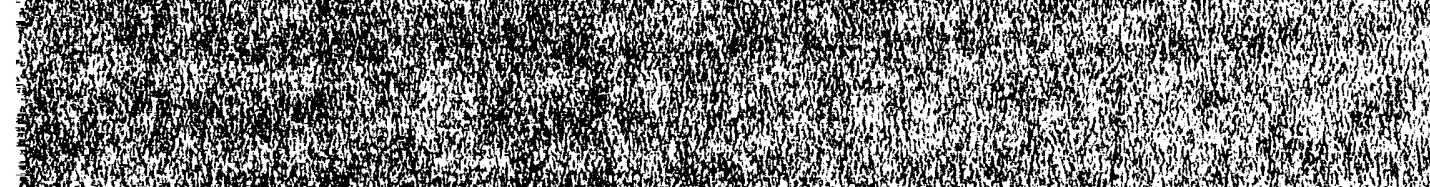

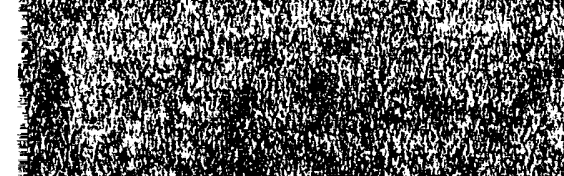

年,

ㄴ.

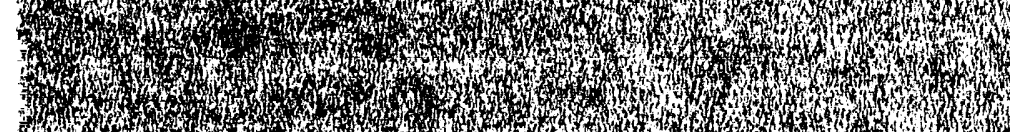

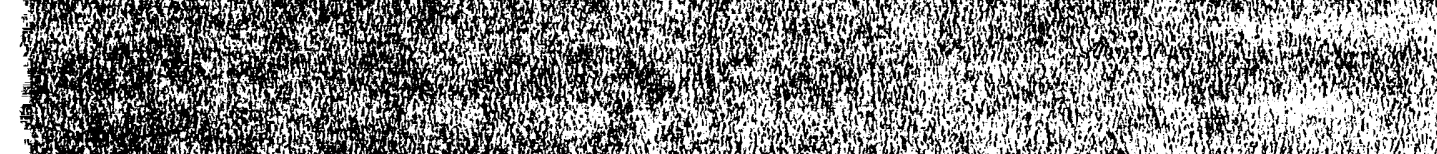

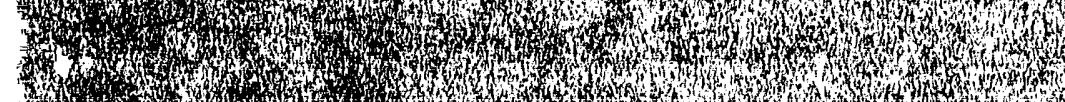

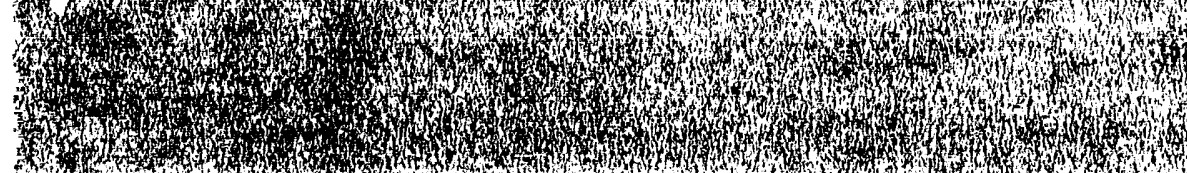

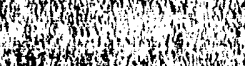

thot

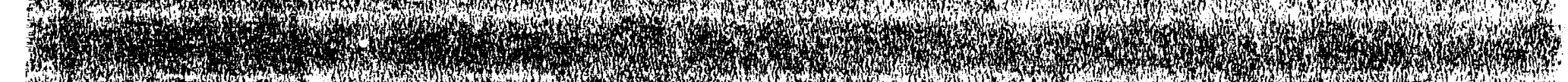

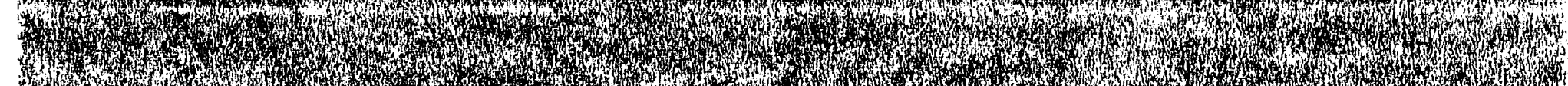

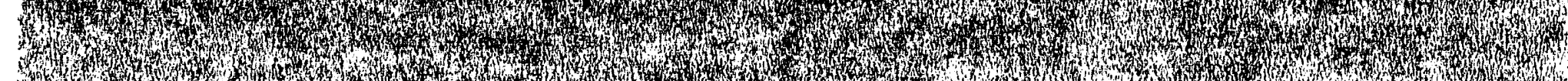

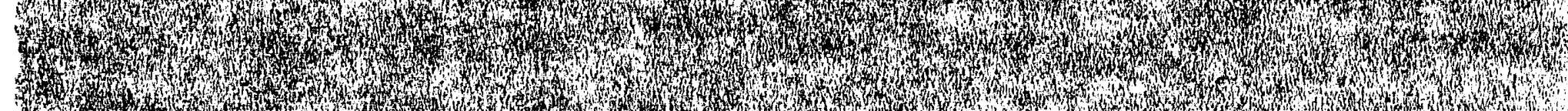

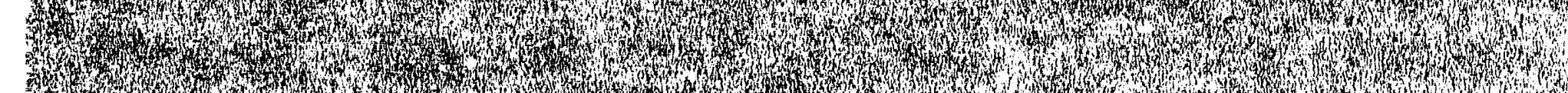

1.

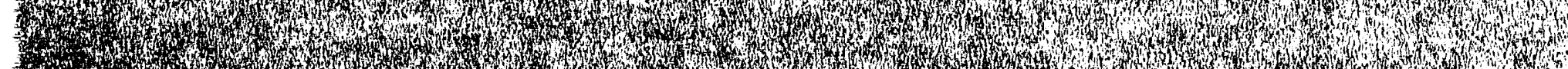

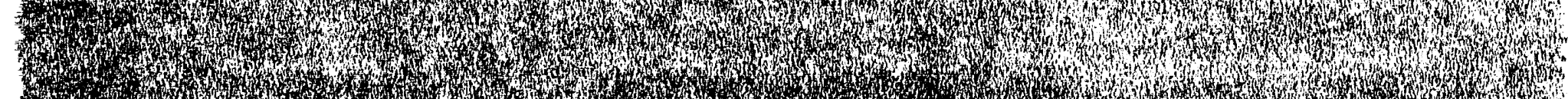

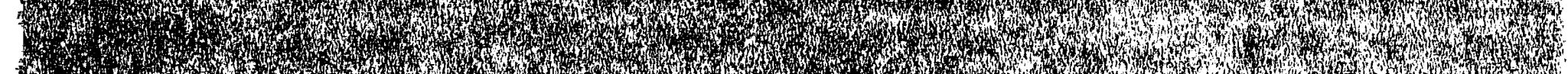

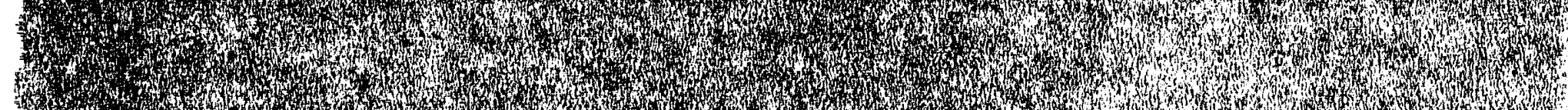

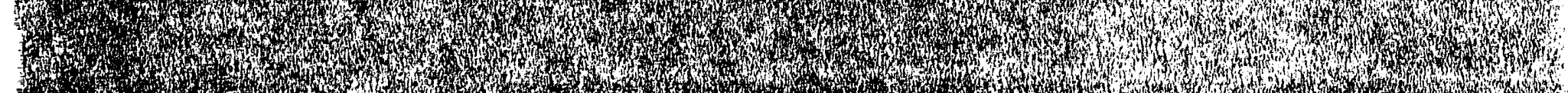

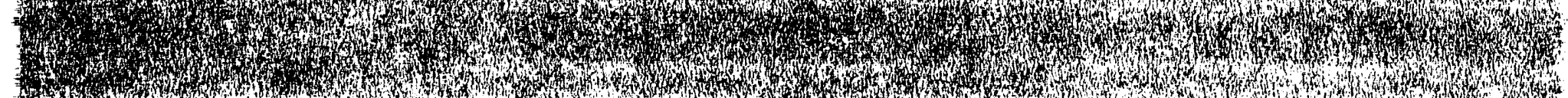


APPENDIX A

STORAGE CAPACITIES AT TEAM REFERENCE REACTORS THROUGH 2000

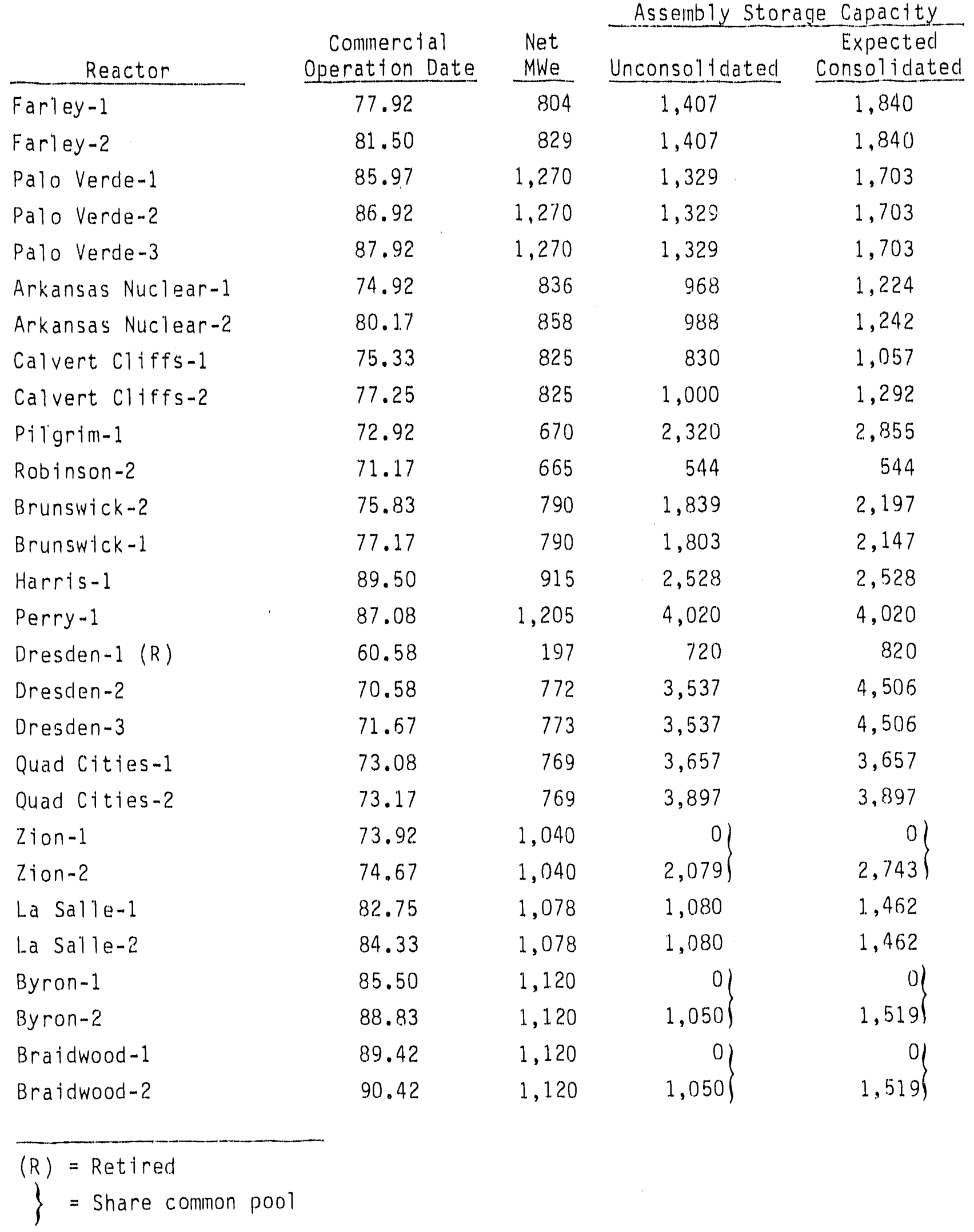


APPENDIX A

STORAGE CAPACITIES AT TEAM REFERENCE REACTORS THROUGH 2000

(Cont. i lued)

\begin{tabular}{|c|c|c|c|c|}
\hline \multirow{2}{*}{ Reactor } & \multirow[b]{2}{*}{$\begin{array}{c}\text { Commercial } \\
\text { Operation Date } \\
\end{array}$} & \multirow[b]{2}{*}{$\begin{array}{l}\mathrm{Net} \\
\text { MWe }\end{array}$} & \multicolumn{2}{|c|}{ Assembly Storage Capactty } \\
\hline & & & Unconsolidated & $\begin{array}{c}\text { Expected } \\
\text { Consol tdated }\end{array}$ \\
\hline Connecttcut Yankee & 68.00 & 555 & 1,168 & 1,523 \\
\hline Indtan Point-1 (R) & 62.75 & 262 & 756 & 1,004 \\
\hline Indtan Potnt-2 & 74.50 & 849 & 980 & 1,232 \\
\hline Big Rock Point & 63.17 & 64 & 545 & 710 \\
\hline Palisades & 71.92 & 635 & 892. & 1,108 \\
\hline La Crosse & 69.83 & 48 & 440 & 565 \\
\hline Ferme-2 & 85.92 & 1,123 & 2,305 & 2,681 \\
\hline Oconee-1 & 73.50 & 860 & $0\}$ & 0) \\
\hline Oconee-2 & 74.67 & 860 & $1,312\}$ & $1,651\}$ \\
\hline Oconee- 3 & 74.92 & 860 & 825 & 1,024 \\
\hline Mc Guire-1 & 81.92 & 1,180 & 1,463 & 1,916 \\
\hline Mc Gutre-2 & 84.17 & 1,180 & 1,463 & 1,913 \\
\hline Catawba-1 & 85.42 & 1,145 & 3,000 & 4,058 \\
\hline Catawba-2 & 87.00 & 1,145 & 3,000 & 4,058 \\
\hline Beaver Valley-1 & 76.75 & 810 & 833 & 1,041 \\
\hline Beaver Valley-2 & 88.00 & 852 & 1,088 & 1,396 \\
\hline Crystal River-3 & 77.17 & 782 & 1,157 & 1,490 \\
\hline Turkey Point-3 & 72.92 & 646 & 1,404 & 1,846 \\
\hline Turkey Point-4 & 73.67 & 646 & 1,404 & 1,842 \\
\hline St. Lucte-1 & 76.92 & 817 & 728 & 1,008 \\
\hline St. Lucie-2 & 83.58 & 842 & 1,076 & 1,546 \\
\hline Hatch-1 & 75.92 & 757 & 3,181 & 4,211 \\
\hline Hatch-2 & 79.67 & 771 & 2,845 & 3,743 \\
\hline Vogt le-1 & 90.00 & 1,100 & 936 & 1,343 \\
\hline River Bend-1 & 86.92 & 934 & 3,172 & 4,052 \\
\hline Clinton-1 & 87.67 & 950 & 2,672 & 3,296 \\
\hline
\end{tabular}

\footnotetext{
$(R)=$ Retired

\}$=$ Share common pool
} 
APPENDIX A

STORAGE CAPACITIES AT TEAM REFERENCE REACTORS THROUGH 2000

(Cont inued)

\begin{tabular}{|c|c|c|c|c|}
\hline \multirow[b]{2}{*}{ Reactor } & \multirow[b]{2}{*}{$\begin{array}{c}\text { Conimerctal } \\
\text { Operation Date }\end{array}$} & \multirow[b]{2}{*}{$\begin{array}{l}\text { Net } \\
\text { MWe }\end{array}$} & \multicolumn{2}{|c|}{ Assembly Storage Capactty } \\
\hline & & & Unconsolitdated & $\begin{array}{c}\text { Expected } \\
\text { Consolidated }\end{array}$ \\
\hline D. C. Cook-1 & 75.58 & 1,044 & 01 & $0\}$ \\
\hline D. C. COOK-2 & 78.50 & 1,082 & $2,270\}$ & $2,959\}$ \\
\hline Duane Arnold & 74.42 & 515 & 2,050 & 2,616 \\
\hline Oyster Creek & 69.92 & 620 & 2,600 & 3,241 \\
\hline Wolf Creek & 85.75 & 1,150 & 1,340 & 1,733 \\
\hline Waterford-3 & 85.92 & 1,104 & 1,366 & 1,760 \\
\hline Maine Yankee & 72.92 & 810 & 1,476 & 1,907 \\
\hline TMI -1 & 74.67 & 776 & 2,283 & 3,043 \\
\hline Grand Gu1f-1 & 85.00 & 1,250 & 5,148 & 5,148 \\
\hline Cooper & 74.50 & 764 & 2,566 & 3,361 \\
\hline Nine Mile Polnt-1 & 69.92 & 610 & 2,776 & 3,473 \\
\hline Nine Mtle Point-2 & 89.17 & 1,080 & 4,049 & 5,128 \\
\hline Mills stone-1 & 70.92 & 654 & 2,184 & 2,655 \\
\hline Mi11 stone-2 & 75.92 & 864 & 667 & 913 \\
\hline Mill stone- 3 & 88.17 & 1,159 & 1,836 & 2,426 \\
\hline Monticello & 71.50 & 536 & 2,237 & 2,845 \\
\hline Prairie Island-1 & 73.92 & 503 & $0)$ & $0\}$ \\
\hline Prairie Island-2 & 74.92 & 500 & $1,574\}$ & $2,068\}$ \\
\hline Fort Calhoun-1 & 73.67 & 478 & 728 & 926 \\
\hline Humboldt Bay (R) & 63.58 & 63 & 486 & 605 \\
\hline Diablo Canyon-1 & 85.33 & 1,084 & 1,400 & 1,612 \\
\hline Diablo Canyon-2 & 86.17 & 1,106 & 1,400 & 1,612 \\
\hline Susquehanna-1 & 83.42 & 1,052 & 2,840 & 3,613 \\
\hline Susquehanna-2 & 85.08 & 1,052 & 2,840 & 3,613 \\
\hline Peach Bottom-2 & 74.50 & 1,051 & 2,816 & 3,418 \\
\hline Peach Bottom-3 & 74.92 & 1,035 & 2,816 & 3,405 \\
\hline
\end{tabular}


APPENDIX A

STORAGE CAPACITIES AT TEAM REFERENCE REACTORS THROUGH 2000

(Cont inued)

\begin{tabular}{|c|c|c|c|c|}
\hline \multirow{2}{*}{ Reactor } & \multirow[b]{2}{*}{$\begin{array}{c}\text { Commercial } \\
\text { Operation Date } \\
\end{array}$} & \multirow[b]{2}{*}{$\begin{array}{l}\text { Net } \\
\text { MWe } \\
\end{array}$} & \multicolumn{2}{|c|}{ Assembly Storage Capacity } \\
\hline & & & Unconsolidated & $\begin{array}{c}\text { Expected } \\
\text { Consolidated }\end{array}$ \\
\hline Limerick-1 & 88.42 & 1,065 & 2,862 & 3,485 \\
\hline Trojan & 76.33 & 1,080 & 1,408 & 1,845 \\
\hline Fitzpatrick & 75.50 & 810 & 2,434 & 3,020 \\
\hline Indian Point-3 & 76.58 & 965 & 840 & 1,028 \\
\hline Seabrook-1 & 87.92 & 1,194 & 1,220 & 1,575 \\
\hline Salem-1 & 77.42 & 1,079 & 1,170 & 1,489 \\
\hline Salem-2 & 81.75 & 1,104 & 1,170 & 1,520 \\
\hline Hope Creek-1 & 88.00 & 1,067 & 3,666 & 3,666 \\
\hline Ginna & 70.17 & 470 & 1,016 & 1,346 \\
\hline Rancho Seco-1 & 75.25 & 873 & 1,080 & 1,388 \\
\hline Virgil C Summer & 84.00 & 900 & 1,276 & 1,658 \\
\hline San Ono.fre-1 & 68.00 & 436 & 216 & 216 \\
\hline San Onofre-2 & 83.58 & 1,140 & 800 & 800 \\
\hline San Onofre-3 & 84.25 & 1,140 & 800 & 800 \\
\hline South Texas Proj-1 & 88.00 & 1,250 & 2,100 & 2,800 \\
\hline South Texas Proj-2 & 90.08 & 1,250 & 2,100 & 2,800 \\
\hline Browns Ferry-1 & 74.58 & 1,065 & 3,471 & 4,509 \\
\hline Browns Ferry-2 & 75.17 & 1,065 & 3,471 & 4,509 \\
\hline Browns Ferry-3 & 77.17 & 1,065 & 3,471 & 4,359 \\
\hline Sequoyah-1 & 81.50 & 1,128 & $0\}$ & $0\}$ \\
\hline Sequoyah-2 & 82.42 & 1,140 & $1,386\}$ & $1,721\}$ \\
\hline Watts Bar-1 & 85.67 & 1,165 & $0\}$ & 01 \\
\hline Watts Bar-2 & 88.17 & 1,165 & $1,312\}$ & $1,618\}$ \\
\hline Bellefonte-1 & 89.00 & 1,235 & 1,058 & 1,317 \\
\hline Bellefonte-2 & 91.33 & 1,235 & 1,058 & 1,317 \\
\hline
\end{tabular}

\footnotetext{
$(R)=$ Retired

\}$=$ Share common pool
} 
APPENDIX A

STORAGE CAPACITIES AT TEAM REFERENCE REACTORS THROUGH 2000

(Continued)

\begin{tabular}{|c|c|c|c|c|}
\hline \multirow{2}{*}{ Reactor } & \multirow[b]{2}{*}{$\begin{array}{c}\text { Commercial } \\
\text { Operation Date }\end{array}$} & \multirow[b]{2}{*}{$\begin{array}{l}\text { Net } \\
\text { MWe } \\
\end{array}$} & \multicolumn{2}{|c|}{ - Assembly Storage Capacity } \\
\hline & & & Unconsolidated & $\begin{array}{c}\text { Expected } \\
\text { Consolidated } \\
\end{array}$ \\
\hline Comanche Peak-1 & 86.67 & 1,150 & 1,364 & 1,813 \\
\hline Comanche Peak-2 & 88.17 & 1,150 & 1,364 & 1,813 \\
\hline Davis Besse-1 & 78.50 & 890 & 735 & 1,040 \\
\hline Call away -1 & 84.92 & 1,150 & 1,340 & 1,732 \\
\hline Vermont Yankee & 72.83 & 504 & 2,500 & 3,263 \\
\hline Surry-1 & 72.92 & 775 & 01 & $0\}$ \\
\hline Surry-2 & 73.33 & 775 & $1,149\}$ & $1,149\}$ \\
\hline North Anna-1 & 78.42 & 865 & $0\}$ & $0\}$ \\
\hline North Anna-2 & 80.92 & 865 & $1,737\}$ & $2,249\}$ \\
\hline WNP -2 & 84.92 & 1,103 & 2,658 & 3,269 \\
\hline Point Beach-1 & 70.92 & 495 & $0\}$ & $0\}$ \\
\hline Point Beach-2 & 72.75 & 495 & $1,502\}$ & $1,999\}$ \\
\hline Kewaunee & 74.42 & 509 & 990 & 1,305 \\
\hline Yankee & 61.50 & 175 & 721 & 947 \\
\hline
\end{tabular}

\footnotetext{
$(R)=$ Retired

\}$=$ Share common pool
} 


\section{OPTIMIZED TRANSPORTATION SCHEME}

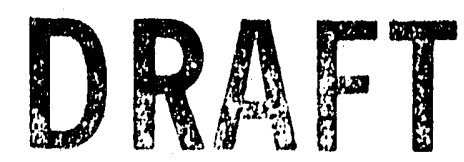

October 1985

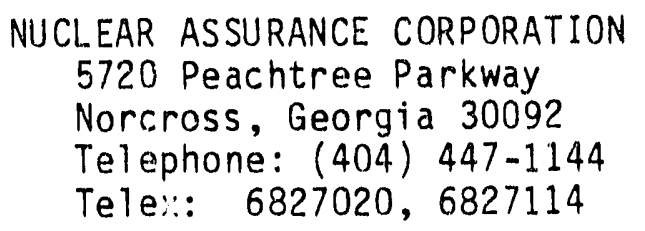

P. 0. Box 40158

Grand Junction, Colorado 81504

Telephone: (303) 245-4320
Weinbergstrasse 9

8001 Zurich, Switzerland Telephone: (01) 470844

Telex: $\quad 57275$

2-21-4 Nishi Azabu

Minato-ku,

Tokyo 106, Japan

Telephone: (03) 4077734

Telex: 2422022

(9) 1985 Nuclear Assurance Corporation

Printed in U,S.A.

NAC C-8591 


\section{NOTICE}

The information contained in this report has been prepared by Nuclear Assurance Corporation based upon data obtained from sources we consider reliable and/or calculations consistent with technical principles we consider applicable. Neither Nuclear Assurance Corporation nor any individual author makes any warranty or representation, expressed or implied, with respect to the accuracy, completeness, or usefulness of the information contained in this report, or assumes any responsibility for liability or damage that may result from the use of any information disclosed in this report.

This report and the information it contains are proprietary to Nuclear Assurance Corporation and provided for the internal use of our customers only. This report, or parts thereof, may not be reproduced in any form, and reproduction is expressly prohibited without the written permission of Nuclear Assurance Corporation. 


\section{OPTIMIZED TRANSPORTATION SCHEME}

The spent-fuel cask handling and transportation capabllities for each plant in the U.S. are the primary factors in detemining the mode of transportation of spent fuel from the reactors. Based on current capabilities and conditions with current cask models, approximately 70 and 30 percent of the reactors are capable of shipping by rail and truck, respectively. However, since conditions are expected to change with respect to shipping spent fuel, an optimized traisportation scheme would detail the optimum and expected transportation modes and cask models.

The optimized transportation scheme was developed by reviewing individual reactor capabilities with respect to cask handiing and transportation capabilities. The reactor and site parameters evaluated to determine the optimum cask and transportation mode included crane capacity, cask set down area dimensions and access capability. The primary source of the reactor and site data was PNL-5384, Spent Nuclear Fuel Shipping Cask Handling Capabilities of Light Water Reactors, April 1985. NAC supplemented these data with reactor and site specific data gathered from recent plant visits where appropriate. The fundamental criterion was to utilize the largest (highest capacity) cask capable of being handled by the reactor and transported effectively. In addition, it was assumed that the 25 ton and 40 ton cask models would be transported on the highway as legal and overweight shipments, respectively. The larger cask models (70, 100 and 125 tons) are assumed to be shipped by rail. Within the evaluation, there are instances in which intermodal shipments (heavy-haul and barge-rail) have been assumed. This analysis has assumed all fuel to be standard PWR and BWR fuel as defined by the DOE utility waste contract. No special cask or transportation mode exceptions have been made for non-standard (e.g., extra long) fuel.

Table 1 lists individual reactor and site values used in the evaluation in addition to the optimum transportation scheme. The notes to the table are an integral part of the evaluation and should be considered when reviewing the results. Of the 119 reactors 1 isted on the table, 75 reactors were determined to be limited to using a 125 ton cask, 25 reactors would be limited to 
transporting a 100 ton cask and only 4 reactors would be 1 imited to a 70 ton cask. The 125, 100 and 70 ton cask models were assumed to be shipped predominantly by rail and represent 87 percent of the reactors. Truck shipments were assumed to be performed by utilizing 40 and 25 ton cask models. There are a total of 10 and 4 reactors that are limited to shipping 40 and 25 ton casks, respectively. Thus, 13 percent of the plants are assumed to perform truck shipments.

The results presented in the optimized transportation scheme have been developed based upon the current data available and current spent-fuel transportition practices. There are several concepts which have the potential to modify the results and reduce the number of spent-fuel cask shipments, but these require further investigation and analysis and are not included in this evaluation. These specific topic areas include the utilization of a transfer $c$ sk, on-site transshipment, transporting the 25 and 40 ton cask on rail, the feasibility of a 150 ton cask and the need for a 70 ton cask model.

For plants limited to 25, 40 and 70 ton cask models because of plant crane capacity, the utilization of a transfer cask and a larger (100 or 125 ton) rail cask could be beneficial in reducing the shipment miles and the number of shipments. The basic concept would be that a large cask would be transported to the site and set up at a staging area by using a mobile crane. The transfer cask would be loaded with spent fuel in the spent-fuel pool and moved to the staging area, where the fuel would be transferred into the larger cask. The required further analysis would entail a plant-by-plant evaluation to determine the feasibility of transporting a larger cask to and from the site, the conceptual design and operation, and the cost/benefit analysis. A similar topic would be on-site transshipment. This concept is described by the situation where there are at least two reactors with separate spent-fuel pools on one site and one reactor has a more limiting conditioning (i.e., a smaller crane capacity) than the other reactor. It is feasible t) transfer or transship from the reactor with the more limiting condition to the other unit and ship to the MRS or repository from the second unit in a larger cask. The additional analysis required would cover the impacts on the utility, including cost, radiation exposure and storage space, and the benefit to the overall system. 
Another area requiring additional investigative analysis is the transportation of truck cusks (25 and 40 ton models) by rail. Based upon inttlal review, this alternative would reduce the shipment miles when placing multtple casks on a train. However, this may increase the cost in terms of raflcars and trailers required and may increase the number of casks required because of possible lower cask utilization. Additional analysis can cover the assumption of intermodal (heavy-haul and barge-rafl) shipments in terms of feasibility, cost and operational procedures. In addition, further analysts can review the cost/benefit to shipping as a common carrier compared to dedicated train.

While reviewing each plant's crane capacity, it was noted that 17 out of 118 reactors have a crane capacity of 150 tons. Based upon our transportation knowledge, 150 ton load casks can be easily handled by the railroad. However, the dimensional limit of 120 inch maximum width for free interchange may be the limiting parameter. This dimensional limit encompasses the entire cask package, primarily including the cask and impact limiters. There may be some specific cask design and materials that would allow the utilization of a 150 ton cask. The cost of cask manufacturing, material availability and specific plant feasibility, amorg other factors, needs to be investigated further. In addition, a 150 ton or larger cask may have an overwhelming benefit in shipping from the MRS to the repository.

It should be noted that DOE has plans to issue two procurement activities of special interest directly related to some of these topics. In the near future DOE has plans to contract for reactor site interface evaluation with respect to spent fuel shipping. There is a great benefit in having qualified, experienced, spent-fuel shipping personnel to evaluate each site as to its actual cask handling situation and site access. In addition, in the Draft Transportation Business Plan, DOE has outilined plans to perform a design completion for a new generation of transportation and dual purpose (storage/transport) casks. DOE is strongly encouraged to continue these and other efforts so as to clearly define the optimum transportation scheme. In 1984, DOE awarded several contracts in the Progam Research and Development Analysis (PRDA) area. The complete results of these contracts should be available in November/December 1985. Several of these contracts and their results could impact the results of this optimum transportation scheme, especially in large cask, mobile consolidation equipment, and dual and universal cask utilization. 


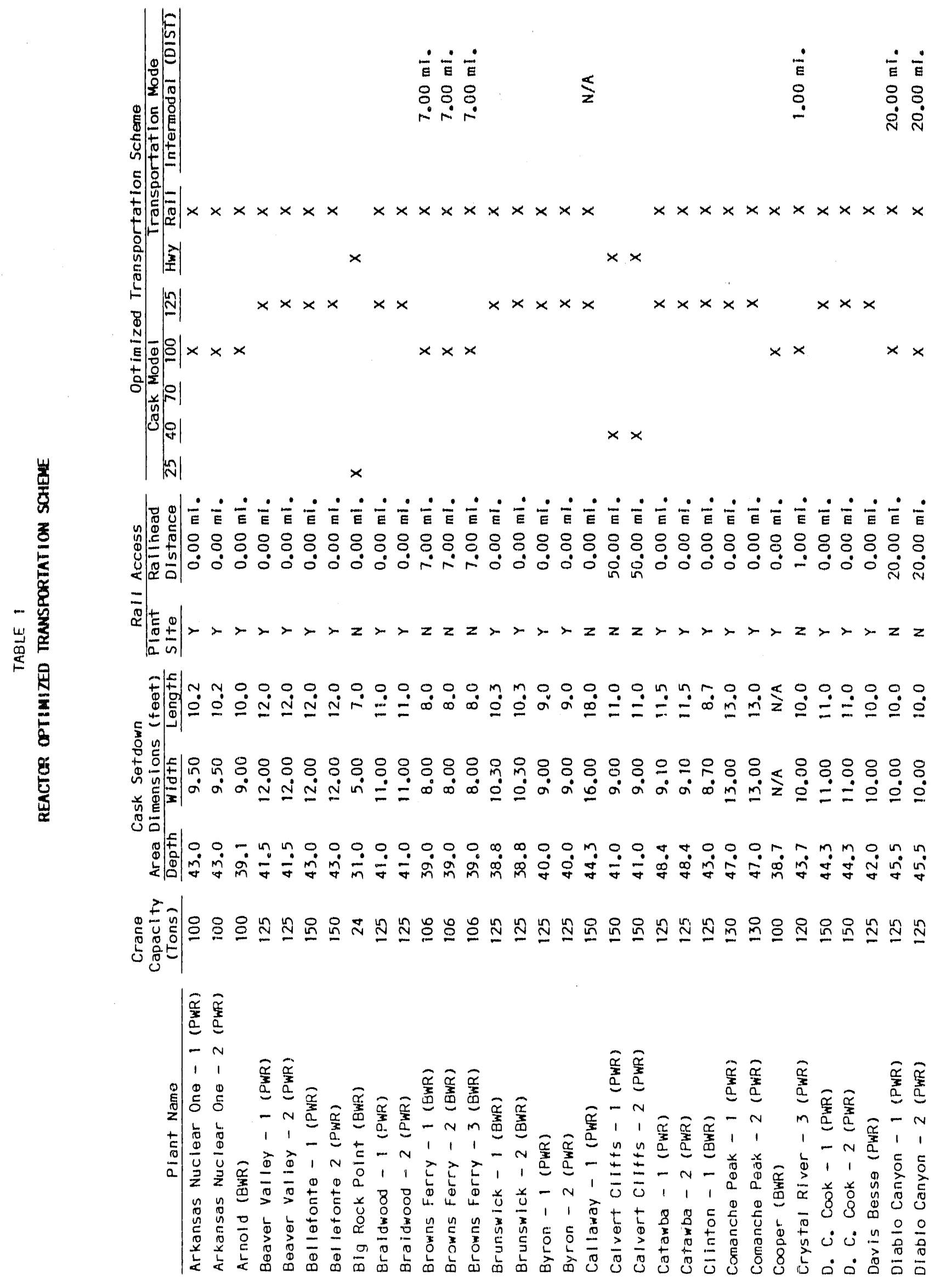




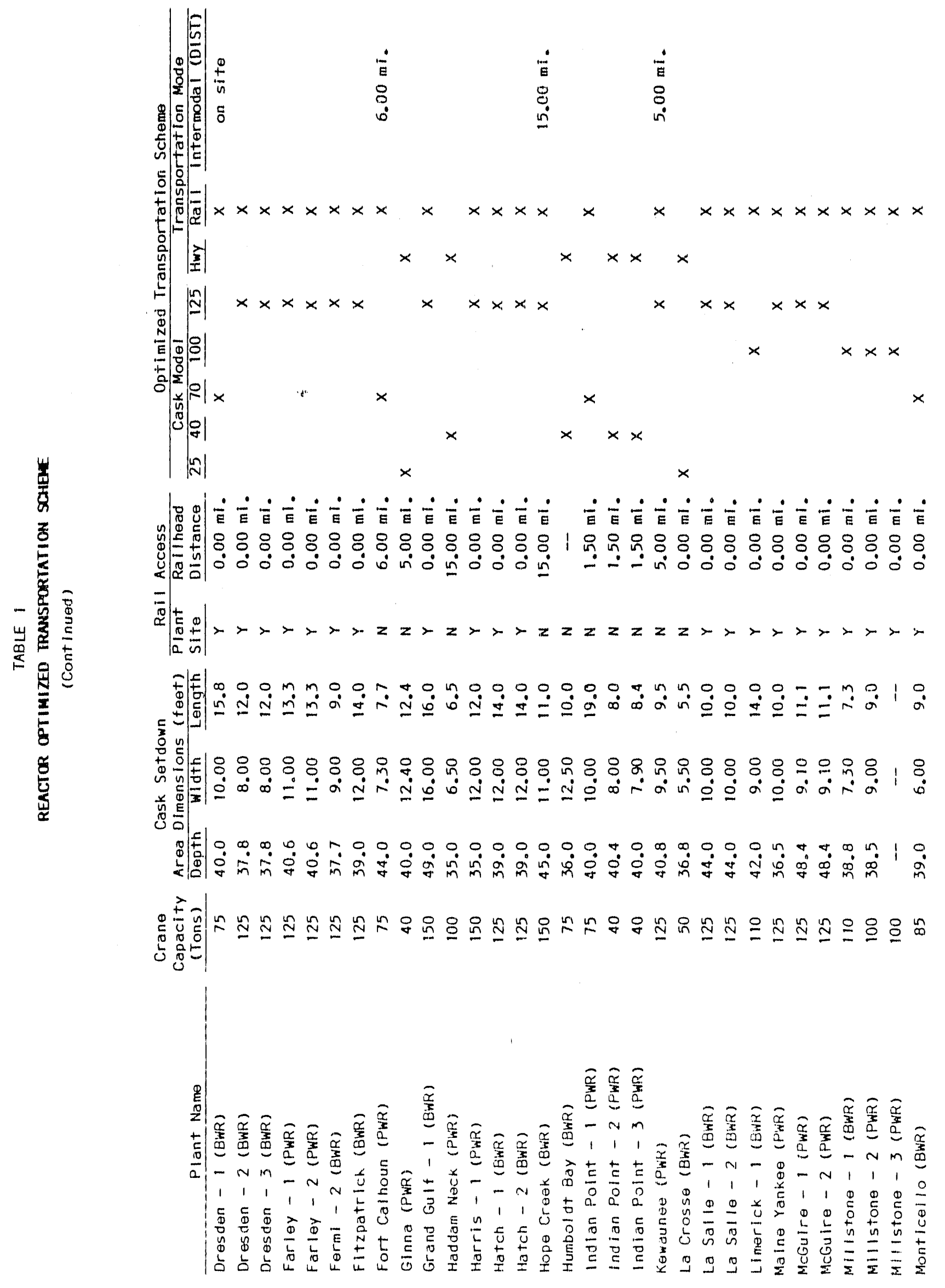




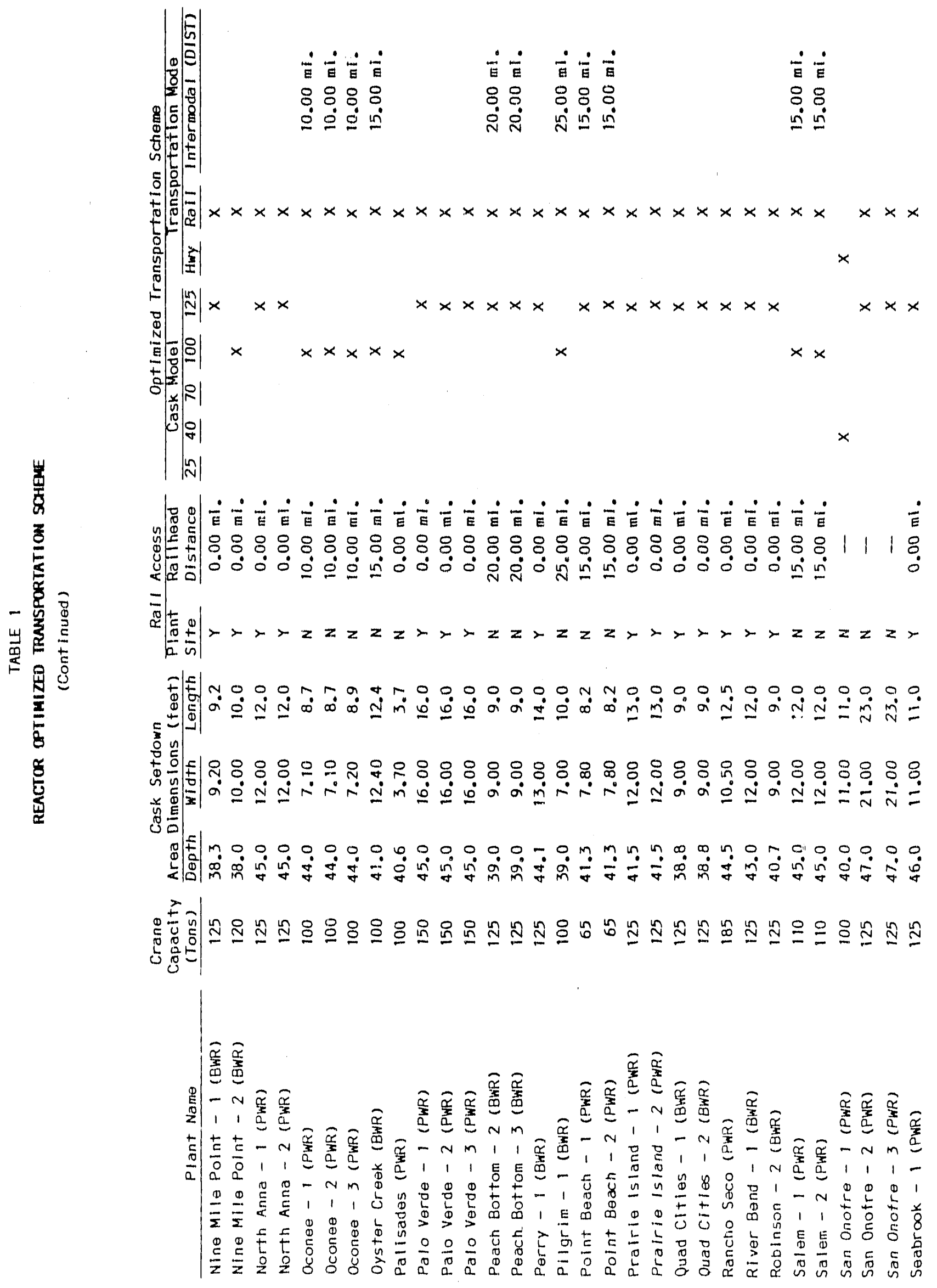




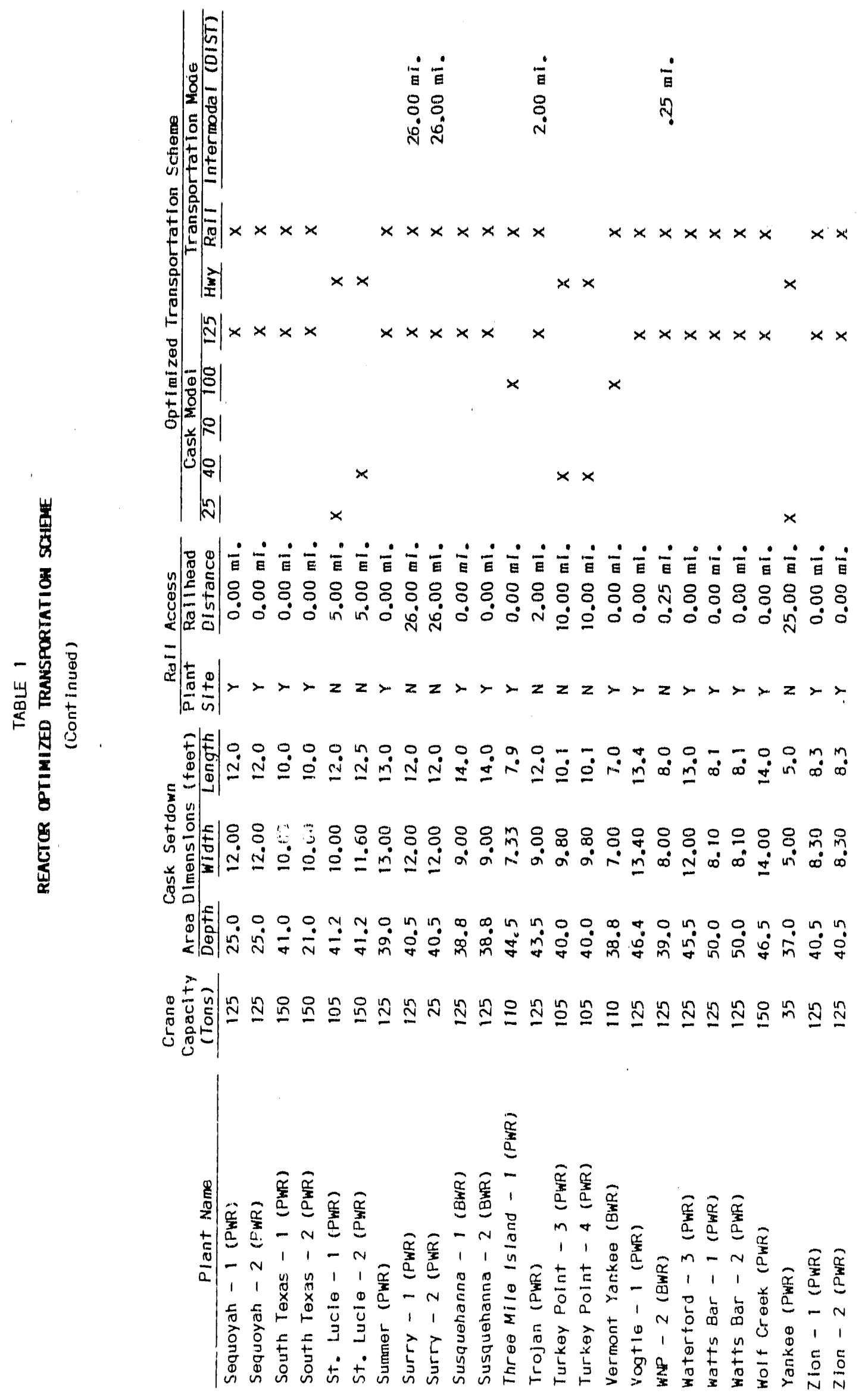




\section{TABLE 1 \\ REACTOR OPTIMIZED TRANSPORTATION SCHEME \\ NOTES}

1. Intermodal (heavy-haul to ratlhead or bargë/ratl) shipments have been assumed at:

Browns Ferry 1, 2, 3

Cal laway

Crystal River

Diablo Canyon

Hope Creek

Indian Point 1

Kewanuee
Oconee 1,23

Peach Bottom 2, 3

pilgrim

Salem

San Onofre 2, 3

Surry 1,2

WNP -2

2. Calvert Cliffs 1 and 2 cask drop reanalysis has been assumed to allow at least the use of a 40 ton cask.

3. Diablo Canyon limited by original design analysis.

4. Plant access restricts the use of the optimum cask at Ginna.

5. Dimensional limits restrict the use of optimum cask at Haddam Neck.

6. A 40 ton cask shipped on the highway has been assumed for Humboldt Bay.

7. Plant limitations at La Crosse restrict the use to only a 25 ton cask.

8. Presently, the rail spur at Palisades has been asphalted over: however, the assumption is that when necessary the rail spur could be made operational.

9. A 125 ton crane upgrade is being planned at Point Beach 1 and 2. 
TABLE 1

REACTOR OPTIMIZED TRANSPORTATION SCHEME

NOTES

(Continued)

10. An air pallet has to be utflized with a spent-fuel shipping cask and currently 11mits the use to a 2.5 ton cask at San Onofre-1. Reanalysis and use of a 40 ton cask has been assumed.

11. Cask drop analysis at St. Lucte 1 1 fmits the use to a 25 ton cask and rearlalysis is unllkely to increase 1 imit.

12. Roads surrounding the St. Lucie site are limited to $80,0001 \mathrm{~b}$ GVW.

13. Site Iimitations at Turkey Point 3 and 4 restrict the use to a 25 ton cask. 
EVALUATION OF THE NEED, FLASIBILITY, AND SITING OF THE MRS IN TENNESSEE

Append1x: PInancial Cost:

of the Integrated Monticored Retrievable Storage Option

\author{
Contractor Report \\ Prepared by \\ Institute for Energy Analysis \\ Oak Ridge Asuoctated UnIversities \\ Post office Box 117 \\ Oak Ridge, Tennessee 37831-0117
}

December 1985 
FINANCIAL COST OF THE INTEGRATED MONITORED RETRIEVABLE STORAGE OPTION

\section{Introduction}

The DOE case for integral montrored retrlevable storage (MRS) is not based on cost savings; the benefits clatmed for the MRS option are not easily expressed in financial terms and DOE has not tried to do so. Rather, DOE has compared the financial costs of the MRS with the profected costs of the entire DOE waste management program and then subjectively determined that the incremental financial cost to the Nuclear Waste Fund is an acceptable price for the various benefits. One benefit is a reduced need for at-reactor storage--costs borne directly by the utilities instead of Indirectly through the Nuclear Waste Fund. When credit is taken for this saving, MRS financlal costs are lower and it is this total financial cost to utilities which is to be weighed against the subjective benefits. DOE estimates the total cor of the I-MRS option to be $\$ 1.0$ to 1.9 billion.* This range ts solely a function of the range of assumed boundary conditions (1.e., repository media and at-reactor storage costs) and does not reflect the uncertainty of the estimates themselves. That 18, DOE has presented estimates for several situacions but has not presented information about the accuracy of its estimation techniques. Two questions are. relevant: How uncertain are the estimates and how appropriate 18 the range of assumed boundary conditions? This paper reports a review of DOE's cost estimates and an examination of these questions.

Although the accuracy of cost estimates for systems as large and complex as those evaluated here cannot be certain, we find no reason to question the accuracy of these estimates as a basis for decistonmaking. They are roughly consistent with estimates ty other DOE contractors. Furthermore, the additional systems costs incurred under the MRS option are

*DOE typically presents 1ts cost data 23 undiscounted totals. For our purposes this assumption, that the time an expenditure occurs does not matter, is not unreasonable; the options being evaluated do not materially change the timing of expenditures. At a discount rate of $3 \%$, the present worth costs are approximately 60 percent of the undiscounted totals. 
largely the costs of supporting an additional site and these costs are better known than are the costs of other major components of the waste management program. For instance, fuel consolidation costs are not well known. But In comparing systems with and without MRS, the cost and uncertainty of fuel consolidation is irrelevant; only the location changes. Thus, uncertainties in estimating net MRS costs are relatively smaller than are uncertalnties in estimating total system costs.

The range of situations or boundary conditions evaluated by DOE varles only two parameters: repository medium and at-reactor storage cost. Other relevant paraneters include need for at-reactor storage, transportation syster efficlency, and whether and where fuel consolidation takes place. Evaluation of DOE's assumptions suggests that need for storage has been overestimated, overstating the savings of at-reactor utility costs. MRS' impact on transportation cost is relatively insensitive to variation of the other parameters.

One major omission in DOE's estimates is compensation of the state and cominutity for the socioeconomic costs of the MRS facility; a plausible estimate of this cost $18 \$ 0.8$ billion over the life of the facility. The resulting net MRS cost rises to $\$ 2.2-2.8$ billion.

Altogether, this analysis suggests that MRS will cost about a billion dollars more than DOE has estimated. Using a net cost of $\$ 2.5$ billion and average burnup of 35,000 megawatt-days (thermal)/metric ton, MRS would cost $0.15 \mathrm{~m} 111 \mathrm{~s} / \mathrm{kilowat}-\mathrm{hr}$. for the fuel going into the first repository.

\section{MRS Cost Estimates}

Table 1 summarizes DOE's MRS cost estimates. Net cost to the Nuclear Waste Fund is $\$ 1.5-2.1$ billion, depending on repository medium. Transportation cost differences are negligible. Of the net cost, $\$ 0.5$ billion 18 storage costs; the remaining $\$ 1.0-1.6$ billion ts the cost of dupltcated and additional capabilities resulting from the additional site (DOE, Table 2.9).

Dividing the storage cost by $14,000 \mathrm{MTU}(1,000 \mathrm{MTU}$ of lag storage 18 included in the non-storage facilities) ylelds a unit cost of $\sim \$ 35 / \mathrm{kgU}$. Storage at the MRS B1te replaces at-reactor options costing 
Table 1. DOE Cost Estimates for MRS, Blllion 1985 Dollars

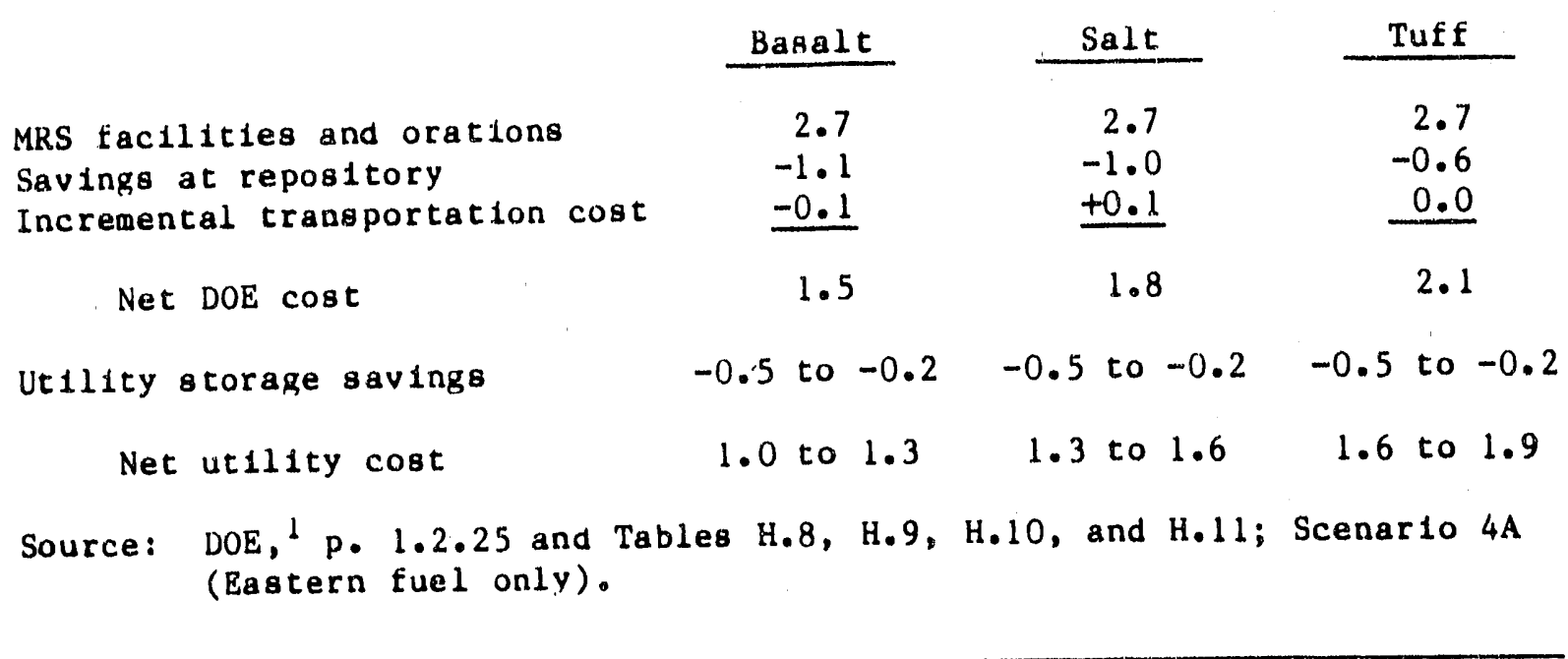

$\$ 50-125 / \mathrm{kgU}\left(\mathrm{DOE},{ }^{+}, \mathrm{p}, \mathrm{J} .26\right)$. Thus the highest MRS cost, from ut1lities' perspective, is a situation where the MRS site's storage capabilities do not replace needed at-reactor storage. DOE claims a credit of $\$ 0.2-0.5$ billion for at-reactor storage costs that MRS would obviate (4,000 MTU times, the range of storage costs cited above).

\section{Rellability of Estimates}

DOE's cost estimates could be wrong elther because of the many unknowns involved in a project of this magnitude (a random error), or because of a conscious or subconsclous systematic bias. Adding MRS to the waste management system involves moving some facilities from the repository to another site and duplicating other facilities at the new site. The duplicated facilities are largely support related--security, site preparation, laboratory and montcoring, cask recelving and handling--and we have substantial experience with these kinds of 1 tems. The large unknowns are the productiol scale hot cells and equipment for disassembly and packaging, which will be bullt at one location or the other, and the underground portion of the repository. Any uncertainties here zero out when the two alternative systems are compared. Therefore, random uncertainties as to 
differences between the alcernatives are likely to be small compared with the uncertainties about total system cost.

Systematic error is more difficult to evaluate. We can compare DOE's estimates with those made by other parties but 1 ts difficult to be sure one ts matching truly comparable estimates. This test 181 imited, too, by the necessity to use estimates by DOE contractors as the "Independent" values against which DOE estimates are compared. The estimates probably are not completely independent.

Table 2 compares estimates of transportation costs of MRS. The WestInghouse costs are for both repositorles and assume that all fuel 18 sipped first to the MRS site; the costs for transportation to the first repository alone cannot be separated out. The three sources are in agreement as to the relative unimportance of transportation cost differences.

Table 2. Comparison of Transportation Costs With and Without MRS, \$B11110na

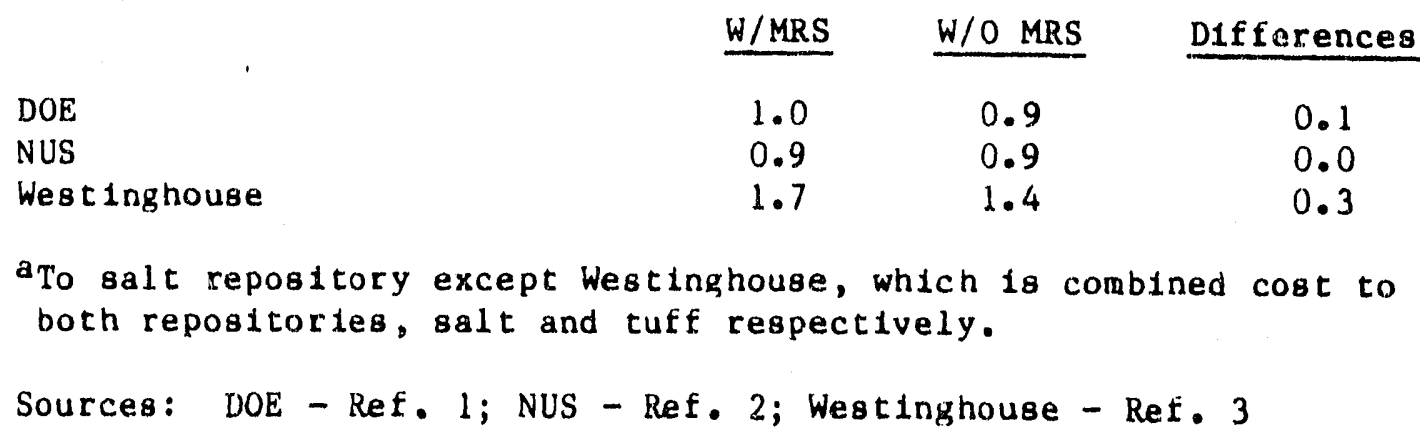

Johnson Associates provide the only detalled examination of the cost of fixed MRS fac 111 t1es and their operation. 4 The numbers in Table 3 must be viewed with caution as Johnson assumed a double-sized MRS serving both repositories. I estimate that $\$ 0.7$ b11110n of Johnson's MRS cost 18 as8oclated with the second repository and that the net cost for the one repos1tory case would be $\$ 0.7$ b11110n (compared with DOE's $\$ 1.2$ b11110n). Th1s comparison is hardly definitive but indicates (1) that the two sources 
Table 3. Comparison of MRS Costs and Repository Savings, $\$$ Billion

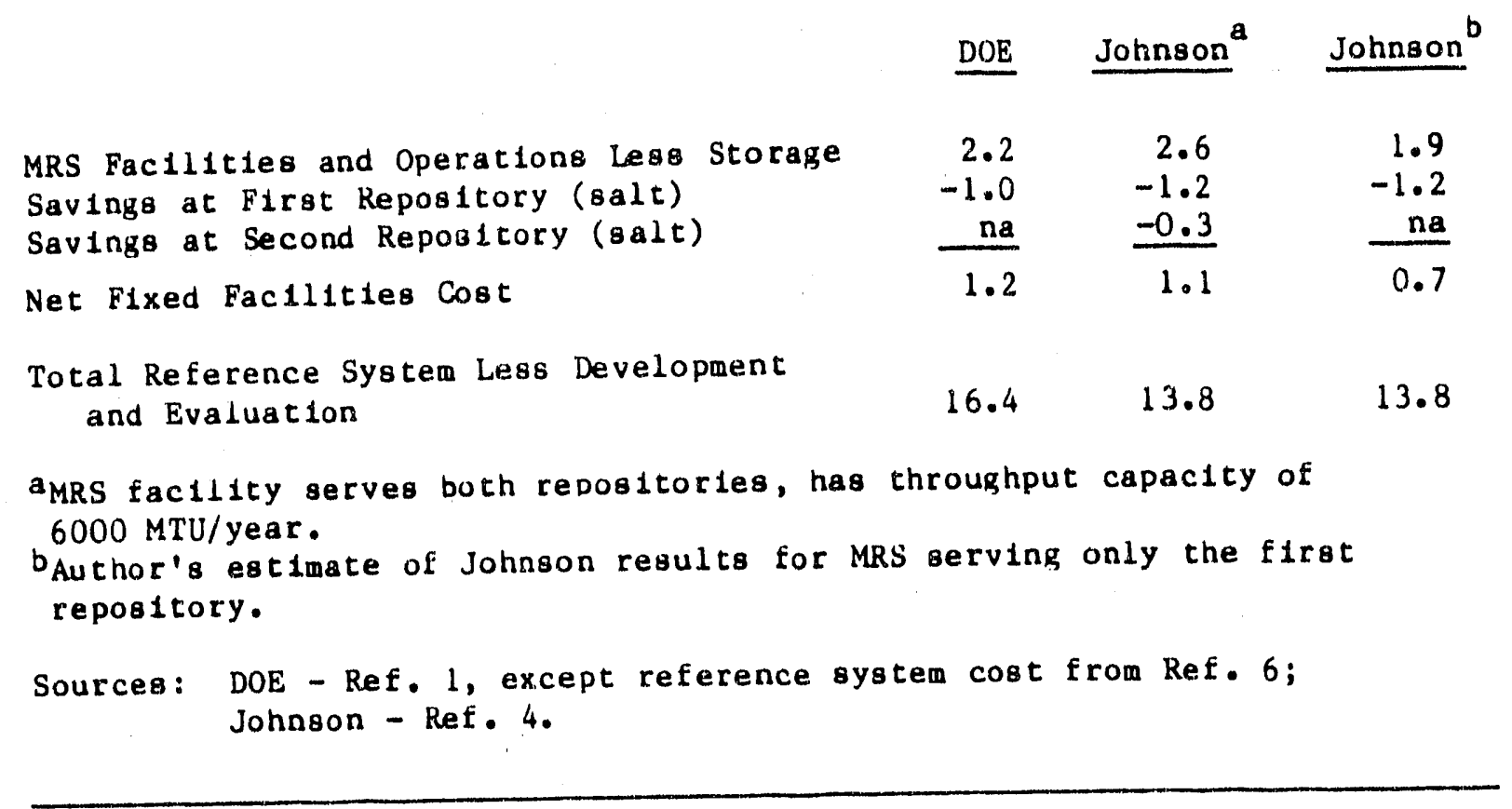

agree within a factor of two and (2) that DOE's estimate is not blased downward.

Effect of Boundary Condition Assumptions

The cost of the entre spent fuel management program w1ll depend on such factors as whether and where fuel is consolidated, the efficiency of the transportation system, and the need for out-of-pool storage. What effect do these factors have on the difference between system costs with and without MRS?

We do not have access to detalled computations with which to answer this question. Nevertheless, we can satisfactorily answer the question with simpler analyses.

Consider the transportation system. The effect of adding MRS to the system configuration is to Increase average travel distance by roughly 40 percent while decreasing the number of casks and trips on the MRS-torepository leg of the fourney. In DOE's analysis, these effects are 
approximately offietting. If DOE were to forego consolidation, much of the saving on the final leg would be negated. Tranoportation costs might increase proportionally to the discance increase, 40 percent or $\$ 0.4$ billion. This appears to be the upper limit. For instance, atreactor consolidation also negates the benefit of consolidation at MRS but reduces costs throughout the system by approximately the inverse of the consolidation rat108; the 40 percent increase because of distance to multiplied by a smaller base (no-MRS) transport cost. Transport system efficlenclea, too, negate the transportation cost benefits of MRS but reduce the base cost. Thus, transportation cost differences are small under any set of assumptions.

For fixed facilities and operations we can perform a similar analysis. Should DOE drop fuel consolidation from the system for whatever reason, the cost differential would be the same with or without MRS. Net MRS costs result from duplication; removal of consolidation is unlikely to significantly change that net $\cos t$.

Need for and cost of at-reactor dry storage 18 the most important variuble in assessing the cost of MRS to utilities. DOE places MRS-Induced utflity savings at $\$ 0.2-0.5$ billion. But the spent fuel forecast on which these savings are based appears dated and high. 5 DOE says MRS w1ll obviate 4,000 MTU of at-reactor storage. The forecast in Reference 5 shows $1,400 \mathrm{MTU}$ to be a mure reasonable estimate for the case with on-time repository startup (as DOE assumes). Using at-reactor storage costs in the midale of DOE's range Implies likely savings of only $\$ 0.1$ b1llion.

Should the repository be significantly delayed wishout an MRS delay, storage-related savings would increase. Note that DOE's anisunced intention to link repository and MRS schedules limits storage savings because a repository delay is likely to delay MRS deployment. Postulating an extended repository delay that somehow does not delay MRS, storage savings wight approach DOE's estimates for the on-time repository case, but this scenarto is an unlikely one.

DOE's cost estimates appareatly neglect state and community compensation, including, but not imited to, tax equivalency grants stintlar to those authorized for the first repository. The dak Ridge community has requested compensation that might amount to $\$ 10 \mathrm{mill}$ ion/year for 40 years. 
Comparable compensation for the state would yield a total cost of $\$ 0.8$ billion. This level of compengation would be a significant component of MRS cost, amounting to roughly one-third of the total net cost.

\section{Summary}

DOE understates MRS costs in two ways. Most importantly, it neglects state and local compensation. Compensation could easily cost $\$ 0.8$ billion over the MRS profect lifetime. DOE also overstates utilities' storage cost savings stemming from the earlier fuel acceptance possible with MRS. Instead of $\$ 0.2$ to 0.5 billion in savings, $\$ 0.1$ is a more 1ikely estimate. These changes raise utilities net MRS cost by about $\$ 1.0$ billion, for a total cost to utilities of $\$ 2.2$ to 2.8 billion, depending on repository (Table 4).

Table 4. Likely MRS Cost, Billion 1985 Dollars

\begin{tabular}{|c|c|c|c|}
\hline & Basalt & Salt & Tuff \\
\hline $\begin{array}{l}\text { Net DOE cost (from Table } 1 \text { ) } \\
\text { Compensation cost }\end{array}$ & $\begin{array}{l}1.5 \\
0.8 \\
\end{array}$ & $\begin{array}{l}1.8 \\
0.8 \\
\end{array}$ & $\begin{array}{l}2.1 \\
0.8 \\
\end{array}$ \\
\hline Revised net DOE cost & 2.3 & 2.6 & 2.9 \\
\hline Revised utility storage savings & -0.1 & -0.1 & -0.1 \\
\hline Revised net ut 111 ty cost & 2.2 & 2.5 & 2.8 \\
\hline
\end{tabular}

The median, $\$ 2.5$ billion, might be considered the most likely cost. This Increment 18 about 10 percent of DOE's estimated total program cost. ${ }^{6}$ For the fuel scheduled for the $\mathrm{f} 1 \mathrm{rst}$ repository, MRS adds $0.15 \mathrm{mills} / \mathrm{kWh}$ to 1 ts disposal cost. The MRS option 18 not cheap.

Against this substantial cost, Congress must weigh intangible benefits. DOE claims that the MRS option reduces interaction between the public and spent fuel transportation, that it allows transportation 
planners a 5-year head start, that 1t gives utilities earlier and firmer information on which to base their opent fuel management plans, and that $1 t$ decouples syotem components and allows greater operational flexibility, providing a cushion for various unforeseen technical or institutionat problems. In DOE's view, these direct benefits increase the likel thood that the repository can be built on schedule. Whether Congress w1ll agree with DOE that the benefits of having an MRS outweigh the costs remains to be seen. 


\section{References}

1. U.S. Department of Energy, "Monitored Retrievable Storage Submission to Congress," Volume 2, prellminary copy, November 1985.

2. NUS Corporation, "An Assessment of the Use of Half-Square Cans for the Management of Spent Fuel," NUS-4724, dratt, July 1985.

3. Westinghouse Electric Corporation, Phase 1 Study of Metallic Cask Systems for Spent Fuel Management From Reactor to Repository, WTSDTME-D85, draft, September 1985.

4. E.R. Johnson Associates, Inc., "Assessment of the Use of a MultiPurpose and Centralized Facility for the Dlsassembly and Packaging of Spent Nuclear Fuel to Support the Various Segments of the DOE Waste Management System, JAI-254, draft, May 1985.

5. Nuclear Assurance Corporation, "Spent-Fuel Discharges and Additional Spent-Fuel Storage Needs," October 1985.

6. U.S. Department of Energy, "Analysis of the Total System Life Cycle Cost for the Civilian Radjoactive Waste Management Program, DOE/ RW-0024, Apr 111985. 
EVALUATION OF THE NEED, FEASIBILITY, AND SITING OF THE MRS IN TENNESSEE

Appendix: Rod Consolidation and the MRS

\author{
Contractor Report \\ Prepared by \\ Institute for Energy Analysis \\ Oak Ridge Associated Universities \\ Post office Box 117 \\ Oak Ridge, Tennessee 37831-0117
}

December 1985 


\section{DRAFT}

TASK 4. ROD CONSOLIDATION

1. Waste handling aysten options and the role of rod consolidation.

It lo difficult to grasp the role of any element of the spent fuel disposal system because of the diversity and complextty of fuel handing options. The options are displayed in general terms in Figure 1. The most Important of these optlons are the following:

-- Where to atore the spent fuel--at-reactor in a pool, at-reactor dry, at an MRS, or in the repository.

-- How long to store the fuel before final disposal.

-- How to transport the fue1--truck, rall or some combination.

-- Whether to consolidate* the fuel and where.

Rod consolidation has the general advantage of being able to lncrease the capacity of a given contalner or storage space. This parameter affects very broadly the costs and Impacts of the spent fuel management system, as outlined in Section 1.3.

1.1 Ceneral description of rod consolidation options. At-reactor consolidation

Spent fuel is atored as fuel elements in at-reactor storage pools. As the storage space 1s filled, ut1lities generally seek NRC permisalon to "rerack," providing a more compact arrangement of spent fuel elements. Most utilities have elther already begun reracking or are expected to do so.

As spent fuel Inventories costinue to increase, ut1lities will reach a point where they w1ll have to elther (a) enlarge the pools, (b) ship spent fuel off-site, (c) bulld on-site dry storage facilities, or (d) consolidate the fuel and either return it to the pool or place it into dry storage. The Atomic Industrlal Forum has created a Working Group on Rod Consolidation that is focusing on rod consolidation isaues including

* Consolidation is the disassembly of nuclear fuel assembiles followed by repositioning of the fuel rods lnto a closely packed bundle. 


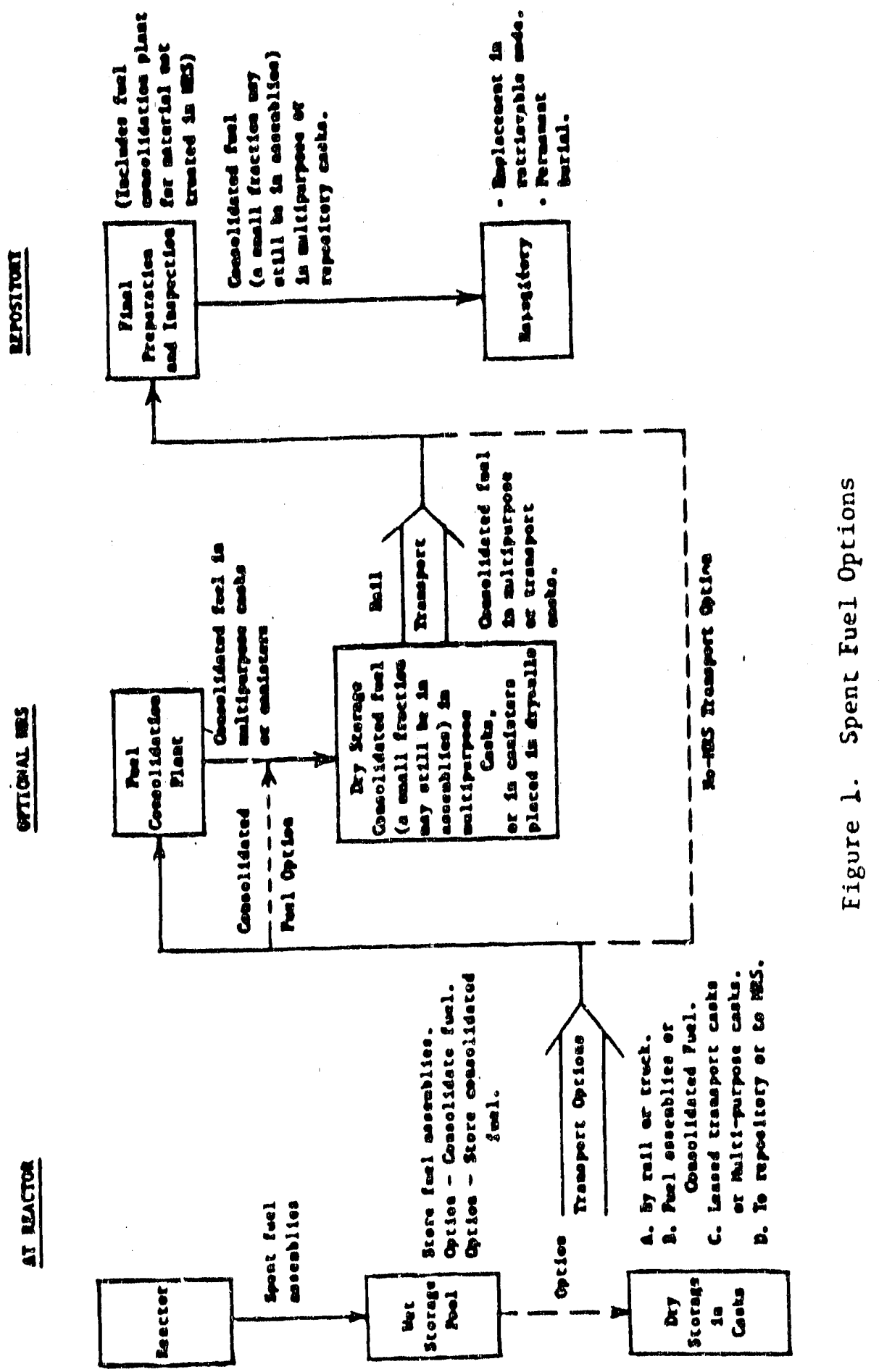


Interface questlons such as acceptance criterla for dry storage or transfer to DOE. The Working Group has generated a list of reactor sites that w1ll have to consider rod consolidation prior to 1998, shown in Table 1. The 1 ist includes 27 reactors.

Rod consolidation operations in reactor storage pools have been demonstrated, and other demonstrations are planned (Section 1.2). Several nuclear service companies currently offer to consolidate fuel in a atorage pool under contract. The contract price for such service is expected to be in the range of $\$ 10-15 / \mathrm{kgU}$. Contrasted with expectations of $\$ 70$ to $\$ \$ 00 / \mathrm{kg}$ for on-site dry storage (unconsolidated), there ls clearly a cost incentive to consolidation when running out of pool storage space.

The consolidation has economic merit for elther continued 1n-pool storage or for on-site dry storage, cutting the cost of the latter option nearly in half as compared to unconsolidated storage. Consolidation at an MRS.

Westinghouse/Parsons performed an assessment of process alternatives for an MRS fuel consolidation factlity rated at $1800 \mathrm{MTU} / \mathrm{yr}$. This study considered both wet and dry alternatives. The dry horizontal facility operated remotely in a hot cell was considered most promising. Th1s type of facility bears some resemblance to fuel disassembly equipment that might be assoclated with a fuel reprocessing plant.

Consolidation at a repository

The approach would be simllar to that for an MRS.

\subsection{Experience to date with rod consolidation.}

Pacific Northwest Laboratory has suminarized the status of rod consolidation technology. ${ }^{2}$ The operation was demonstrated with four PWR fuel assemblies at the Oconee Nuclear Station (1982) and one PWR at Maine Yankee (1983). Add1tional demonstrations have been programmed under the sponsorship of DOE, EPRI, TVA and several Investor-owned utilities. Wet storage of the consolidated fuel 1s underway. Dry storage of consolidated spent fuel is to be part of a dry storage demonstration sponsored by Virginia Electric Power Company and DOE at Idaho Falls.'

The experfence gained with the development work thus far is favorable, and prospects for having this technology licensed by NRC are 
Table 1. Reactors Potentlally Requiring Additional On-Site Storage Capabilitles Prior to 1998

\begin{tabular}{|c|c|c|}
\hline Un1t & Company & $\begin{array}{l}\text { Anticipated } \\
\text { Loss of FCR } \\
\text { Capability }\end{array}$ \\
\hline San Onofre 1 & Southern Cal. Ed. & 1982 \\
\hline Surry $1 \& 2$ & VEPCO & 1985 \\
\hline Millstone 2 & NNEC & 1986 \\
\hline Pal1sades & Consumers Power & 1987 \\
\hline Grand Gulf 1 & M1ss1ss1pp1 P\&L & 1988 \\
\hline La Salle $1 \& 2$ & Commonwealth Edison Company & 1988 \\
\hline M111stone 1 & NNEC & 1988 \\
\hline Robinson 2 & Carolina Power and Light & 1988 \\
\hline Peach Bottom $2 \& 3$ & Philadelphia Electric & 1989 \\
\hline Oconee $1,2, \& 3$ & Duke Power & 1990 \\
\hline Pilgram & Boston Edison Company & 1990 \\
\hline Vermont Yankee & Vermont Yankee & 1990 \\
\hline Brunswick $1 \& 2$ & Baltimore $G \& E$ & 1992 \\
\hline Calvert Cliffs $1 \& 2$ & Baltimore $G \& E$ & 1992 \\
\hline J. Fitzpatrick & New York Power Authority & 1992 \\
\hline LaCrosse & Dalryland & 1992 \\
\hline D. Besse 1 & Toledo Edison & 1993 \\
\hline Indian Point 3 & New York Power Authority & 1993 \\
\hline Mont1ce11o & Northern State & 1993 \\
\hline Oyster Creek & GPU & 1993 \\
\hline Source: Atomic Industrial Forum & & \\
\hline
\end{tabular}


considered good. The major concern that must be dealt with in future work is the control of radioactive crud that may become suspended in the storage pool, impalring vislbility and creating low-level wastes. Another concern, that can be alleviated by consolidating only spent fuel that has been allowed to decay for about 10 years, is the extremely unlikely accidental loss of water from the pool leading to overheating; the aged fuel has a lower heat generation rate and would heat to a lesser extent.

\subsection{Advantages/disadvantages of rod consolidation.}

The generic advantages of rod consoldation are as follows:

-- Substantially reduces the volume required to store or transport a glven weight of fuel, to about half the volume required for fuel elements.

-- The reduced volume reduces the costs of wet atorage, dry storage and transportation.

-- There are a reduced number of shipments, reducing radiation exposure and other transportation impacts.

The generic disadvantages are as follows:

-- Provision must be made to deal with a higher amount of heat generation per unit volume.

-- Provision must be made to deal with secondary low-level wastes released during consolidation--non-fuel bearing hardware and crud.

-- There 18 radiation exposure during the consolidation operation.

- The costs In some cases may be greater than the benefits.

The advantages of consolldating spent fuel at the reactor site are as follows:

-- Where pool storage volume is $11 \mathrm{~m} 1 \mathrm{ted}$ and DOE 18 not ready to accept the spent fuel, consolidation 18 likely to be the lowest cost strategy.

-- The technology appears to be within reach, and competitive suppliers providing compacting services appear to be avallable.

- A number of utilities appear to be wllling to try 1t.

-- At-reactor consolidation minimizes subsequent transportation and storage costs and Impacts. 
The disadvantages appear to be as follows:

- Many utilicles may be unwilling to diversify their activities Into this area.

-- Where ample pool storage volume is avallable, it may not be percelved as the lowest cost option.

- Technical problems may develop at some reactors with radioactive crud, personnel exposure, accidents, etc., making this an unattractive option.

-- DOE Interface requirements may not be stable, Implying some f lnancial risk.

The advantages of consolidating spent fuel at an MRS are as follows:

-- It minimizes subsequent storage and transportation costs and Impacts.

-- Rod consolidation at a centralized facility should lead to economics of scale and uniform adherence to repository interface requirements.

The disadvantages appear to be as follows:

-- Lack of demonstrated low-cost, worker-frlendly technology (low radiation dose).

-- If many ut1lities undertake to consolidate fuel rods at reactor pools, an uncertain throughput requirement. (Low capacity utilization would increase unit costs.)

-- Aggregated benefits may not exceed increased cost.s.

The advantages of consolidating spent fuel at the repository are as follows:

- It minimizes emplacenent costs in that fewer repository casks must be fabricated and emplaced.

The disadvantages appear to be as follows:

-- Lack of demonstrated low-cost, worker-friendly technology.

-- Aggregated benefits may not exceed Increased costs. 
2. Revlew of wate handling plans and studies.

2.1 The DOE Mraton Plan ${ }^{3}$ and MRS Needs and Feasibility Study ${ }^{4}$

The DOE Mission Plan is based on the consolidation of spent fuel roda at the MRS. Fuel is then stored in relnforced concrete casks weighing 220 tons (loaded) and containing 20 tons of fuel rods. The incremental cost of storing these rods at the MRS 18 sald to be less than $\$ 20 / \mathrm{kg}$. The report describes the DOE-utflity cooperative program to develop at-reactor consolidation and states there w11l be some development of equipment sulted to fuel consolidacton at an MRS.

The needs and feasibility analysis included in Volume 2 of the submission to Congress gives estimates suggesting a storage cost closer to $\$ 35 / \mathrm{kg}$. A Prototyp1cal Consolidation Demonstration Profect 18 to develop and demonstrate dry consolidation and provide design data for the MRS production scale factlitles, based on Hestinghouse technology.

The Westinghouse fuel consolidation technology is described in references 5 and $h$. It Le a horlzontal, dry, "pull-fuel" type of system operated in a hot cell with a processing capability of $1800 \mathrm{MTU} /$ year. The cost cla1med by Westinghouse, $\$ 2.2 / \mathrm{kgU},{ }^{7}$ is substantially below the cost of at-reactor consolidation and below the cost of MRS consolidation Inferred from reference 4 , Table 1.

\subsection{The PROA Reports.}

DOE sponsored a sertes of studies in response to a Program Research and Development Announcement (PRDA). These reports present Innovative technology applicable to spent fuel handling and disposal. 
Table 1. Cost of Fuel Consolidation

A. Total System Cost, B11110n

Computed from MRS costa

Computed from repository savings - basalt

1.6

- alt

1.4

- Luff

1.3

.9

B. Unit $\operatorname{cost}, \mathrm{c} \$ / \mathrm{kgU}$

Capital Operating Total

Computed from MRS costa

Computed from repository savings ${ }^{b}$ - basalt

$13.68 \quad 16.71 \quad 30.39$

$11.31 \quad 14.66 \quad 25.97$

$\begin{array}{llll}\text { - salt } & 12.01 & 12.26 & 24.27\end{array}$

$\begin{array}{llll}\text { - tuff } & 9.08 & 8.60 & 17.68\end{array}$

ascenar10 3A, "Waste hand11ng" only; excludes "S1te" and "Support and

Utilities" as these cannot be allocated between consolidation and storage.

If attributed to consolidation, these components add $\$ 0.7$ billion or $\$ 12.93 / \mathrm{kgU}$ to the total. Also excludes waste package costs of $\$ 0.50 / \mathrm{kg}$ for basalt and salt or $\$ 1.25 / \mathrm{kgU}$ for tuff.

${ }^{b}$ Difference between Scenarios 1 and $3 \mathrm{~A}$.

CAssumes capital costs spread evenly over 62,000 MTU over 30 years at $3 \%$ discount rate.

Source: Ref. 4, Tables H.7 and H.9.

West1nghouse-Tennessee Valley Author1ty-Flor1da Power \& Light

Company. 8

This study bullds on the previous Westinghouse references ${ }^{5-7}$

and represents a system study with varlous alternatives. The principal focus is on flexible large cast steel casks useful for storage and transportation, or useful for storage, transportation and emplacement in a repository. These universal casks have attractive features for minimizing spent fuel handling, and for some scenarios, cost. The largest metal casks consldered can handle up to

$24 \mathrm{PWR} / 52$ BWR assemblies or fuel rods from $48 \mathrm{PWR} / 104$ BWR assemblies. 
E.R. Johnson Associates ${ }^{9}$

Th1s study develops data and costs for a number of system opt1ons with or without an MRS.

Transnuclear 10

This study focuses on the conceptual design of extra large storage and transport casks with capac1tles up to 57 PWR/148 BWR latact assemblies or $117 \mathrm{PWK} / 293$ BWR consolidated assemblies. The large capacity is achleved partly by using thermally conducting baskets within the cask and external cooling fins. The report also describes a transportable dry fuel consolidation rig sultable for temporary operation at a reactor site. This rig has a clalmed capacity of $1.5 \mathrm{MTU} / \mathrm{day}$.

GA Technologies

This study focuses on a universal canister sultable for contalning 3 PWR/6 BWR fuel assemblles or consolidated fuel rods from up to $8 \mathrm{PWR} / 16$ BWR assemblies. Up to 6 canisters can be fitted into a shippling or storage cask. Th1s report has more neutronic-thermal analysis as a function of fuel exposure time from discharge than other reports in this series. NuS Corporation ${ }^{12}$

The study focuses on the efficacy of half-square cans to tncrease the carrying capacity of truck casks. The study concludes that a legal weight truck cask for 6 PWR/16 BWR consolidated fuel elements 18 feasible and NUS states that the avallability of this technology enhances the attractiveness of at-reactor consolidation since a feasible truck transport scheme 18 avallable.

\subsection{The NAC itudy Reporta. ${ }^{13}, 14$}

The Nuclear Assurance Corporation has performed some computations and analysis for the University of Tennessee's MRS assessment project. The first of these reports reviews DOE's projectlons of spent fuel discharges and finds them to be high. This report also develops profections of the 
spent-fuel storage capacity short-fall and shows that rod consolidation can substantially reduce the projected needs for (at-reactor or at-MRS) storage capacity.

The second report estimates the costs and Impacts of optimized spent fuel transportation schemes, considering also whether fuel 1.s consolidated and/or whether there 18 an MRS. The data indlcate that relatively large econonles are possible from optimized transport (preference for ratl and large casks) and smaller economies from rod consolidation. The report considers up to 125 ton rall casks capable of handling 31 PWR/72 BWR fuel elements or consolidated fuel from $56 \mathrm{PWR} / 122$ BWR fuel assemblles.

\subsection{Other relevant studles and reports.}

E.R. Johnson Associates conducted a study comparing fuel bundle dlsassembly and close packing of fuel pins against 4 other alternative spent fuel management schemes. Conceptual plant designs were prepared and evaluated. The disassembly-consolidation approach was favored over the others, principally because 1t had the most favorable economics. 15

K.L. Huppert, 16 Gesellschaft zur Wiederaufarbeltung von Kernbrennstoffen mbH, reported that more than 80 tonnes of spent LWR fuel had been disassembled underwater at Karlsruhe prlor to reprocessing. "In spite of the fact that burnups were high (up to $39,000 \mathrm{MWd} / \mathrm{t}$ ) and that pulling the pins out of the spacers 1s a rude treatment, practically no breakage of pins has occurred."

3. Discussion and overall conclusions.

\subsection{Desirability/undesirability of rod consolidation.}

The work performed to date has uncovered certain benefits from rod consolidation and certaln costs. The benef1[8, which are more clearly defined than the costs, include:

- Increasing the capacity of at-reactor storage pools.

- reducing the number of packages for spent fuel storage, transportation and burial.

- reducing the radiation dosage in transportation, and the transport rloks and visual impacts. 
The costs, not well defined at present, include:

-- economic costs of consolidation in a manner consistent with occupational safety.

- Increased radiation dosage in the consolidation operation and in disposal of byproduct low-level wastes to be traded off against reduced radiation exfosure in transportation and during final disposal at the repository.

-- risks of incidents/accidents during consolidation.

The desirability of rod consolidation at certaln reactor pools that have limited capacity may ha much stronger than the desirability of rod consolidation at an MRS. If many utilities voluntarily elect to consol1date, the incentives to consolidate the residual fuel at the MRS are weakened because un1t costs would 1ncrease.

\subsection{Role of the MRS.}

The technical functions of an integral MRS in the national waste program can potentially include the following:

-- acceptance of spent fuel from utilities that have exceeded their onsite storage capacity.

- preparation and packagling the spent fuel for emplacement in a repository.

- rod consolldation.

-- storage of spent fuel.

-- shipment of spent fuel packages to the repository at an optimal rate and in an optimal mode.

The first two technical functions are clear-cut and require no discusston here.

Regarding rod consolidation, DOE has not presented any clear-cut analysis that demonstrates that the rod consolidation (carried out at the MRS) benefits outweigh the costs. Rod consolidation at the MRS 18 simply an option and not a need.

The storage function may not be as simple as th appears. Repository interface requirements may change with time so that packages would have to be reworked. With the current trend toward large packages of spent fuel (consolidated or unconsolidated) there may be increased incentives for 
ex-reposttory storage of these packages unt1l the heat generation rates have somewhat decayed. Some European countrles plan to store spent fuel on the order of 40 years to $11 \mathrm{mit}$ repository heating. DOE has apparantly not studled this aspect of the storage/consolidation question, but conoalidated fuel packages tend to have about twice the heat generation of unconsolidated packages. Consequently, at-MRS storage needs may be somewhat greater than currently profected.

The final technical function 1 isted 18 clear-cut and requires no discusston here.

The unresolved 18sues and questions to be addressed by DOE are covered in the next section. Further development, demonstration and analysis wust be conducted over a perlod of years to clarify these lssues and lead to declsions that are optimal both for the nation and for Tennessee.

\subsection{Conclusions and questions to be addressed by DOB.}

The DOE research, analysis and studies to date do not support the position that rod consolidation should be conducted at an MRS.

Of all the operations to be assoclated with the MRS, the consol1dation operation has the greatest potential to generate accidents, unforeseen personnel exposure, byproduct radloactive low-level wastes, and embarrassing cost overruns. This part of the MRS profect should not be adopted unttl such time that DOE's development, demonstration and analyols has clearly established the destrability of this part of the operation. DOE might consider the alternative of crediting utilities an approprlate fee for dellverling consolidated fuel rods. Apparently many utilities already have some incentives to consolidate spent fuel. If this can be done in a manner acceptable to the health and safety of workers at the plants and the public, it would reduce the need for major DOE consol1dation facilities.

DOE should be encouraged to continue 1 ts development on both dry and in-pool rod consolidation so that the costs and undestrable side effects (if any) can be better defined.

DOE should be encouraged to continue to refine 1 ts systems studies to 1mprove the cost-beneftit analysis of rod consolidation. A related parameter that should bear additional study is the optimal storage mode 
and time, prior to emplacement of spent fuel linto the repository. Present trends toward higher burnup, fuel consolidation and large fuel packages may call for storage of spent fuel for more than 10 years from time of discharge froin the reactor on average. 


\section{References}

1. Ralph M. Parsons Company, Westinghouse Electrlc Corporation, Golder Assoclates, Design Study DS-9, "Spent Fuel Conoolidation Optimization Study," July 1985.

2. W.J. Batley, "Status of Rod Consolidation," Pacifle Northwest Laboratory, PNL-5122, Apr 111985.

3. U.S. Department of Energy, "Mission Plan for the Clvilian Radloactive Waste Management Program," DOE/KW-0005, Volume 1, June 1985.

4. U.S. Department of Energy, "Monttored Retrlevable Storage Submisaton to Congress," Volume 2, Environiental Assessment for a Monitored Retrievable System Fac1lity, preliminary copy, November 1985.

5. W.H. BLlssell, "PWR and BWR Conceptual Spent Fuel Consolidation Equipment for a Monitored Retrlevable Storage Fac1l1ty," December 17, 1984.

6. Ralph M. Parsons Company, Westinghouse Electric Corporation, and Golder Associates, "Spent Puel Consolidation Optimization Study," Design Study DS -9 , July 1985.

7. West:1nghouse Electric Corporation,"Preliminary Cost Analysis of a Universal Package Concept in the Spent Fuel Managenent System," WTSD TME-032, September 1984.

8. Westinghouse Electric Corporation, Tennessee Valley Authority and Florida Power \& Light Company, "Phase 1 Study of Metallic Cask Systems for Spent Fuel Management from Reactor to Repository," 3 volumes, WTSD-TME-085 (draft), September 1985.

9. E.R. Johnson Assoctates, Inc., "Assessment of the Use of a Multipurpose and Centralized Factlity for the Dlsassembly and Packaging of Spent Nuclear Fuel to Support the Various Segments of the DOE Waste Management System," JAI-254, Draft, May 1985.

10. Transnuclear, Inc., "A Study of Extra Large Storage Casks," E-7228, Draft, 1985.

11. G.A. Technologles, "Commerctal Radloactive Waste Management System Feas 1b1lity with the Untuersal Canister Concept," 2 volumes, Draft, July 1985.

12. NUS Corporation, "An Assessment of the Use of Half-Square Cans for the Management of Spent Fue1," NUS-4724, July 1985.

13. Nuclear Assurance Corporation, "Spent-Fuel Discharges and Additional Spent-Fuel Storage Needs," Draft, October 1985. 
References (continued)

14. Nuclear Assurance Corporation, "Optimized Transportation Scheme," Draft Report, October 1985.

15. E.R. Johnson Associates, "Assessinent of the Impacts of Spent Fuel Disassembly Alternatives on the Nuclear Waste Isolation System," BMI/ ONWI-533, July 1984.

16. K.L. Huppert, "Spent Fuel Storage--Philosophies and Expertence," Proceedings of the NEA Seminar on the Storage of Spent Fuel Elements, Madrid, June 1978. 
EVALUATION OF THE NEED, FEASIBILITY, AND SITING OF AN MRS IN TENNESSEE

\title{
Appendix: Stting Review, Monttored Retrlevable Storage (MRS)
}

Why Tennessee?

\author{
Contractor Report \\ Prepared by \\ Instlitute for Energy Analysis \\ Oak Ridge Associated Universities \\ Post office Box 117 \\ Oak Ridge, Tennessee 37831-0117
}

December 1985 
SUMMARY

The Director of the U.S. Department of Energy's Office of Civilian Radioactive Waste Management has nominated, as required by the Nuclear Waste Pollcy Act of 1982, a preferred site and two alternative sites for an MRS facllity. All three sites are in Tennessee. The three sites were named after an evaluation of ways to minimize shipment miles for transport of the spent nuclear fuel and an extenslve task force review of potential sites and site characteristics. The Director exercised his judgment in selecting among the final five candidate sites. A fundamental premise of the site screening process was that the MRS facllity relles on englneered contalnment of spent fuel, does not have site specific requirements or risks, and therefore that the screening process can be appropriately used not to discard unsultable sites, but to focus on the most desirable sites.

The desirability of minimizing total shipment miles and the associated risks and costs was taken to be the "primary criterion for discriminating among possible MRS sites." With many decisions on systems integration yet to be made, it is not convincing that the 390,000 square mile "preferred siting region" defined will truly result in minimizing total shipment miles or, in fact, that total shipment miles should even be an overriding consideratiol.

However, the site screening then focused on sites within the "preferred siting region" and for which information was readily avallable (sites which were previously considered for NRC 11censing or were DOE-owned). Sites under 1100 acres, sites with other nuclear facilities, and privately-owned sites, were successively eliminated as the technical data review did not reveal any of the candidates with severe physical limitations. All of the physical and technical data gathered fail to provide definitive discrimination among the sites considered.

Political acceptability and percelved expediency in peritting and construction seem to have been the primary criteria on which site selection was ultimately based. The preferred site is in an area with a long history, close familiarity, and relative comfortableness wh th nuclear factitites. In this case, political criteria seem to provide entirely valid reasons for selection, if indeed, the faciltty is environinentally benign and has no site-specific requirements or risks. 
MRS - WHY TENNESSEE?

The Nuclear Waste Policy Act of $1982^{1}$ required that by June 1, 1985 the Secretary of Energy submit to Congress a proposal for the construction of one or more monitored retrlevable storage (MRS) facllities for high-level radioactive waste and spent nuclear fuel. The Act further required that this proposal include site-specific designs for at least three alternative sites. The only limitation spelled out for these sites was that "no monitored retrievable storage facility... may be constructed in any state in which there is located any site approved for site characterization" (as a permanent repository).

In April 1985, the Secretary announced the locations of three such sites, a preferred sice and two alternatives--all in Tennessee. The preferred site is on the Clinch River within the city limits of Oak Ridge in Roane County. The alternative sites are respectively in the Roane County portion of Oak Ridge and in Trousdale and Smith Counties near Hartsville. This paper reviews the ifterature which describes the formal studies of the site selection process and comments on other factors which seem to have influenced the final decisions. The objective here is to clearly establish what the selection criterla really were and how it came to pass that three specific Tennessee sites were named.

The site screening and identiftcation process is elaborated in three reports. The first (PNL-5424), ${ }^{2}$ prepared by Batelle's Pactfic Northwest Laboratory in April 1985, describes an analysis which attempts to minimize transportation requirements. It identifies a roughly circular region of 700 miles diameter centered approximately on Oak Ridge, Tennessee which it characterizes as the "preferred siting region." The second report (hereafter DOE/NBB-0071) ${ }^{3}$ describes the efforts of a site screening task force to identify and evaluate potential MRS sites within the preferred siting region.

The site screening and evaluation process is summarized by the DOE Office of Civilian Radioactive Waste Management in DOE/RW-0023. ${ }^{4}$ This last document describes how the three final sites were selected from among the 11 candidates which were evaluated by the site screening task force. 
"The Director, Office of Civilian Radioactive Waste Management (OCRWM), Department of Energy (DOE), has identified the Clinch River Breeder Reactor Site, the DOE Oak Ridge Reservation and the Tennessee Valley Authority (TVA) Hartsville Nuclear Plant site as preferred and alternate sites, respectively, for development of site-specific designs as part of the proposal for construction of an integrated Monitored Retrievable Storate (MRS) facility.... The Director expects to propose to Congress that an MRS be constructed at the preferred site. This judgment could change based on information to be developed between now and January 1986.... The Director's fudgment is based on the results of a vigorous site screening and evaluation process...." (DOE/RW-0023, P. 1)

The final DOE Report on Screening and Identiflcation of Sites for a Proposed Monitored Retrievable Storage Facility begins with these words and makes it clear that final site selection was based on the Director's judgment. The site screening process evaluated sites and the "differences allow the Department and Congress to exercise discretionary preferences in choosIng from a wide range of technically acceptable alternatives. It is a matter of fudgment as to which sites are most appropriate for detalled consideraton as candidate MRS sites. The Director exercised his judgment..." (DOE/RW-0023, p. 1)

This paper is to review and critique the process which preceded the Director's judgment among 11 preferred sites, and to try to discern the basis for his final recommendations.

The final siting decision is reserved to Congress.

AN OVERVIEW

DOE's site selection summary (DOE/RW-0023) describes site selection as a four step process (Figure 1). Site screening criterta 'yere established and used to select 11 especially suitable sttes from the universe of acceptable sites. A melange of data of varying relevance was reviewed and all sites were found suitable for safe, effective operation. After comparison on the basis of potential for regulatory or construction delay because of competition with other public objectives, final selection was narrowed to five federally-owned sites. The director exercised his judgment to desig-nate from these a primary and two alternative sites for candidacy. 
Objectives:

- Identify sate sites with minimal adverse environmental impaci

- Enhance mission of integral MAS

- Tinely, cost effective selection

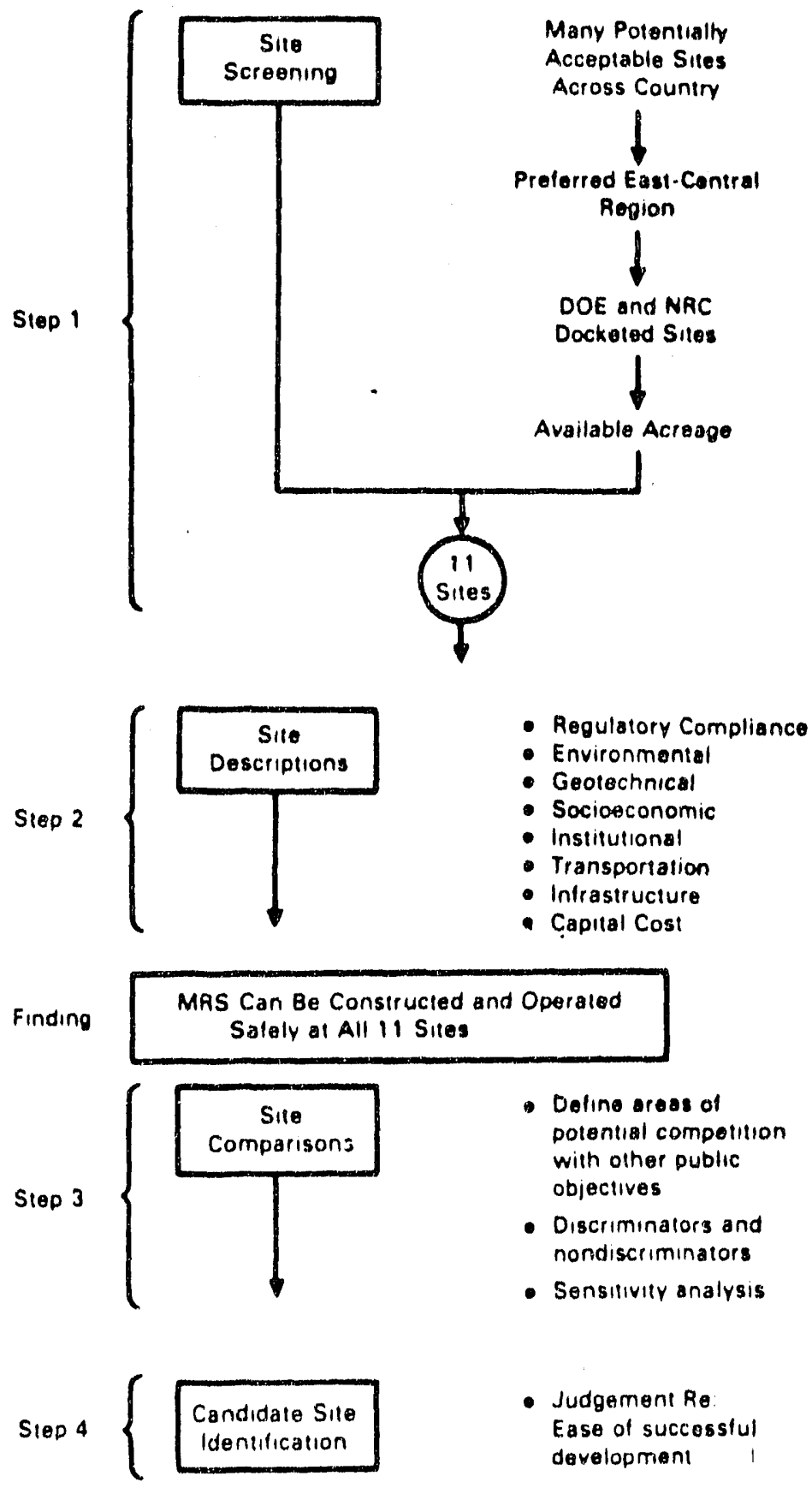

FIGURE 1. PROCESS FOR SITE SCREENING AND IDENTIFICATION OF CANDIDATE MRS SITES (FROM DOE/RW-0023). 
Our reading, in fact, Identifies seven screens through which the designated sites are reported to have passed (Figure 2). It is 1mportant to keep in mind the stated philosophy of the site screening, "factors were 1dentifled which were likely to point out particularly desirable lands rather than to develop exclustonary criterla to screen out undesirable lands... No land was determined tu be unacceptable; rather, the process quickly focused upon sites which were expected to be especially desirable..." (DOE/RW-0023, p. 22.)

The dominant screening factor was the ablitty to judge the suitability of the site for development of a nuclear facility. The ability to judge site suitability depended upon avallability of site data. Two sets of sites have particularly appropriate and avallable data: (1) sites docketed with the Nuclear Regulatory Commision for development of production and utilization facilities (e.g., nuclear reactors), and (2) lands owned by DOE and used for nuclear activities.

MINIMIZING TRANSPORTATION REQUIREMENTS

\footnotetext{
"The primary considerations in identifying a preferred and two alternative sites for an MRS facllity are to locate sites: 1. where an MRS facility can be constructed in a safe, costeffective and timely fashion, with minimal adverse impacts on the local community or environment, and 2. that will enhance the role of an MRS facility as an integral part of the Federal nuclear waste management system. Because the MRS facility is based on engineered containment of the radioactive materials, performance of an MRS factlity would be relatively independent of the specific conditions of the site. In this respect, an MRS facility is quite different from a repository, which is strongly dependent on site conditions for successful performance. Because of this relative independence from specific site conditions, an MRS facllity could be successfully built and operated at any of a large number of sites throughout the U.S." (PNL-542.4, P. 1.4)
}

With site specific characteristics not of critical importance, MRS sitIng studies were confronted with the need to set objectives and to establish some appropriate set of screening criteria for site selection. PNL-5424 argues that if the location of the MRS facility could provide a substantial reduction in total shipment miles for spent fuel and high level waste, then this "could be used as a primary cricerton for discriminating among possible MRS sires" (PNL-5424, p. 3.1). 
I. Preferred Area Based on Minimum Transportation Requirements.

$$
390,000 \text { square miles }
$$

II. Previously Considered for NRC Lilcensing or DOE Owned.

$$
37 \text { sites }
$$

III. Over 1100 Acres.

$$
27 \text { sites }
$$

IV. No Site Use Confilct

$$
11 \text { sites }
$$

V. Site Evaluation
A. Transportation
B. Soctoeconomic
C. Institutional
D. Regulatory
E. Environmental
F. Geotechnical
C. Infrastructure
H. $\operatorname{Cos} t$

From Which the "Discriminators" Are:

1. Potential land use competition

2. Potential competition with environmental regulatory objectives

3. Potential geotechnical site conditions

4. Potential problems with local transportation access

5. Proximity to population centers

$$
9 \text { sites }
$$

VI. Federal Ownership and granting by NRC of limited work authorization or construction permit

VII. Executive Judgment

$$
5 \text { sites }
$$

$$
3 \text { sites }
$$

VIII. Congressional Designation 
The study t) identify a preferred siting region thus took as its stated objective: "to determine

1. the location and shape of a preferred geographic region within which locating an MRS facility would minimize total shipment miles for spent fuel transported through the MRS facility to a repository.

2. The sensitivity of the location and shape of this region and the reduction in total shipment miles to possible varlations in waste management system logistics."

In deciding on this "prinary criterion," shipment miles was chosen to characterize "transportation activities interface with the public" (PNL-5424, p. 3.3). Total shipment miles are notably different from ton miles, which will be increased by the presence of any MRS facility in the system, or from shipment costs. An MRS facility is able to produce a reduction in total shipment miles for 3 reasons: (1) some spent fuel is brought to the MRS facility by truck but is sent on by rall using larger capacity casks; (2) fuel consolidation at the MRS facillty increases the amount of spent fuel that can be placed in a single cask; and (3) with a central stagIng point it is possible to optimize multiple cask rail shipments.

The rationale for minimizing total shipment distance is that shipment costs and risks are ultimately proportional to shipment miles. The potential for ordinary traffic accidents, the costs of security and monttoring, and public anxities are all reduced by minimizing shipment miles. The PNL study showed, however, that "reducing total shipment miles by including an MRS facility in the waste management system does not result in significant changes in transportations costs" and "the risks associated with the transportation operation are small, so the clsk reduction is probably not signiflcant from a public safety standpoint." (PNL-5424, P. A.1)

With no significant impact on transportation costs or public safety, total shipment miles was nonetheless retained as the "primary criterion for discriminating among possible MRS sites." Little further technical justiflcation was offered in PNL-5424. It 18, rather, a matter of public perception and visibllity:

"Reduction of total shipment miles is a logical dominant objective in identifying sultable MRS sites. Transportation of spent fuel and other wastes is a major function of the waste management system which most directly interfaces with the 
public. In commenting on past and current DOE plans and activities, Interested groups and Individuals have repeatedly Identifled transportation as a concern regarding the waste management system." (PNL-5424, p. 1.4)

The PNL 8 tudy thus proceeded in the selection of a regton which would limit total shipment miles to and from the MRS facility to within 20 percent of the lowest achievable. In three basic steps the study (1) permuted all currently considered "systems logistics options," (2) for each permulation of system options, outlined the region which is within 20 percent of the mintmum for total shipment miles and, (3) Identified the common reglon which ts within the 20 percent contour for all options considered. The system loglstics factors which were considered and the range of variability for each are listed in Table 1. A final variable was whether spent fuel from Western reactors would be brought to an Eastern MRS fac1lity.

TABLE 1. RANGES OF WASTE SYSTEM LOGISTICS FACTORS USEDD FOR SITING ANALYSIS*

Factor

Assumed Repository

MRS Lifetime Spent Fuel Throughput

Spent Fuel Rod Consolidation at MRS

Spent Fuel Shipping Cask Capacities

- PWR Truck Cask

- BWR Truck Cask

- PWR Rall Cask

- BWR Ra1l Cask

Ra1l Casks Per Shipment (d)

- from reactors to MRS

- from MRS to repository (e)
Range Used

Nine sites from Hanford, Washington to Richton, Mississippi(a)

$70,000 \mathrm{MTU}$ to $100,000 \mathrm{MTU}(b)$

None $(1: 1)$ to $2: 1(c)$

1 to 2 intact assemblies

2 to 5 intact assemblies

7 to 12 intact assemblies

18 to 32 intact assemblies

(a) Extremes of location for nine sites under consideration for first repository.

(b) Upper limit is all spent fuel projected from existing or planned reactors.

(c) Indicates ratio of spent fuel volune in to volume out.

(d) Truck shipments are limited to one cask per shipment.

(e) All shipments from MRS to repository assumed to be by rall.

* From PNL-5424, p. 5.2. 
A key assumption in the transportation analysis was the location of the spent nuclear fuel. The analysis assumed that the oldest fuel is always brought to the MRS site first so the required data was the locations of the first generated 70,000 - 100,000 MTU of spent fuel. The Energy Information Administration's "No New Orders Case" was used to model where this spent fuel w111 be located.

The process is demonstrated in Figure 3 where the preferred siting region, as defined by three of the possible permutations, ts shown. Table 2 gives the parameter values for the three cases and Figure 3 shows the

TABLE 2. WASTE SYSTEM LOGISTICS FACTORS FOR THREE EXAMPLE CASES

\begin{tabular}{|c|c|c|c|}
\hline Factor & Case A & Case B & Case C \\
\hline Assumed Repository & Hanford, Wash. & Hanford, Wash. & Richton, Miss. \\
\hline $\begin{array}{l}\text { MRS Lifetime Spent Fuel. } \\
\text { Throughput }\end{array}$ & $70,000 \mathrm{MTU}$ & $70,000 \mathrm{MTU}$ & $70,000 \mathrm{MTU}$ \\
\hline $\begin{array}{l}\text { Spent Fuel Rod Consoli- } \\
\text { dation at MRS }\end{array}$ & $1.5: 1$ & $1: 1$ & $1: 1$ \\
\hline \multicolumn{4}{|l|}{$\begin{array}{l}\text { Spent Fuel Shipping Cask } \\
\text { Capac1ties }\end{array}$} \\
\hline - PWR Truck Cask & 1 assemb $1 y$ & 1 assembly & $\begin{array}{l}1 \text { assembly } \\
2 \text { assemblies }\end{array}$ \\
\hline - BWR Truck Cask & 2 assemb.11es & 2 assemb1les & 2 assemblies \\
\hline - PWR Rail Cask & 7 assemblies & $\begin{array}{r}7 \text { assemblles } \\
18 \text { assemblies }\end{array}$ & $\begin{array}{r}7 \text { assemb1les } \\
18 \text { assemb11es }\end{array}$ \\
\hline - BWR Ra11 Cask & 18 assemblies & 18 assemD LLes & \\
\hline \multicolumn{4}{|l|}{ Ra11 Casks Per Shipment } \\
\hline - from reactors to MRS & 1 & 1 & 1 \\
\hline - from MRS to repository & 3 & 1 & 1 \\
\hline
\end{tabular}

+20 percent contours with respect to minfinum total shipment miles for each case, with the area shaded which is within the 20 percent contour for all three cases. The ultimately achieved preferred siting region is shown in Figure 4 and it is clear that the three cases shown provide much of 1 ts definition.

Careful examination of Figure 3 w111 also reveal how much the preferred siting region is constrained by consideration of the Richton, Mississippl repository site, a site which has now been eliminated from consideration for the first repository. In fact, the shipment mile analysis was conducted 


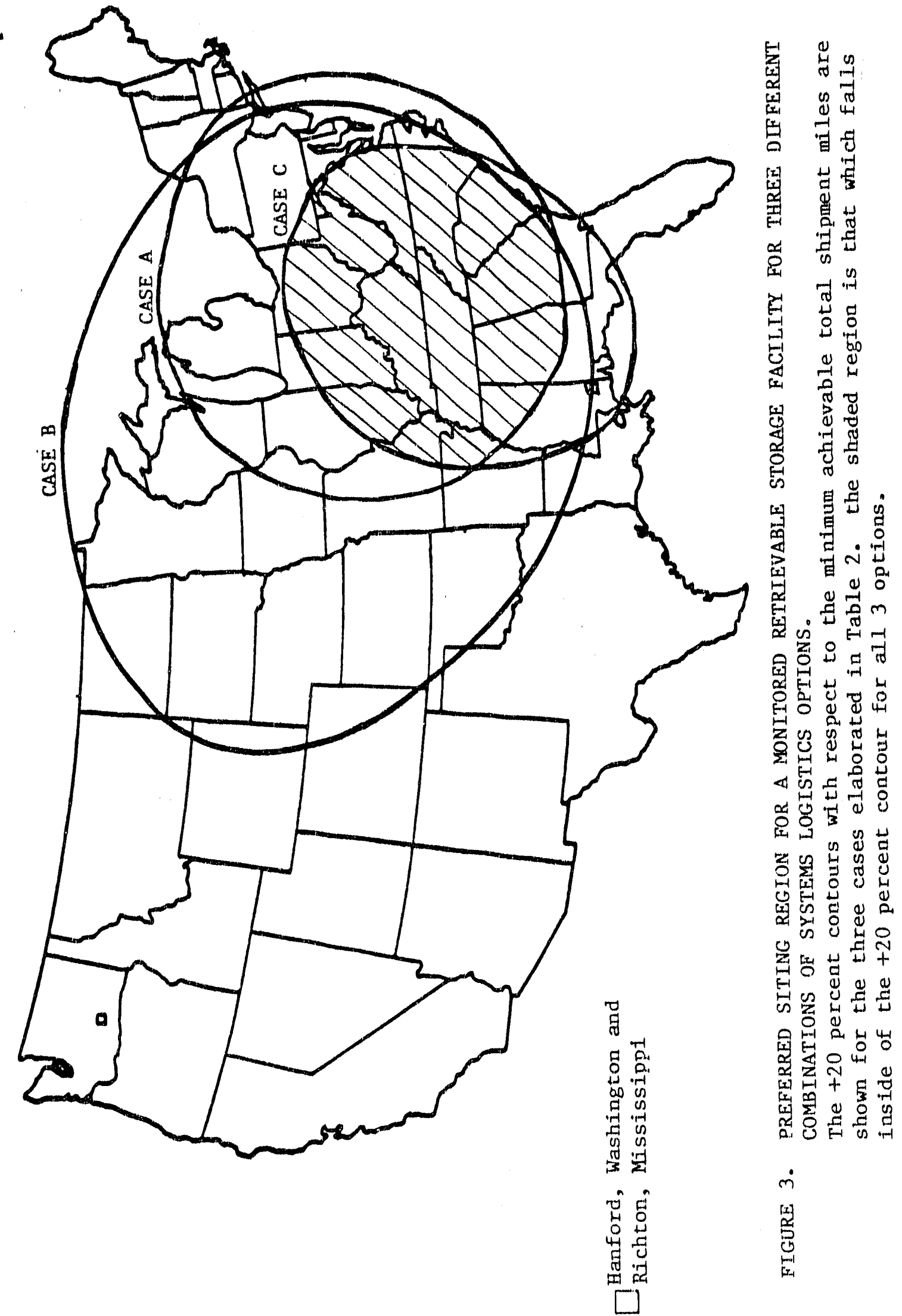




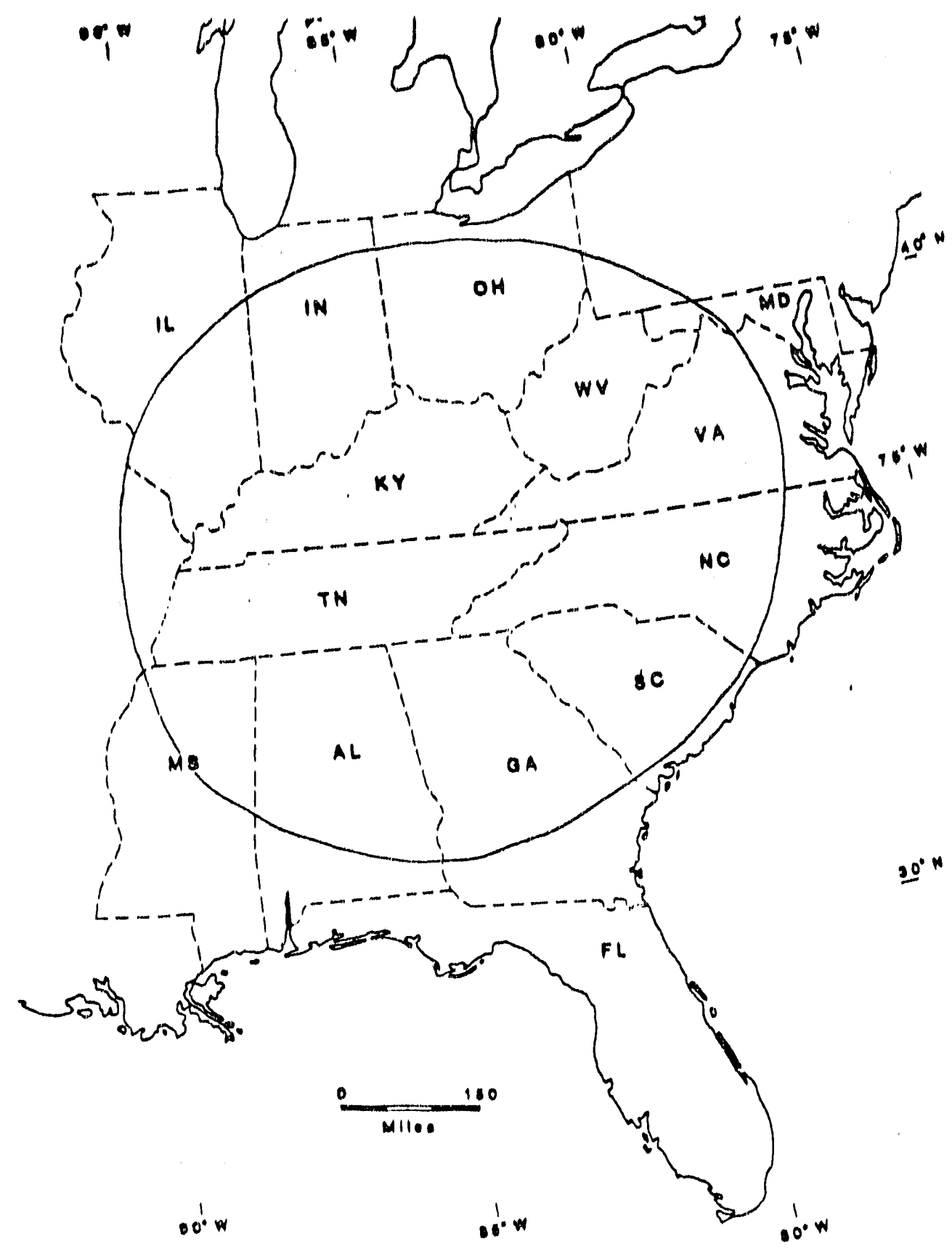

PIGURE 4. PREFERRED SITING REGION FOR A MONITORED RETRIEVABLE STORAGE FACILITY IF TOTAL SHIPMENT MILES ARE WITHIN 20 PERCENT OF THE MINIMUM ACHIEVABLE FOR ANY CURRENTLY CONSTDERED SET OF SYSTEMS LOGISTICS OPTIONS. 
using nine posatble repository attes, only three of whlch are now beling gertously evaluated (as of January 1985). Although the analysts has not been repeated here, it 1 s clear that if only the three extant repository sites were consldered th the lactor premutations, the preferred otting region would be larger and 1ts center would be shifted to the north and west.

To ralse, once agaln, the distinction between total shlpment ditatance and total shipinent cost, the text of PNL-5424 shows minitaun transport cost contours for two sample optlons, both with the reposttory site taken to be at Hanford, Washington. In both cases Hanford ttoelf is within 20 percent of the minimum achlevable transport $\cos t$ and in one of the examples 1 it 18 within 10 percent of the minimurn achlevable. In one example the 20 percent contour encompasseg the ent1re contiguous Untted States.

It to also clear that the PNL transportation study has not consldered al1 of the possibilities. In a research proposal prepared by the spectal. Profects Staff of TVA, other systems Integration options were briefly explored. The T'VA group used a different model of spent fuel generation, a different model for transpurtation mode, and arrlved at quite different conclustons. They did agree that transportation 18 an 1mportant consideration. Using the TVA group's rodel, the centrold for ton-miles for spent fuel. Is in Southwestern Ohlo ( $1 \mathrm{t}$ is in West Virginla in the PNL mode1). However, "the lowest posstble transportation Impact in terms of trip-miles (e.g., shipment. mfles) is for consolidated fuel In a dual-purpose cask shlpped by dedicated train directly to the repository..." That 1s, a system without an MRS. Total shipment miles were clalined to be reduced to 5 percent of those in the DOE MRS Bage Case. If an MRS factilty is to be built,

"The type of transportation system assumed and the extent to which $1 t$ is integrated tinto the overall system have a major effect on the preferred location of an MRS. The optimuin location of an MRS to minimlze trip-miles for the type of transportation systein DOE has assumed, as described above, is in the eastern part of the country tn an area centered around ohlo. The optimum MRS location for a fully integrated system uglng dual-purpose casks shlpped by dedicated train is at the repository site. However, the NWPA forblds siting the MRS in a repository state. Assuinfing the repostitory st.te 18 unknown and the three sttes currently under consideration have equal probability of being selected, the optlmum MRS stte for a fully Integrated trunaportation system would be In the viclntty of Southeastern Colorado near the Oklahoma panhandle." (TVA Speclal Projects Staff, 1985, pp. $42-43.)^{5}$ 
The two locations are both based on equn1. probablifty for the three reposttory oftes at Hanford, Washington; Yuc Flats, Nevada; and Deaf Smith, Texas and the latter location on the further assumption of all shlpments by dedicated tratns.

The preferred steting reglon in Figure 4 was used by DOE as the firat level acreenting factor for Identiflcation and evaluation of potentlal MRS oftes in subsequent studies.

\section{SITE SCREENING}

The Monttored Retrlevable Storage Factlity Site Screening and Evaluation Report (DOE/NBB-007L) was prepared by a tagk force and bears all of the symptoms thereof. It is three volumes long and contalns tables of everything that could be tabulated regardless of its relevance to the isgues at hand. As a consequence of the structure of the study, the report lacks preciston and conviction. The task force conslated of approximately 60 people in six organizations. Work was concentrated into three months. Potential MRS faclitty sites, all in the Eastern United States were evaluated and compared without a site visit and the basts for cost comparisons was Los Angeles Basin data. The report takes 15 chapters to select and evaluate 11 sttes. Transportation, Socloeconomlc, Instltutional, Regulatory, Environmental, Geotechnlcal, Infrastructure, and Cost considerations are discussed and a few ttems ldentifled as discrimlnators for site selection. Dlscrlmitrators are those factors which vary slgniflcantly among the stres and are lmportant fin assessing the potential for MRS factilty development. The seven factors which discriminated anong the sites chosen for evaluation were:

1. exlating federal ownershlp and control;

2. granting by NRC of a limited work authorlzation or construction permit;

3. potential land use competition;

4. potential competition with environmental regulatory objectives;

5. potential geotechnical site conditions;

6. potential problems with local transportation access;

7. proxinity to population centers.

The site screening process began with task force acceptance of the 390,000 square mile area described in Figure 4. The task force was also 
provided by PNL with three screening criteria. The three criterla were:

"Status: Candidate MRS factlity sttes (1) must have been previously considered for licensing by the NRC for construction and operation of a nuclear power plant or fuel reprocessing facllity under 10 CFR 50 or (2) muat be owned and controlled by DOE.

Size: Candidate MRS factlity sites must be of sufflcient slze to allow construction and operation of the facllity.

Site-Use Conflict: No unacceptable or undesirable site-use conflict may exlst at potential MRS faclitty sites" (DOE/NBB-0071, p. 4.1).

Site size requirements are dependent on how much spent fuel is stored and how ti is stored. The base case MRS factlities could store 15,000 tons of spent fuel in storage casks on a 280 acre slte but an alternate scheme would use filetd drywell storage and if a full 70,000 tons were accumulated at an arid MRS site, 1100 acres would be required. Thus, 1100 acres was adopted as the mintmum acceptable site even though it applies to an arid site and the focus is the Southeastern Unted States.

A question about the 1100 acre requirement was ralsed at a July 10 , 1985 MRS Workshop at Tennessee State University. According to the workshop summary prepared by S.W. Haegart of the Tennessee Department of Health and Environment, "The DOE staff pointed out that when the candidate sites were selected, DOE was st111 retalning its option to use the MRS as a backup to a permanent repository. The staff stated that the DOE will seek to limtt the size of the facility to 15,000 MTU in the authoriaing legislation, particularly tf the state requests such a limitation." The fact remains, no site smaller than 1100 acres was considered. Desplte these kinds of Inconsistencles in the physical data, DOE seems committed to the sites selected. At this same workshop, "The DOE staff/contractors agreed that the site selection document was unclear on some of these questions. The document will not be redone, but some of the issues may be investigated further, and addressed In an Appendix to the final need and feasibility document."

Siting adfacent to a licensed nuclear power plant was judged undesirable because, while no combined rlsk was percelved, th might create undesirable 11censing delays. Site use conflict was thus used to reject sites which adjoin or are shared with a licensed nuclear power plant. 
Thirty-seven sites in 12 states were identifled to pass the first of these three screens, 10 were eliminated because they were known to be less than 1100 acres, and another 16 failed to pass the site-use conflict screen, leaving 11 sites for further consideration. The 11 sites are 1 isted in Table 3 and shown on Figure 5.

TABLE 3. CANDIDATE MRS SITES FROM THE INITIAL THREE-STEP SCREENING

\begin{tabular}{|c|c|c|}
\hline State & Site Name & Stte Type \\
\hline Alabama & Barton & Nuclear Power Plant \\
\hline Kentucky & Paducah & DUE Facility \\
\hline Mississ Ippi & Yellow Creek & Nuclear Power Plant \\
\hline North Carolina & Perkins & Nuclear Power Plant \\
\hline South Carolina & $\begin{array}{l}\text { Barnwell } \\
\text { Cherokee } \\
\text { Savannah RIver }\end{array}$ & $\begin{array}{l}\text { Reprocessing Plant } \\
\text { Nuclear Power Plant } \\
\text { DOE Facility }\end{array}$ \\
\hline Tennessee & $\begin{array}{l}\text { Clinch River } \\
\text { Hartsville } \\
\text { Oak Ridge } \\
\text { Phipps Bend }\end{array}$ & $\begin{array}{l}\text { Nuclear Power Plant } \\
\text { Nuclear Power Plant } \\
\text { DOE Facility } \\
\text { Nuclear Power Plant }\end{array}$ \\
\hline
\end{tabular}

Site selection was thus focused on 11 spectfic locations in $s 1 x$ southeastern states. In bluntest terms, selection of these sites was based on public perception (shipment miles) and expediency (site status and site-use conflict), the only physical/technical criteria employed being an ultraconservative allotment of site size. Evaluation of the 11 sites proceeded on a variety of bases, most of whych were ultimately acknowledged to be "nondiscriminators" or inadequately known. Interestingly the tables in Chapter 5 report two of the sites (Yellow Creek and Clinch River) to be under 1100 acres.

Chapters 7 to 14 of DOE/NBB-0071 go through site specific discussions of transportation, socioeconornic, institutional, regulatory, environmental, geotechnical, Infrastructure, and cost considerations respectively. In this text we will try to simply point out the factors considered, note those which were judged useful in discriminating among sites, and call attention to a few site-specific ltems ralsed in regard to the chree alternate sites selected. 


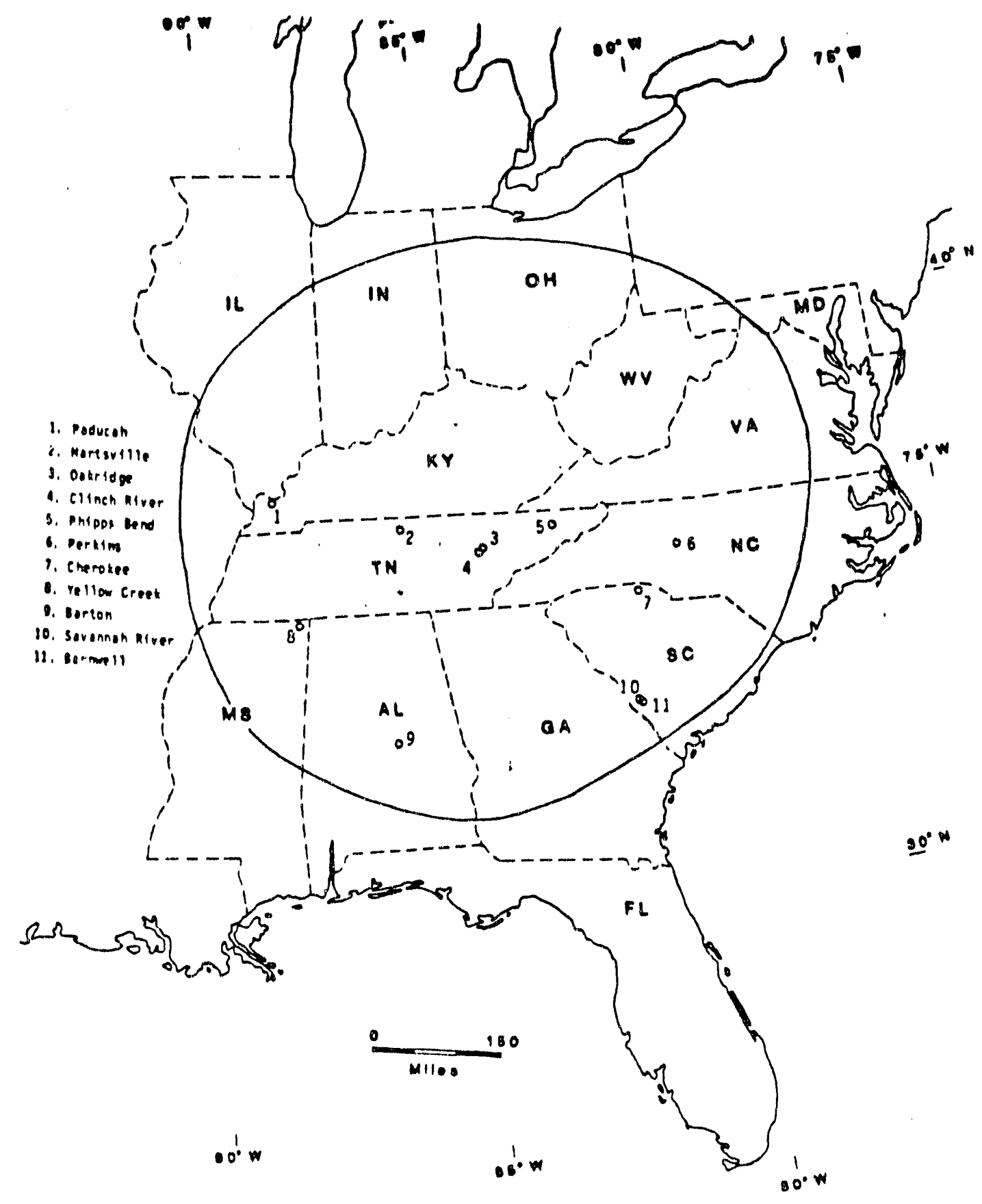

FIGURE 5. CANDIDATE MRS SITES AFTER ANALYZING TOTAL SHIPMENT MILES AND APPLYING A THREE-STEP INITIAL SCREEN ON POTENTIAL SITES. 
The task force's stated intent was to "1dentify and present significant strengths and weaknesses of each site." It is noted that all of the data are based on material avallable in the open literature and that no site visits were made. This lead to some unusual data omissions, such as the concession that for the preferred site, "1t is uncertain who has custody of the land at this time" (DOE/NBB-0071, p. 5.7).

Under Transportational Considerations, "Although it is expected that the necessary transportation capabilitles could be made available at each site, there could be important differences between the sites in the cost of providing these services, in the effects of the transportation operations on the people living in the vicinity of the facility, and in the efficiency of the transportation operations $10 \mathrm{E} / \mathrm{NBB}-0071, \mathrm{p} .7 .1$ ). The elght attributes selected to characterize the transportation considerations are listed in Table 4. Access to barge service was included although there is no current

TABLE 3. ATTRIBUTES SELECTED TO CHARACTERIZE THE TRANSPORTATION CONSIDERATIONS AND SERVE AS A BASIS FOR EXAMINING DIFFERENCES AMONG SITES.

1. Local population density.

2. Number of communities on access route.

3. Distance to main transportation link.

4. Number of large cities on regional transit corridors.

5. Amount of new access required.

6. Special operating conditions (e.g., weather).

7. Number of rall carriers.

8. Access to barge service.

discussion of using barge transport. Although the sites were ranked on the basis of attractiveness, "review of the transportation characteristics for each of the sites Indicated that a safe and reasonably efficlent transportation system could be put in place at all of the sites" (DOE/NBB-0071, p. 7.7). On a relative scale, the Clinch River and Oak Ridge sites were rated "better than average," the Hartsullle site "below average." On the topic of "number of large cities on regional transit corridors," it is 
interesting to note the fraction of reactors whose shipments to the MRS facility would pass through, for example Knoxville and Nashville, if shipped by truck (see Table 5). The point is that so long as the MRS factlity is in

TABLE 5. PERCENT OF REACTORS WHOSE SPENT-FUEL SHIPMENTS WOULD PASS THROUGH KNOXVILLE AND NASHVILLE IF ALL WERE SHIPPED BY TRUCK TO AN MRS SITE

\begin{tabular}{l|c|c}
\hline \multirow{2}{*}{ MRS Site } & \multicolumn{2}{|c}{$\%$ of shipments } \\
\cline { 2 - 3 } & Through Knoxvilie & Through Nashville \\
\hline Barton, Alabama & 23 & 31 \\
Paducah, Kentucky & $<20$ & 25 \\
Yellow Creek, Misslssipp1 & 26 & 49 \\
Perkins, North Carolina & 44 & $<20$ \\
Barnwell, South Carolina & 30 & $<20$ \\
Cherokee, South Carolina & 31 & $<20$ \\
Savannah River, South Carolina & 30 & 31 \\
Clinch River, Tennessee & 47 & 24 \\
Hartsville, Tennessee & 36 & 31 \\
Oak Ridge, Tennessee & 47 & $<20$ \\
Phipps Bend, Tennessee & 60 & \\
\hline
\end{tabular}

the Southeast, a signiflcant fraction of the spent fuel will travel along the regions' principal transport corridors following simflar routes. Socioeconouic considerations focus on "the ability of ench site to absorb the potential soctoeconomic impacts that would accompany the construction and operation of an MRS facility, and estimates the relative increases in demand upon local government resources that may be caused by MRS construction and operation" (DOC/NBB-0071. p. 8.1). A peak work force of 1300 was foreseen. The task force considered the size of the impact relative to the existing base, the current growth trends in the area, and the capacicy of existing communtty resources. Impact projections were based on the PNL Metropolitan and State Economic Regions model. The 1mpact area was defined as all counties lying completely or partially within a 50-mile 
radius of the site* and no attempt was made to evaluate intra-area shifts or stresses. On this basis they projected that all of the areas have large and growing populations and will have to construct new schools regardless of an MRS facility. "Baseline population growth will also require the expansion or construction of hospitals in every area except Yellow Creek" (DOE/NBB$0071, \mathrm{p}$. 8.7). While the study found some difference in the ability of the respective candidate sites, "the primary result of this analysis is that the communtites surrounding each of the eleven sites could easily absorb an MRSrelated soctoeconomic Impact" (DOE/NBB-0071, p. 8.9). Factors evaluated were employment, population, income, schools and hospitals, water, electric and sewer supply, and housing.

"The focus of the effort for the institutional component was to identify characteristics or considerations that could be used to differentiate or discriminate between potential sites. However, ...it was difficult to concelve of any institutional considerations that could serve as absolute discriminators between potentially acceptable sites." Acknowledging further that "we do not know what institutional considerations will be important at any particular site because so much of their context js political and their operation is not triggered until a siting decision is made..." (DOE/NBB0071, p. 9.1), the task force discussion goes on to tabulate the political affiliation of state legislators, the nature of nuclear-related state agencies and legislation, state and local tax structures, the existence of Indian tribes, distance to the state capitol, the ethnic composition of the county population, etc. Institutional considerations were ultimately relegated to the important realm of "secondary discriminators," factors that, other things being equal, might be used to distinguish on the basis of, for example, technical sophistication with respect to nuclear matters.

The chapter on regulatory compliance "examines the characteristics of the candidate MRS factlity sites with respect to the site suitability requirements of $10 \mathrm{CFR}$ part 72 , and other legally-imposed requirements. At this stage of siting, it is not possible to project regulatory compliance. Theiefore, this section provides only indicators of relative ease of achieving

\footnotetext{
*For the Clinch River and Oak Ridge sites this means that Anderson, Knox, Loudon and Roane counties were considered to be the impact area. For Hartsville, the Impact area was considered to be Macon, Sulth, Trousdale, and Wilson counties. Declining school enrollment in Oak Ridge, for example, does not show in overal growth of the four county area.
} 
regulatory compllance at each potential site. These Indicators are 'conditions' which may need to be investigated in order to ultimately judge whether a facility located at a site can achieve regulatory compllance" (DOE/NBB-0071, p. 10.1).

The significant attributes, based on 10 CFR 72, and other applicable leglslation, are listed in Table 6.

TABLE 6. FACTORS THAT MIGHT DISCRIMINATE AMONG SITES ON THE BASIS OF EASE OF REGULATORY COMPLIANCE

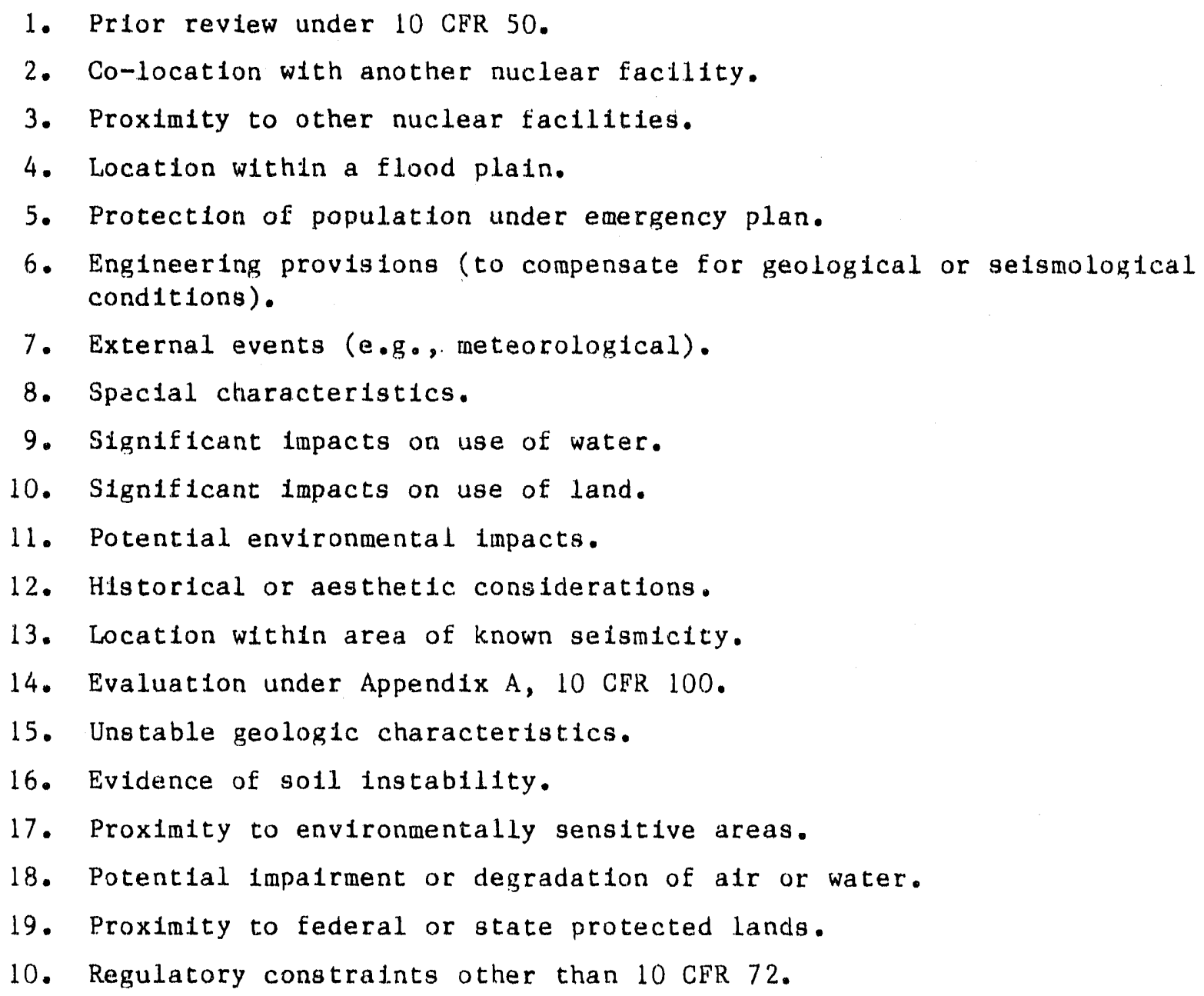

An overlapping of factor classifications is seen in the site evaluation of environmental considerations. The ten attributes considered (Table 7) overlap conslderably with those already raised. Aesthetics ts highly concerned with site visibility, that is, how many people will see the facility. "The least number of people who would see the project area is considered a desirable attribute" (DOE/NBB-0071, P. 11-14). Th1s is an interesting 
TABLE 7. ENVIRONMENTAL AT'TRIBUTES CONSIDERED

AS POSSIBLE SITE DISCRIMNATORS

\author{
1. Aesthetics \\ 2. Alr Quality \\ 3. Cultural Resources \\ 4. Ecology \\ 5. Health and Safety \\ 6. Land Use \\ 7. Meteorology \\ 8. Nolse and Vibration \\ 9. Transportation \\ 10. Water Quality
}

contrast to the Clinch RIver Task Force ${ }^{6}$ request for a visitor center ( $1 \mathrm{f}$ elther Oak Ridge site is chosen) so that the plant would not appear mysterlous or dangerous.

Geotechnical constderatons "were based on the judgment concerning which technical 1ssues are most $11 \mathrm{kely}$ to affect:

- the performance of englneered systems;

- the requirements for successful and timely regulatory approval;

- the feaslbility and economy of site development."

The cursory level of inquiry and the overriding bellef that an MRS facility could be englneered for almost any site 18 reflected in the task force statement that "The 1ist of geotechnical considerations does not include all possible geotechnical factors, but is considered to be appropriate for the current scale of study, the level of avallable data, and the purpose of identifying Important distinctions among various potential sites" (DOE/NBB0071 , p. 12.1).

The most important characteristics were considered to be those related to geology/selsmology, ground water, surface water, and foundation and construction considerations. Many of the factors considered did not meaningfully distinguish among sites at the level Investigated. For example, a1 three of the Tennessee sites selected were clted for the same defictences: the possibility of solution cavities, inadequate depth to the saturated 
zone, the necessity of extensive rock excavation, and surface materials of questionable bearling strength to support the Recelving and Handling butldings. Al1 of these are amenable to englneered solutions but ultimately affect profect cost. In the suminary tables, all three sites were shown to be subfect to moderate cost impact due to these four factors, but the factors were not percelved to have an important impact on 11censing, the environment, or scheduling.

"Infrastructure consists of elements that are required to the the MRS facility 1nto the local environment" ( $p .13 .1$ ). The attributes that were considered as potential discriminators in this area were utilities, transportation (again), labor, and supplies (fuel oll). With no attempt to contact local authortties for information, some of the possible criteria were laid aside for lack of information. While the conclusion was that "none of the infrastructure attributes are a constraint at any of the sites" (DOE/NBB-0071, p. 13.4), Indications were that all 11 sites would require onsite sewage treatment systems.

Finally, the site screening study dealt with costs. Not absolute costs or all costs, but relative costs, and those costs which might be significantly different at the different sites. Costs of land, right-of-way and easements, were not included. Socloeconomic, geotechnical, environmental, and Infrastructure considerations were Included as were existing site conditions. Los Angeles Basin costs were used as a basis and then translated to the varlous local conditions with an adjustment factor which compensated for differences in labor rates, material costs, frelght and productivity. For the geotechnical considerations flagged, costs were included to permit. detalled studies and to develop deslgn criterta but not to engineer solutions that might be required. Normalized costs of an MRS facility at each of the 11 sites are compared in Table 8.

The site screening study did not of fer a suggestion among the 11 sites evaluated. It concluded with the recommendation "that DOE, prior to 1dent1fication of a preferred and two alternative candidate sttes for the MRS factlity, confirm, to the extent posstble, the condition and status of the st.te, as well as the applicable federal, state, arid local agencles to conf1rm general conclusions and data base conditions" (DOE/NBB-0071, P. 15-16). 


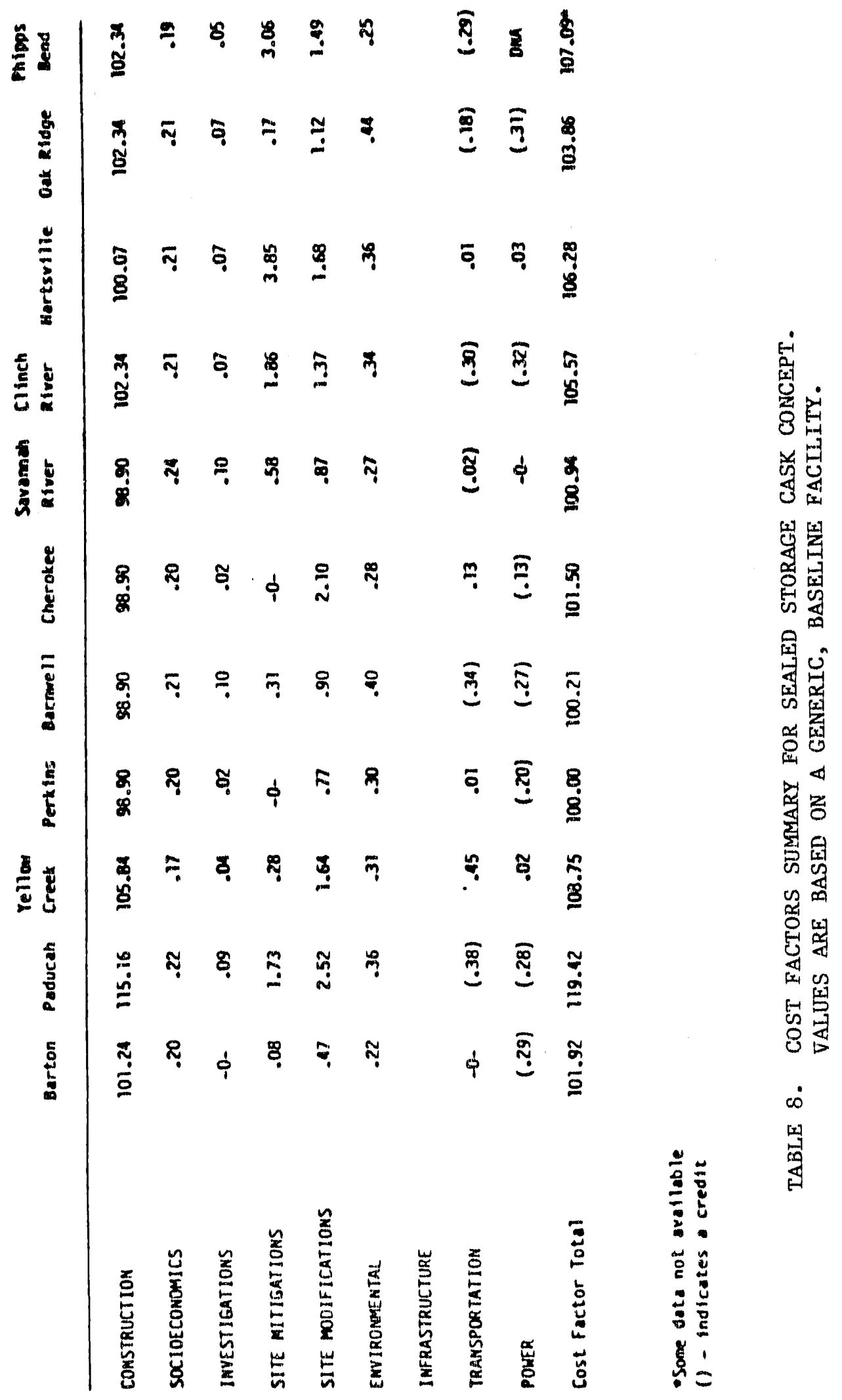


The avaluations were sumnarized in 11 Tables (see Appendix). There to no obvious quantative relationshlp between these tables and the three stesm ultimately chosen, suggeating that Indeed the mafortty of the ste screantng data did not elgure importantiy in the atte selection process. In fact, th the executive summary, four of the elght types of conglderations were dismigsed as unimportant (see Table 9), leaving only regulatory, environmental, geotechntcal and cost tssues for ditacriatnation anong sttes. In cloatng comments, the task force also underltned the advantage of DoE-owned sites:

"DOE-owned sttes may offer several schedule, infrastructure and cost advantages over privately-owned sites. These advantages are related to site access, site acquisttion, securtty provislons, and emergency preparodness and response. Those advantages have not risen to the level of the evaluations of the task force. It ts recommended that the potential advantages be accounted for prior to final ofting decisions" (DOE/NBB-0071, p. 1.10).

\section{SIT'E SELECTION}

As a final step, the question was posed, Which of the data avallable truly discrininate anong the sites with respect to ease and likelihood of success of deploylng an MRS facllity? This was seen not In terins of technical suttablifty or safety, but tn terms of potential delay or disapproval as a result of conflict with public prlorities or exlsting regulations. Congressional authorlzation, NRC licensing, and EPA perintth are the three steps where such obstacles would be encountered. Table 1011 st:s the areas of potential competition with existing public prtortites. On this basts, the Yellow Creek and Paducah sites were eliminated from further consideration. Yellow Creek because of proximity to the recreation area at Plckwlck Lake, and Paducah because ti is in non-attalnment of national alr quality standards and because $1 t$ to in an area designated by EPA for preventing further detertoration of atr quality. In both cases problems were not anticlpated but 11censing delays were seen as more likely than for the other sites.

of the remalning nine sttes, flve are under federal ownership and flnal selection was made from anong the Clinch River, Hartsville, Oak Ridge, Phipps Bend, and Savannah Rlver sltes. "The advantages of current federal ownersh1p" (DOE/RW-0023, p. 2) were ctted as, "Federal ownership reduces 
TABLE 9. NONDISCRIMINATING CONSTDERATIONS

(FROM DOE/NBB-0071 EXECU'TIVE SUMMARY)

Transportation Conslderations

"Tranaportacion conslderationa Identifted differences between attes. However, the ditferences are, in the fudgment of tha task force, relatively minor."

Soctooconomtc Constderations

"While the socioeconomic impacts varted from site to site, no potential Lmpacts were tdentffied which would exclude any gite from consideration as a candidate MRS factilty site. The soctoeconomic 1mpacta at each st te are, In general, profected to be small."

Institutional Constderations

"...few slgniflcant differences were ldentifled between sitee which are relevant to MRS siting declolons."

Infrastructure Constderations

"Infrastructure conslderations revealed differences between sltes. However, these diffrences were not found to be slgnificant in terus of discriminating sttes."

TABLE 10. SITE DISCRIMINATING FACTORS IN TERMS OF POTENTIAL CONF'LICT WITH EXISTING PUBLIC PRIORITLES

1. Land-use competition or proxintty to apectal areas.

2. Competition with environmental regulatory objectives.

3. Geotechnical site conditions.

4. Local transportation access.

5. Proxinity to population centers. 
potential. For conflict regarding toe of the otte and assuras accesg for additonal Lnvestigations" (DOL/RW-0023, p. 2). It aloo does not needlessly ramove land from the pelvate domatin.

As described earlier, this inal selectlon was based on the fudgment of the DLrector of the DOe Offlce of Clviltan Radloactive Waste Management and his advisors. Although at this polnt there was a 40 percent chance that random selection would place all three sittes in tenessee, thera was apparently a corisclous dectsion to do so.

The only statementg directly confronting the selection of three sites In a elingle state ares

"The Departinent will asoure that the State of Tennessee has adequate opportunity to understand the technlcal and nontechnical effects of MRS development. In that the three stes are all in a alngle state, this can be accomplished without diverting attention to lnterstate procedural or programatic parity. The dectgton to Identify sites within a single gtate cane only after determination that none of the other federal sttes carried with them charactertstica (techntcal, envtronmental or land use) which made them superior to the three sites Identifled." (DOE/RW-0023, p. 2)

In elaborating "several partlcularly destrable features" in support of the Clinch River selection, DOE cited three which are loglcal outgrowths of the site screening process plus a fourth which lo a new polnt, "4) technical. communtey in the vicintty of site which can provide expertenced nuclear support functions." (DOE/RW- 0023, p. 2)

\section{CONCLUSION}

Our conclusion ts that the technical basis for selection of Oak Ridge to host an MRS faclitty is very weak Indeed. There is no convincing argument that the site offers advantages in the way of trangportation risk or cost. Selection of a preferred siting regton was based on some outdated Information and a "system" for spent fuel processing and disposal which 1.8 st111 poorly deflned and subfect to many 1mportant varlables. Screening on the basts of 1100 avallable acres was unnecessartly conservative and the site evaluation process found all 11 nominated sites to be acceptable on the bas1s of enviroumental, geotechntcal, soctoeconomlc, etc., factors. The subjectlve judgment of the Director formed the acknowledged basis for final. 
selection. If we accept the arguments of the glte screenling and evaluation tagk force, there are a near Infinite number of U.S. attes that could be englneered to host the MRS faclilty without algniflcant change in public rlak or cost.

This lo not to argue that the final cholces were not good cholces, but almply to make the polnt that the detalled atte selection documentation falls to make convincing argument that there is any techntcal reason for the cholces. The three Tennessee sites are netther unique nor technically easentlal to the success of the spent fuel handilng system. We note, however, that a sense of expedtency, of acceptablifty, played an Important, and undoubtedly valid, role in site gelection. The political, tnfrastructure, conslderations are raal and seem to have played a more lmportant role than one would necessarly percelve in the bulk of the stte screenting evaluations. Because of tts "exlating proxlmlty to nuclear Infrastructure" Tennessee, and Oak Ridge in particular, provide a relatively hospltable climate for what will Inevttably be a controversial project. If the stte screenting and evaluation process falls to make a compeliting technical argument in favor of Oak Ridge, tit does show that, at a ursory level, other possible chotces are not. demonstrably preferable. If Oak Ridge 18 at least as good as other poss1bliftes, and casts an lmage such that local and state acceptance appear 11kely, then, Why not Dak Ridge? Th1s 1s, In fact, In keeping with the stated philosophy of the stte screenlng.

"Factors were ldentifled which were likely to polnt out particularly destrable lands rather than to develop excluatonary criterta to screen out undestrable lands. In employing thits approach, large amounts of land were eliminated from consideration even though acceptable sttes could be found among such lands. No land was determined to be unacceptable; rather, the process quickly focused upon sties which were expected to be espectally destrable and for which detalled Information was avallable" (DOE/RW-0023, p. 22.)

Our feeling lo that there are many reasons for select.lng Oak Ridge, none of which have very much to do with the geographic, physlcal, or economic attributes of the stte. This feeling is supported by an october 21 meeting at which Oak Ridge Clty Counc1l expressed that $1 \mathrm{t}$ "would willingly accept" the MRS facility, glven a liat of speciflc conditions. 
Regulatory compltance and confltct whth other publlc prtortties are clearly stated screenting criterta, and DOE's perception of how these will come into play has had a mafor role th the stte selection. Political expediency ts not necesarily a poor basts for selection if the factilty ts truly benign and has no site-speciflc tmpacts or requirements.

Oak Ridge, and Tennessee, thus have the option of accepting the MRS faclitty whlle acknowledging that there ls little persuasive technical argumentation in favor of selecting thlo preferred site. Or, they can easily oppose the site by arguing, "Why Tennessee?" 
REFERENCES

1. 97th Congress, 1983, Public Law 97-425, Nuclear Waste Policy Act of 1982 , January $7,1983$.

2. Holter, G.M. and J.L. Braltman. 1985. Siting of an MRS Facility: Identification of a Geographic Region that Reduces Transportation Requirements, Pacific Northwest Laboratory, PNL-5424, Apri1.

3. Golder Assoclates, Inc. 1985. Monftored Retrievable Storage Fac1lity Site Screenting and Evaluation Report, prepared for U.S. Department of Energy, Rtchlands Operation, DOE/NBB--0071, 3 volumes, May.

4. U.S. Department of Energy, Office of Civilian Radioactive Waste Management. 1985. Screening and Identification of Sites for a Proposed Monitored Retrlevable Storage Fac1lity, DOE/RW-0023, April.

5. Tennessee Valley Authority Spectal Profects Staff. 1985. Proposal to perform a comprehensive integrated systems evaluation of alternatives for centralized (MRS) and decentralized (reactor) spent nuclear fuel management systems pursuant to geologlc disposal. Draft, June 25, 1985.

6. Clinch RIver MRS Task Force. 1985. Recommendations on the Proposed Monitored Retrievable Storage Facility, Roane County, City of Oak Ridge, Oak Ridge, Tennessee, October. 
APPENDIX

SUMMARY OF EVALUATION FOR

11 CANDIDATE SITES FOR AN MRS FACILITY 


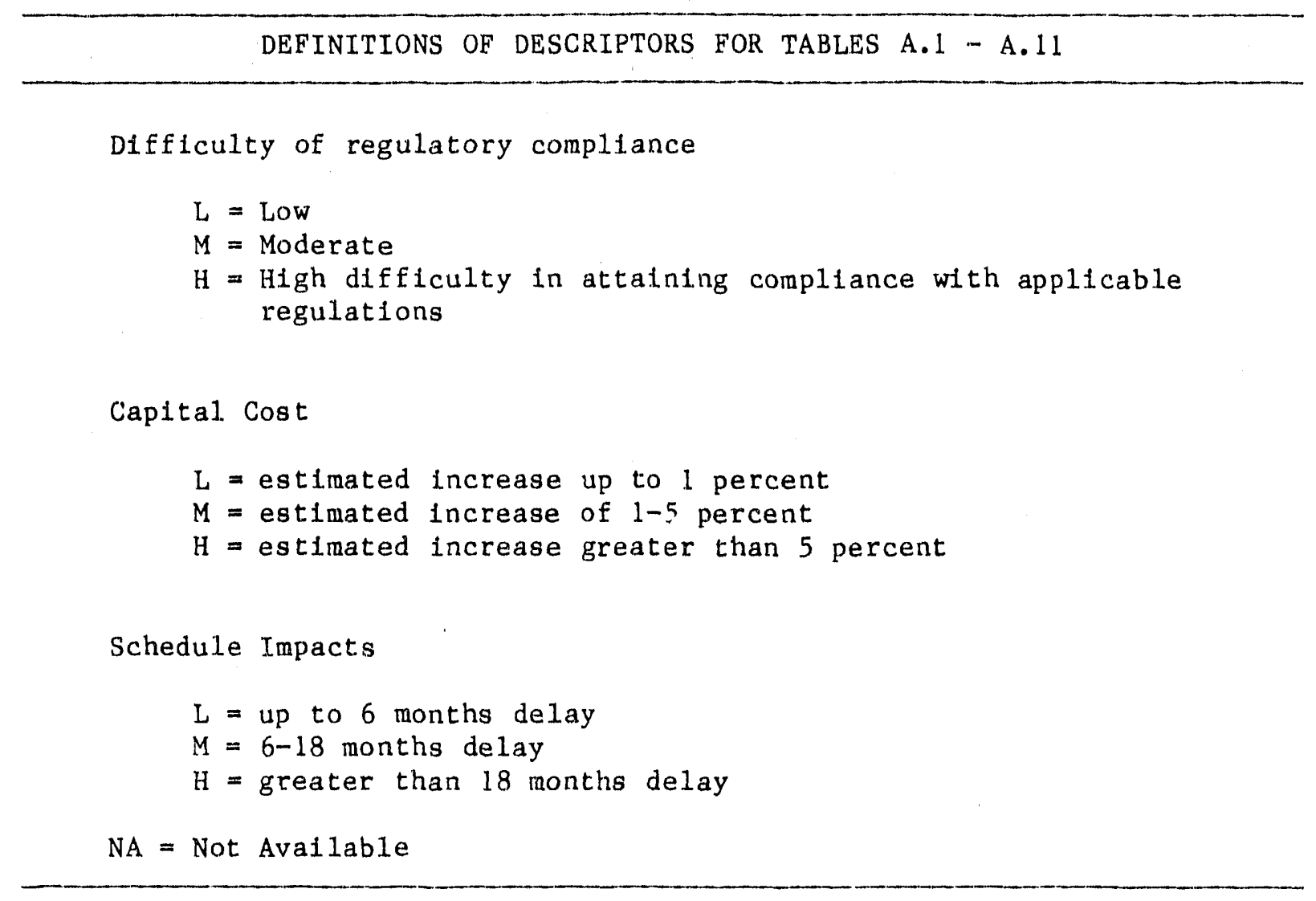


TABLE A.1. SUMMARY OF EVALUATIONS FOR BARTON, ALABAMA SITE OWNERSHIP: ALABAMA POWER COMPANY,

\begin{tabular}{|c|c|c|c|}
\hline & $\begin{array}{l}\text { Difficulty in } \\
\text { Regulatory } \\
\text { Compliance } \\
\end{array}$ & $\begin{array}{l}\text { Capital } \\
\text { Cost } \\
\text { Impacts } \\
\end{array}$ & $\begin{array}{l}\text { Schedule } \\
\text { Impacts }\end{array}$ \\
\hline Transportation & $\mathrm{L}$ & $\mathrm{L}$ & $\mathrm{L}$ \\
\hline Socloeconomics & $\mathrm{N} / \mathrm{A}$ & $\mathrm{L}$ & $\mathrm{L}$ \\
\hline Institutional & $\mathrm{L}$ & $\mathrm{L}$ & $\mathrm{L}$ \\
\hline Environmental & $\mathrm{L}$ & $\mathrm{L}$ & $\mathrm{L}$ \\
\hline Geotechnica1 & $\mathrm{L}$ & $\mathrm{L}$ & $\mathrm{L}$ \\
\hline Infrastructure & $\mathrm{L}$ & $\mathrm{L}$ & L \\
\hline Site Development & $\mathrm{L}$ & M & $\mathrm{L}$ \\
\hline
\end{tabular}

TABLE A.2. SUMMARY OF EVALUATIONS FOR PADUCAH, KENTUCKY SITE OWNERSHIP: DEPARTMENT OF ENERGY

\begin{tabular}{|c|c|c|c|}
\hline & $\begin{array}{l}\text { Difficulty in } \\
\text { Regulatory } \\
\text { Compliance } \\
\end{array}$ & $\begin{array}{l}\text { Capital } \\
\text { Cost } \\
\text { Impacts } \\
\end{array}$ & $\begin{array}{l}\text { Schedule } \\
\text { Impacts }\end{array}$ \\
\hline Transportation & $\mathrm{L}$ & $\mathrm{L}$ & $\mathrm{L}$ \\
\hline Socioeconomics & $\mathrm{N} / \mathrm{A}$ & $\mathrm{L}$ & $L$ \\
\hline Institutional & L & L & L. \\
\hline Envi ronmental & $\mathrm{H}$ & $\mathrm{L}$ & H \\
\hline Geotechnical & $\mathrm{H}$ & $\mathrm{H}$ & H \\
\hline Infrastructure & $\mathrm{L}$ & $\mathrm{L}$ & $M$ \\
\hline Site Development & $\mathrm{L}$ & $\mathrm{L}$ & L \\
\hline
\end{tabular}


TABLE A.3. SUMMARY OF EVALUATIONS FOR YELLOW CREEK, MISSISSIPPI SITE OWNERSHIP: TENNESSEE VALLEY AUTHORITY

\begin{tabular}{lcccc} 
& $\begin{array}{l}\text { Difficulty in } \\
\text { Regulatory } \\
\text { Compliance }\end{array}$ & & $\begin{array}{l}\text { Capital } \\
\text { Cost } \\
\text { Impacts }\end{array}$ & $\begin{array}{l}\text { Schedule } \\
\text { Impacts }\end{array}$ \\
Transportation & L & & & \\
Socioeconomics & N/A & L & L \\
Institutional & L & L & L \\
Environmental & M & L & H \\
Geotechnical & L & L & M \\
Infrastructure & L & M & L \\
Site Development & L & L & L \\
\hline
\end{tabular}

TABLE A.4. SUMMARY OF EVALUATIONS FOR PERKINS, NORTH CAROI.INA SITE OWNERSHIP: DUKE POWER COMPANY

\begin{tabular}{lccc}
\hline & $\begin{array}{l}\text { Difficulty in } \\
\text { Regulatory } \\
\text { Compliance }\end{array}$ & $\begin{array}{l}\text { Capital } \\
\text { Cost } \\
\text { Impacts }\end{array}$ & $\begin{array}{l}\text { Schedule } \\
\text { Impacts }\end{array}$ \\
Transportation & L & L & L \\
Socioeconomics & N/A & L & L \\
Institutional & L & L & L \\
Environmental & M & L & L \\
Geotechnical & L & L & L \\
Infrastructure & L & L & L \\
Site Development & L & L & M \\
\hline
\end{tabular}


TABLE A.5. SUMMARY OF EVALUATIONS FOR BARNWELL, SOUTH CAROLINA SITE OWNERSHIP: ALLIED CHEMICAL

\begin{tabular}{|c|c|c|c|}
\hline & $\begin{array}{l}\text { Difficulty in } \\
\text { Regulatory } \\
\text { Compliance } \\
\end{array}$ & $\begin{array}{l}\text { Capttal } \\
\text { Cost } \\
\text { Impacts } \\
\end{array}$ & $\begin{array}{l}\text { Schedule } \\
\text { Impacts }\end{array}$ \\
\hline Transportation & $\mathrm{L}$. & L & $\mathrm{L}$ \\
\hline Soctoeconomics & $\mathrm{N} / \mathrm{A}$ & $\mathrm{L}$ & $L$ \\
\hline Institutional & $\mathrm{L}$ & $\mathrm{L}$ & $\mathrm{L}$ \\
\hline Env1ronmental & L & L & $\mathrm{L}$ \\
\hline Geotechnical & $M$ & $M$ & $M$ \\
\hline Infrastructure & $\mathrm{L}$ & $\mathrm{L}$ & $\mathrm{L}$ \\
\hline Site Development & $\mathrm{L}$ & $\mathrm{L}$ & $\mathrm{L}$ \\
\hline
\end{tabular}

TABLE A.6. SUMMARY OF EVALUATIONS FOR CHERUKEE, SOUTH CAROLINA SITE OWNERSHIP: DUKE POWER COMPANY

\begin{tabular}{lcccc}
\hline & $\begin{array}{l}\text { Difficulty in } \\
\text { Regulatory } \\
\text { Compliance }\end{array}$ & & $\begin{array}{l}\text { Capital } \\
\text { Cost } \\
\text { Impacts }\end{array}$ & $\begin{array}{l}\text { Schedule } \\
\text { Impacts }\end{array}$ \\
\cline { 2 - 3 } Transportation & L & & \\
Soctoeconomics & N/A & L & L \\
Institutional & L & L & L \\
Environmental & M & L & L \\
Geotechnical & L & L & M \\
Infrastructure & L & L & L \\
Site Development & L & L & L \\
\hline
\end{tabular}


TABLE A.7. SUMMARY OF EVALUATIONS FOR SAVANNAH RIVER, SOUTH CAROLINA SITE OWNERSHIP: DEPARTMENT OF ENERGY

\begin{tabular}{|c|c|c|c|}
\hline & $\begin{array}{l}\text { Difficulty in } \\
\text { Regulatory } \\
\text { Compliance } \\
\end{array}$ & $\begin{array}{l}\text { Capital } \\
\text { Cost } \\
\text { Impacts } \\
\end{array}$ & $\begin{array}{l}\text { Schedule } \\
\text { Impacts }\end{array}$ \\
\hline Transportation & $\mathrm{L}$ & $\mathrm{L}$ & $\mathrm{L}$ \\
\hline Socloeconomics & $\mathrm{N} / \mathrm{A}$ & $\mathrm{L}$ & $\mathrm{L}$ \\
\hline Institutional & $\mathrm{L}$ & $\mathrm{L}$ & $\mathrm{L}$ \\
\hline Environmental & $\mathrm{L}$ & L & L \\
\hline Geotechntcal & $M$ & M & M \\
\hline Infrastructure & $\mathrm{L}$ & $\mathrm{L}$ & $\mathrm{L}$ \\
\hline S1te Development & $L$ & $\mathrm{~L}$ & $\mathrm{~L}$ \\
\hline
\end{tabular}

TABLE A.8. SUMMARY OF EVALUATIONS FOR CLINCH RIVER, TENNESSEE SITE OWNERSHIP: U.S. GOVERNMENT (TVA CUSTODY)

\begin{tabular}{lccc}
\hline & $\begin{array}{l}\text { Difficulty in } \\
\text { Regulatory } \\
\text { Compliance }\end{array}$ & $\begin{array}{l}\text { Capital } \\
\text { Cost } \\
\text { Impacts }\end{array}$ & $\begin{array}{l}\text { Schedule } \\
\text { Impacts }\end{array}$ \\
Transportation & $\mathrm{L}$ & $\mathrm{L}$ & $\mathrm{L}$ \\
Socioeconomics & $\mathrm{N} / \mathrm{A}$ & $\mathrm{L}$ & $\mathrm{L}$ \\
Institutional & $\mathrm{L}$ & $\mathrm{L}$ & $\mathrm{L}$ \\
Environmental & $\mathrm{M}^{(\mathrm{a})}$ & $\mathrm{L}$ & $\mathrm{M}(\mathrm{a})$ \\
Geotechnical & $\mathrm{L}$ & $\mathrm{M}$ & $\mathrm{M}$ \\
Infrastructure & $\mathrm{L}$ & $\mathrm{L}$ & $\mathrm{L}$ \\
Site Development & $\mathrm{M}$ & $\mathrm{M}$ & $\mathrm{M}$ \\
\hline
\end{tabular}

(a) State has applied for attalment status for ozone. If EPA does not grant this request the difficulty for regulatory compliance will. increase. 
TABLE A.9. SUMMARY OF EVALUATIONS FOR HARTSVILLE, TENNESSEE SITE OWNERSHIP: TENNESSEE VALLEY AUTHORITY

\begin{tabular}{|c|c|c|c|}
\hline & $\begin{array}{l}\text { Difficulty in } \\
\text { Regulatory } \\
\text { Compliance } \\
\end{array}$ & $\begin{array}{l}\text { Capital } \\
\text { Cost } \\
\text { Impacts } \\
\end{array}$ & $\begin{array}{l}\text { Schedule } \\
\text { Impacts }\end{array}$ \\
\hline Transportation & L & $\mathrm{L}$ & $\mathrm{L}$ \\
\hline Soctoeconomics & $\mathrm{N} / \mathrm{A}$ & L & L \\
\hline Institutional & ᄂ & $\mathrm{L}$ & $\mathrm{L}$ \\
\hline Environmental & M & $\mathrm{L}$ & M \\
\hline Geotechnical & $\mathrm{L}$ & $\mathrm{H}$ & M \\
\hline Infrastructure & $\mathrm{L}$ & L & $\mathrm{L}$ \\
\hline Site Development & L & $\mathrm{H}$ & M \\
\hline
\end{tabular}

TABLE A.10. SUMMARY OF EVAYUATIONS FOR OAK RIDGE, TENNESSEE SITE OWNERSHIP: DEPARTMENT OF ENERGY

\begin{tabular}{lcccc}
\hline & $\begin{array}{l}\text { Difficulty in } \\
\text { Regulatory } \\
\text { Compliance }\end{array}$ & & $\begin{array}{l}\text { Capital } \\
\text { Cost } \\
\text { Impacts }\end{array}$ & $\begin{array}{l}\text { Schedile } \\
\text { Impacts }\end{array}$ \\
\cline { 2 - 3 } Transportation & $\mathrm{L}$ & & \\
Socioeconomics & $\mathrm{N} / \mathrm{A}$ & $\mathrm{L}$ & $\mathrm{L}$ \\
Institutional & $\mathrm{L}$ & $\mathrm{L}$ & $\mathrm{L}$ \\
Environmental & $\mathrm{M}(\mathrm{a})$ & $\mathrm{L}$ & $\mathrm{L}$ \\
Geotechnical & $\mathrm{L}$ & $\mathrm{L}$ & $\mathrm{M}(\mathrm{a})$ \\
Infrastructure & $\mathrm{L}$ & $\mathrm{M}$ & $\mathrm{M}$ \\
Site Development & $\mathrm{L}$ & $\mathrm{L}$ & $\mathrm{L}$ \\
\hline
\end{tabular}

(a) State has applied for attalment status for ozone. If EPA does not grant this request the difficulty for regulatory compliance will increase. 
TABLE A.11. SUMMARY OF EVALUATIONS FOR PHIPPS BEND, TENNESSEE SITE OWNERSHIP: TENNESSEE VALLEY AUTHORITY

\begin{tabular}{|c|c|c|c|}
\hline & $\begin{array}{l}\text { Difficulty in } \\
\text { Regulatory } \\
\text { Compldance }\end{array}$ & $\begin{array}{l}\text { Capltal } \\
\text { Cost } \\
\text { Impacts } \\
\end{array}$ & $\begin{array}{l}\text { Schedule } \\
\text { Impacts }\end{array}$ \\
\hline Transportation & $\mathrm{L}$ & $\mathrm{L}$ & $L$ \\
\hline Soctoeconomics & $\mathrm{N} / \mathrm{A}$ & $\mathrm{L}$ & $\mathrm{L}$ \\
\hline Institutional & L & $L$ & $L$ \\
\hline Envit ronmental & M & $\mathrm{L}$ & M \\
\hline Geotechnica1 & $\mathrm{L}$ & M & $M$ \\
\hline Infrastructure & L & $\mathrm{L}$ & $\mathrm{I}_{4}$ \\
\hline Site Development & M & $\mathrm{H}$ & $\mathrm{H}$ \\
\hline
\end{tabular}



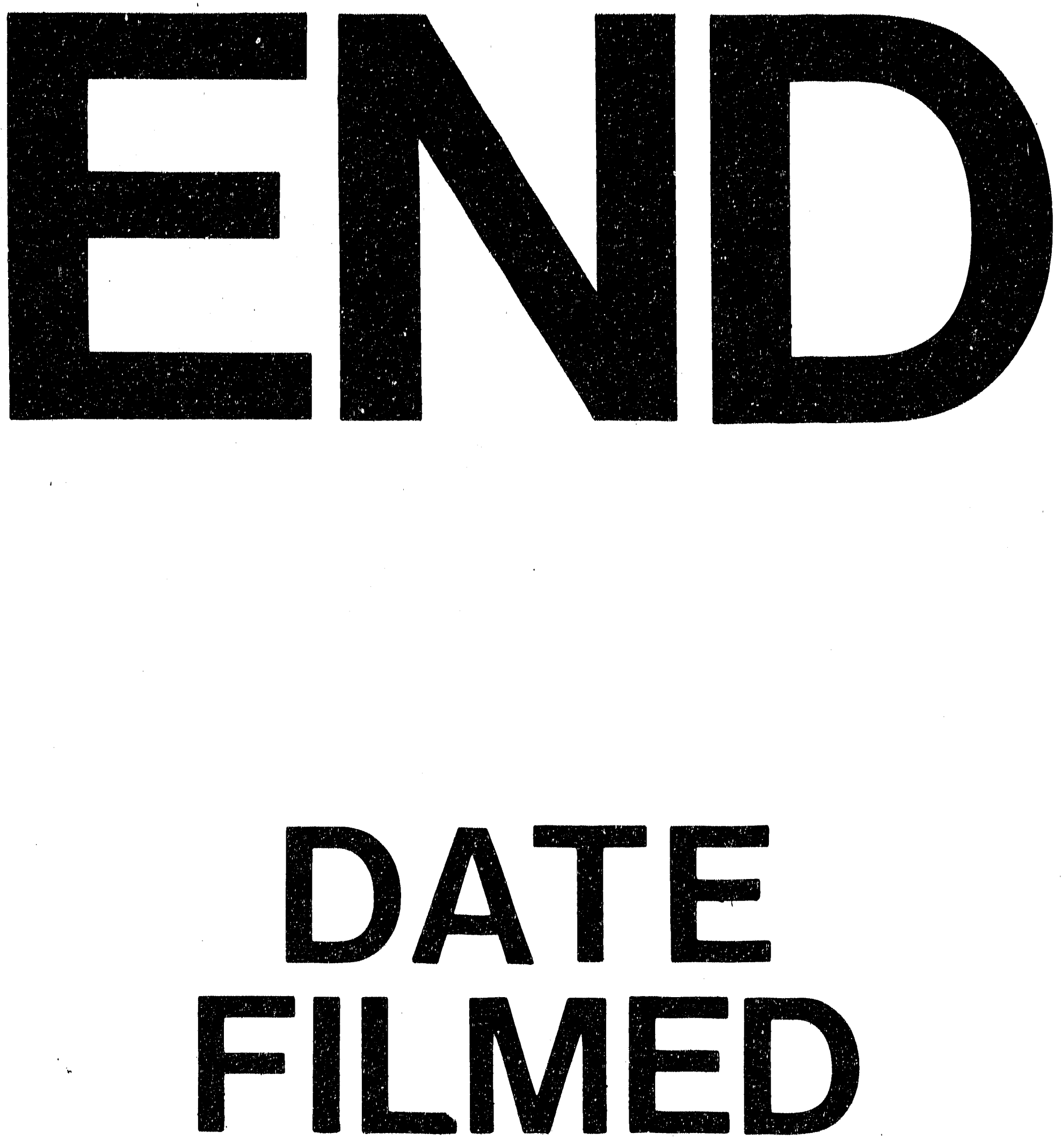

1

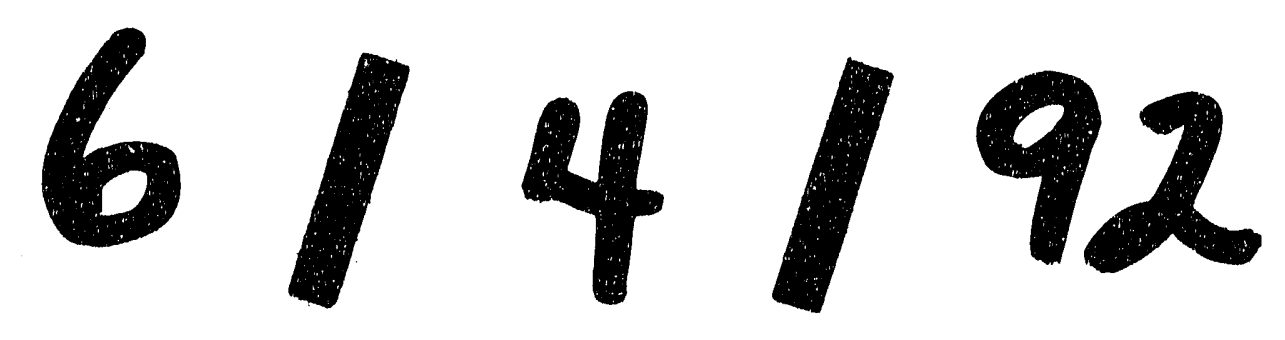


